\title{
High resolution stratigraphy of the Devonian-Carboniferous transitional beds in the Rhenish Mountains
}

\author{
Dieter Korn $^{1}$ \& Dieter Weyer ${ }^{2}$
}

With 26 figures, 1 table, and 4 plates

\begin{abstract}
Summary
The Devonian-Carboniferous Boundary sections at Hasselbachtal, Oese, Apricke, and Ober-Rödinghausen, all located at the northern margin of the Rhenish Mountains, were measured in detail. A semi-quantitative evaluation of the carbonate content and resulting carbonate curves permitted a highly exact correlation of these sections. This result is supported by data on ammonoid records and volcanoclastic horizons. Carbonate fluctuations within the Hangenberg Limestone are regarded as showing a 100000 years cyclicity. A new ammonoid genus Hasselbachia $\mathrm{n}$. gen. and the species Paprothites ruzhencevi $\mathrm{n}$. sp. are described. Among the rugose corals, a new species Hillaxon hassel n. sp., is erected.
\end{abstract}

Key words: Ammonoidea, Rugosa, Devonian-Carboniferous Boundary, Rhenish Mountains, biostratigraphy, lithostratigraphy, correlation.

\section{Zusammenfassung}

Die Devon/Karbon-Grenzprofile Hasselbachtal, Oese, Apricke und Ober-Rödinghausen, alle auf der Nordflanke des Remscheid-Altenaer Sattels gelegen, wurden detailliert aufgenommen. Die halbquantitative Ermittlung des Karbonatgehaltes und daraus resultierenden Karbonatkurven eignen sich für eine sehr genaue Korrelation dieser Profile, die durch Funde von Ammonoideen sowie durch vulkanoklastische Horizonte unterstützt wird. Wechsel im Karbonatgehalt werden als 100000 JahresZyklizität gedeutet. Die neue Ammonoideen-Gattung Hasselbachia n. gen. sowie die Art Paprothites ruzhencevi n. sp. werden beschrieben. Unter den rugosen Korallen wird die neue Art Hillaxon hassel n. sp. errrichtet.

Schlüsselwörter: Ammonoidea, Rugosa, Devon/Karbon-Grenze, Rheinisches Schiefergebirge, Biostratigraphie, Lithostratigraphie, Korrelation.

\section{Introduction}

During the search for a global Devonian-Carboniferous Boundary stratotype, numerous exposures in the vicinity of the hitherto regarded reference section at Ober-Rödinghausen (Jongmans \& Gothan 1937: 7, Paeckelmann \& Schindewolf 1937: 710) at the northern margin of the Rhenish Mountains were intensely investigated (see Korn et al. 1994, Luppold et al. 1994, for further references). The studies focused predominantly on the succession of conodonts (e.g., Ziegler 1969, Ziegler \& Sandberg 1984, Clausen et al. 1987, 1989, Luppold et al. 1994) and ammonoids (e.g., Korn 1984, 1991, 1993), followed by miospores (e.g., Higgs \& Streel 1984, Byvsheva et al.
1984, Higgs et al. 1993), ostracods (e.g., Bless 1983, Bless \& Groos-Uffenorde 1984, G. Becker et al. 1993, G. Becker 1999), and trilobites (e.g., Brauckmann \& Hahn 1984, Brauckmann et al. 1993). The correlation of lithological features played only a subordinate role, and only the Hangenberg Black Shale was used as an index horizon.

Devonian-Carboniferous Boundary sections at the northern margin of the Rhenish Mountains (Fig. 1) emerged as the most important reference sections for the evolution of the latest Devonian and earliest Carboniferous pelagic fauna, particularly for the ammonoids and conodonts (Fig. 2). Sections on the northern flank of the Remscheid-Altena Anticline (Hasselbachtal, Oese,

\footnotetext{
1 Museum für Naturkunde der Humboldt-Universität zu Berlin, Invalidenstraße 43, D-10115 Berlin, Germany. E-mail: dieter.korn@museum.hu-berlin.de

2 Löwestraße 15, D-10249 Berlin, Germany. E-mail: dieter.weyer@t-online.de Received April, accepted July 2003
} 

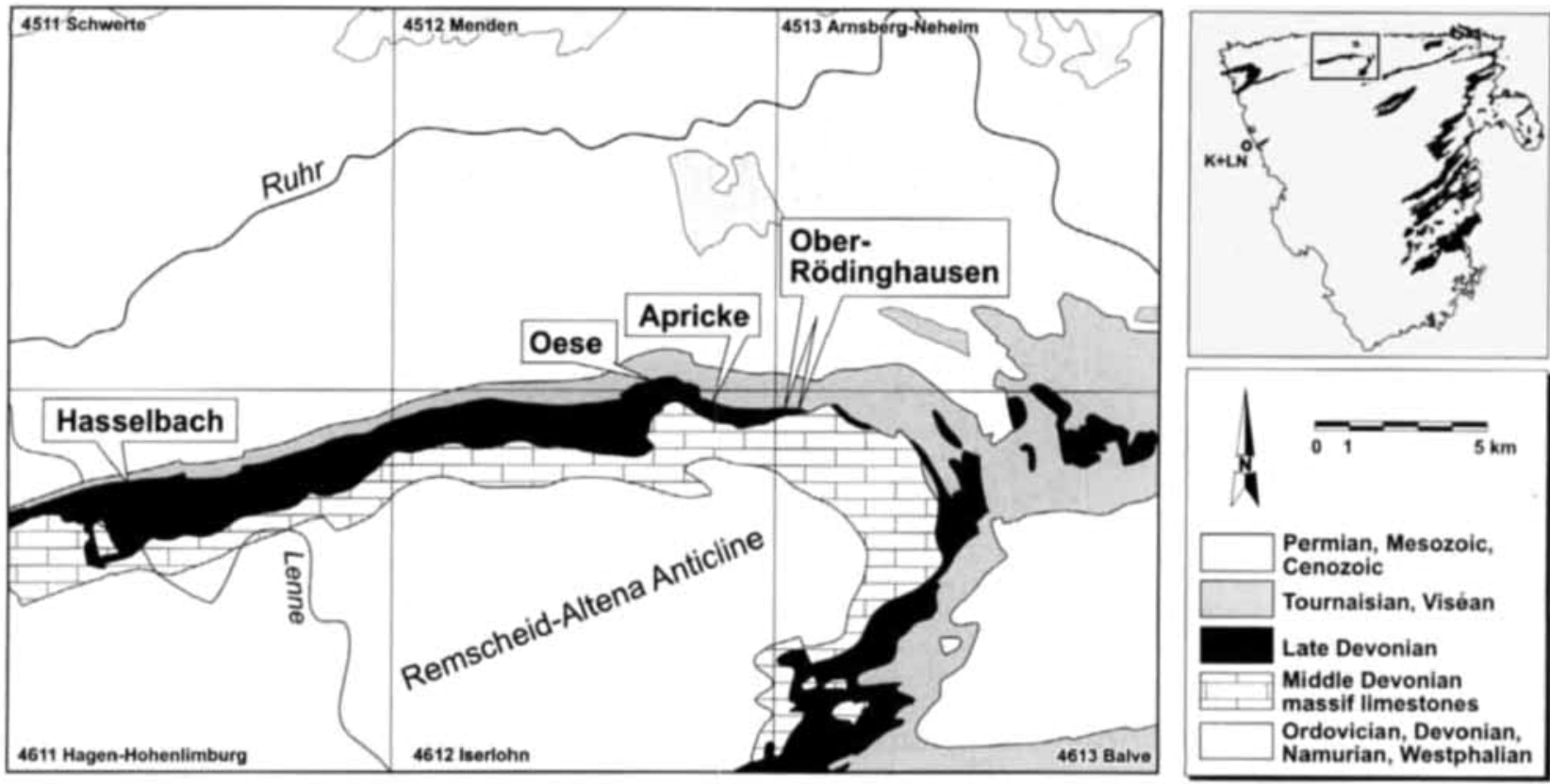

Fig. 1. Geographic position of the investigated sections at the northern flank of the Remscheid-Altena Anticline. [4511-4613 refer to topographic mapsheets $1: 25000]$.

Apricke, Ober-Rödinghausen, Hangenberg, Effenberg, Müssenberg) and the Belecke Anticline (Drewer) have proven to be very important for litho- and biostratigraphic development during this timespan. The global stratotype section and point (GSSP), however, is in the section at La Serre in the Montagne Noire (Paproth et al. 1991).

During the last twenty years, many studies were carried out with the aim of documenting the turnover of pelagic faunas from the Devonian into the Carboniferous (e.g., Price \& House 1984, Korn 1993). The investigation of ammonoid assemblages is rooted in the pioneering and extensive studies by Schindewolf (1937) and Vöhringer (1960) who, in their excellent monographs, outlined an evolutionary change and major break in the ammonoid faunas in the Hangenberg Black Shale.

A highly detailed lithostratigraphic correlation of the Wocklum and Hangenberg Limestones has not been achieved so far. Many sections were measured bed-by-bed (Korn et al. 1994, Luppold et al. 1994), but correlation of sections has mainly been achieved with ammonoid and conodont faunas.

In the following account, a combined correlation of lithostratigraphy (primarily based on fluctuations in the carbonate content) and ammonoid biostratigraphy will be presented. In a revisit to the Devonian-Carboniferous Boundary sections of the Rhenish Mountains (Fig. 1), at- tention was focused in particular on developing a precise lithological record as used in parallel studies in Thuringia (Bartzsch \& Weyer 1982, Bartzsch et al. 1999, 2002). The sections were measured at the centimetre scale, and several tuffites or metabentonites were discovered. Correlation of lithological and palaeontological features led to a high resolution stratigraphy for those latest Devonian and earliest Carboniferous successions.

\section{The sections under study}

\section{Hasselbachtal}

Location: Northern and southern (right and left) banks of the Hassel rivulet; $1.5 \mathrm{~km}$ eastnortheast of Hagen-Reh.

Previous investigations: The auxiliary stratotype section for the Devonian-Carboniferous Boundary was first mentioned by Schmidt (1924), who published a brief description of the rock succession. He distinguished the "DasbergSchichten" (i.e. Dasberg and Wocklum Limestones), "Hangenberg-Schiefer" (including the Hangenberg Black Shale at the base), and the "Hangenberg-Kalk". Only 50 years later, the exposure attracted the further interest of stratigraphers, when Groos-Uffenorde \& Uffenorde (1974) re-investigated and sampled the Hangenberg Limestone for conodonts and ostracods. 


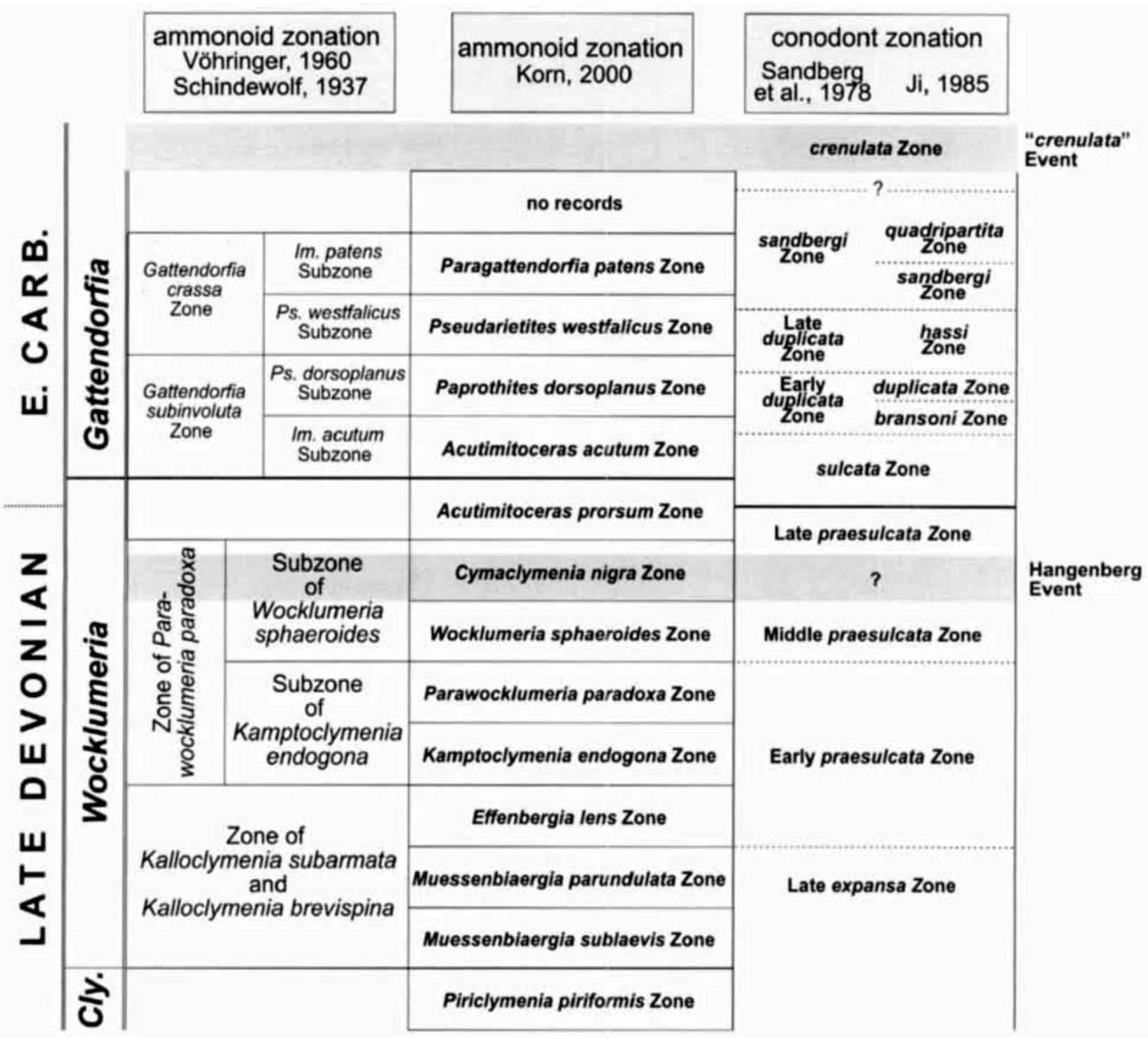

Fig. 2. Ammonoid and conodont stratigraphy near the Devonian-Carboniferous Boundary.

One of the results of their study was the discovery of a fauna with Siphonodella sulcata (Huddle, 1934) in the basalmost limestone bed (bed 84; their sample 956).

During the search for a Devonian-Carboniferous Boundary stratotype, the section on the right (northern) bank was re-examined several times. In a multidisciplinary study, Becker et al. (1984) gave a first detailed description of the Hangenberg Limestone and Hangenberg Shale, with references to conodont and ammonoid occurrences. The faunal list presented there was supplemented by Becker (1985).

A first monographic description of the Wocklum Limestone was published by R. T. Becker (1988). He presented columnar sections of a portion of the Wocklum Limestone (measured on the left bank of the stream) and the Hangenberg Limestone. From the latter (beds 55, 57, and 78), he mentioned three ammonoid specimens, that belong to the genera Acutimitoceras and Eocanites.

Becker's error in postulating an overlap in the occurrences of the genera Kalloclymenia and Wocklumeria was corrected by Luppold et al. (1994), who demonstrated that the Wocklum Limestone ranges much higher than proposed by R. T. Becker. These authors showed that above the top of Becker's section a further 2.50 metres of nodular limestones followed, and discovered that records of Wocklumeria sphaeroides (Richter, 1848) and Parawocklumeria paradoxa (Wedekind, 1918) as cited by R.T. Becker in reality referred to surface-collected specimens (R. T. Becker, pers. comm.). In situ collected Wocklumeria sphaeroides occur immediately below the Hangenberg Black Shale (Luppold et al. 1994). 


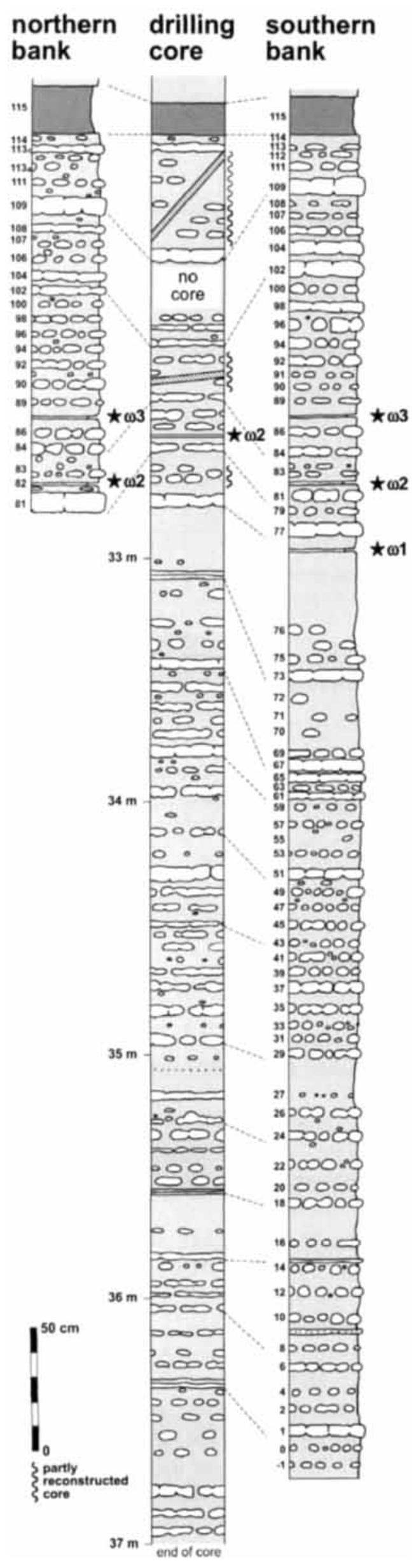

The Hangenberg Shale has proven rather poor in ammonoids. Schmidt (1924) mentioned a marly fossiliferous portion ("Steinmergelbank") at the top of the Hangenberg Shale, and R. T. Becker (1988) recorded a few poorly preserved ammonoid specimens (Acutimitoceras sp.) from bed 85 . Investigation of this upper portion of the Hangenberg Shale yielded more crushed specimens of the genus Acutimitoceras. Intensive collecting by DW in 1993 and 1994 yielded first corals (Weyer 1995, 2001); the chonetid brachiopods were studied by Afanas'eva (2002). A detailed lithostratigraphy of the latest Famennian, including the volcanic ash layers of the Parawocklumeria paradoxa Zone, was published (Weyer 1995: fig. 1).

Additional information about the section, including a revised lithological column of the Wocklum Limestone was provided by R.T. Becker (1996). From this formation, he reported a number of ammonoid specimens, that permitted subdivision of the unit into several zones.

Description of the section: The exposure suffers at present from very poor outcrop conditions; the Devonian-Carboniferous Boundary strata can only be studied after intensive trenching. The section on the southern river bank (which was measured by R. T. Becker 1988 and Luppold et al. 1994) is now almost completely covered by scree and no longer accessible. In $1988,5.40 \mathrm{~m}$ of grey shales with interbedded nodular limestones were exposed. Three metabentonite horizons (named herein $\omega 1, \omega 2$, and $\omega 3$ in ascending order) were discovered 1.68 , 1.41 , and $1.14 \mathrm{~m}$ below the top of the Wocklum Limestone (Figs 3, 4).

On the northern bank of the Hassel stream, the topmost $1.50 \mathrm{~m}$ of the Wocklum Limestone can be studied in a low outcrop, which extends into the stream. The section is composed of grey nodular limestones with prominent shaly inter-

Fig. 3. Columnar sections of the Wocklum Limestone in the Hasselbach outcrops. Northern bank (Hasselbach N) after Weyer (1995) and Becker (1996); Hasselbach 1/1987 drilling core measured in 1993 by Weyer; southern bank (Hasselbach S) after Luppold et al. (1994; upper part, corrected using measurements in 1988 by Korn and Paproth) and measurements in 1994 by Weyer (lower part; following Becker 1988). Ammonoid ranges after Becker 1996. Metabentonite horizons $(\omega 1, \omega 2, \omega 3)$ indicated by an asterisk. 


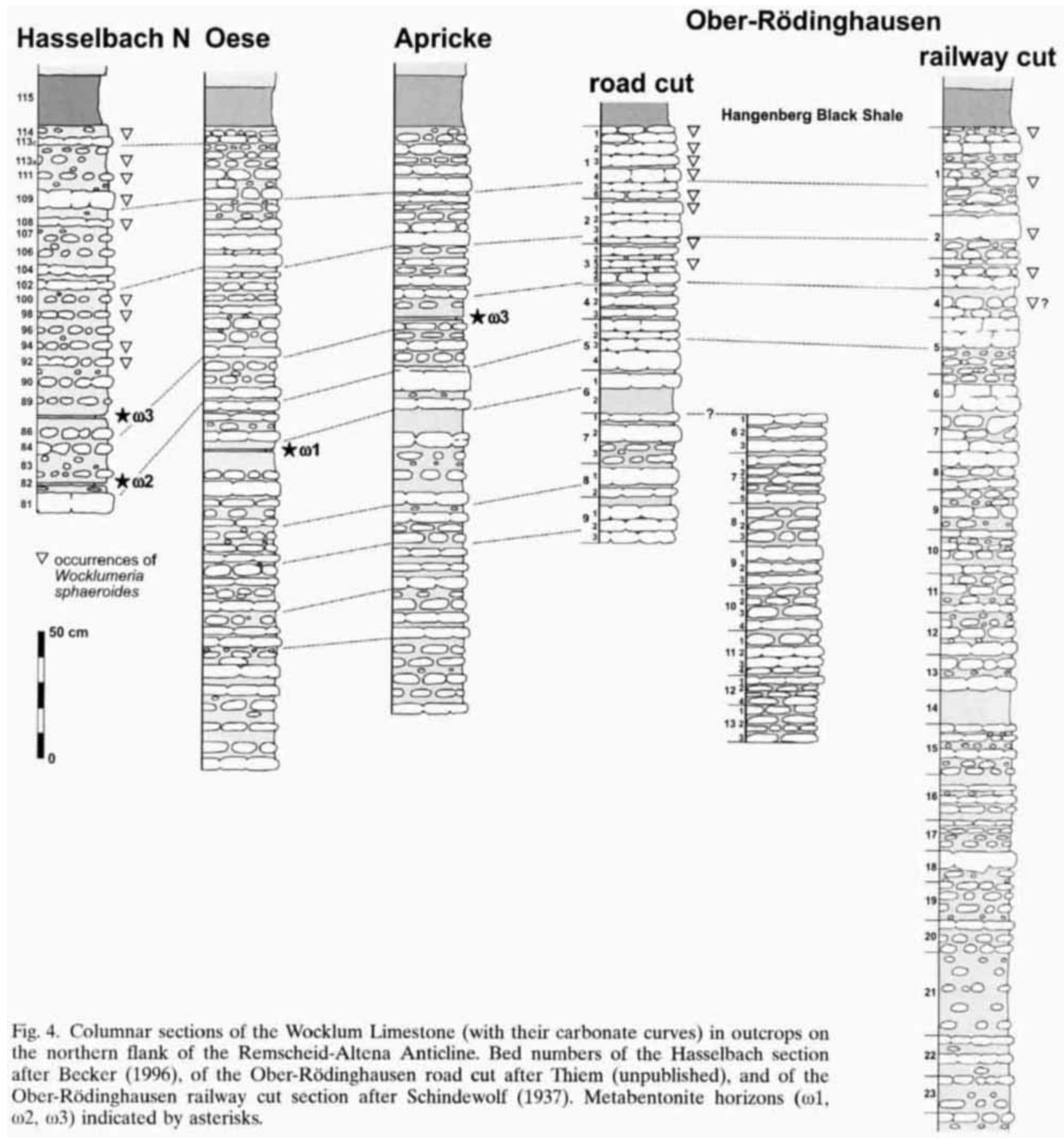

beds. Two thin metabentonite horizons ( $\omega 2$ and $\omega 3)$ were discovered 1.42 and $1.15 \mathrm{~m}$ below the top of this unit. Some late Famennian Rugosa from the northern and southern outcrops will be described here.

The Wocklum Limestone is overlain by the Hangenberg Black Shale which has 0.20 metres in thickness, and is followed by $5.60 \mathrm{~m}$ of the Hangenberg Shale. This is largely a silty shale with abundant mica flakes and numerous specimens of Guerichia sp. The topmost $0.65 \mathrm{~m}$ are almost free of mica and silt; instead, a low carbonate content is detectable. These shales yielded crushed ammonoids and gastropods (Luppold et al. 1994). The crushed specimen of "Acutimitoceras acutum", figured by Korn in Luppold et al. (1994: fig. 4A) has been further prepared. It is completely involute with rather coarse, biconvex growth lines. Assignment to a particular species is difficult, and the determination adopted here is Acutimitoceras sp.

The following Hangenberg Limestone has a thickness of $2.60 \mathrm{~m}$ and a lithology that is similar to that of the Wocklum Limestone (Figs 5, 6). Three metabentonite horizons (named herein as $\alpha 1, \alpha 2$, and $\alpha 3$ in ascending order) were discovered $0.43,1.00$, and 1.96 metres above the base of the unit. The unit begins with a turbiditic, 


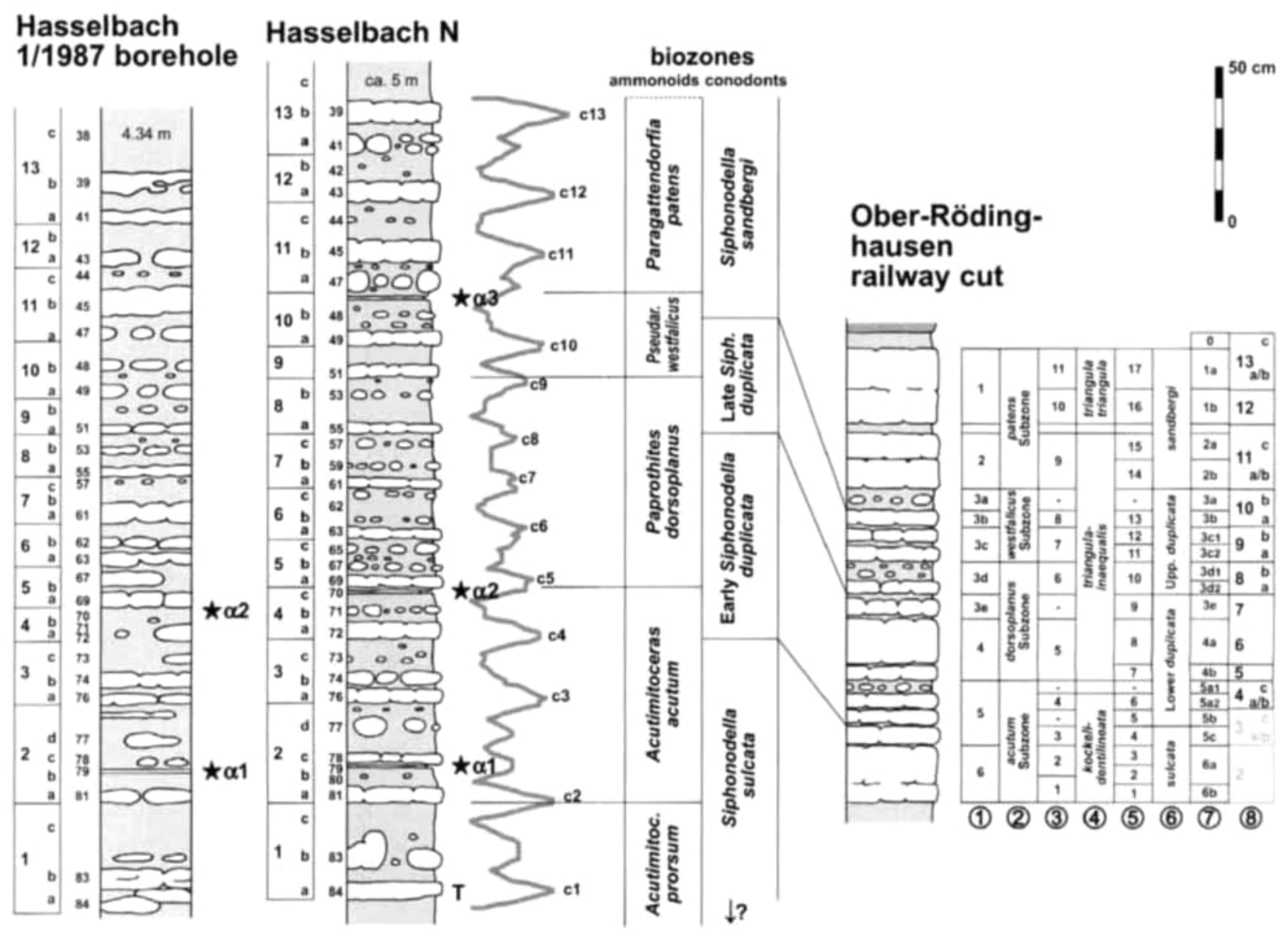

Fig. 5 Columnar sections of the two outcrops of the Hangenberg Limestone at Hasselbach (Hasselbach $\mathrm{N}$ section with carbonate curve) and their comparison with the outcrop in the railway cut of Ober-Rödinghausen. Correlation by means of lithological features and ammonoid distribution. Metabentonite horizons $(\alpha 1, \alpha 2, \alpha 3)$ indicated by asterisks, turbiditic beds indicated by a $T$. At the right side of the Ober-Rödinghausen profile, the various terminologies of lithology and biostratigraphy are shown (1 - bed numbers of Vöhringer 1960; 2 - ammonoid zones after Vöhringer 1960; 3 - sample numbers of Voges 1959, 1960; 4 - conodont stratigraphy after Voges 1959, 1960:5 - sample numbers of Ziegler 1971; 6 - conodont stratigraphy after Ziegler 1971; 7 - bed numbers as used in this paper; 8 - correlated bed numbers as used in this paper.

finely laminated limestone bed of 0.06 metres in thickness (bed 84), which is almost devoid of fossils. However, it occasionally contains fossiliferous nodules, which yielded a basalmost Carboniferous conodont fauna with Siphonodella sulcata (Huddle, 1934) (Groos-Uffenorde \& Uffenorde 1974, Kürschner et al. 1993). Above this bed, Nicimitoceras cf. carinatum (Schmidt, 1925) was discovered, providing evidence that at least parts of the famous Stockum Limestone fauna (Korn 1984; Acutimitoceras prorsum Zone) belong to the Carboniferous, as proposed by Becker \& Paproth (1993) and Becker (1996).

From the Hangenberg Limestone, DW collected a suite of more than 140 ammonoid specimens (Fig. 7), of which some are described and illustrated in the palaeontological section of this article (see cross-sections in figure 14 and photographic illustrations in plates 1 and 2). The corals (pl. 4) are typical Rugosa species of the "Gattendorfia Stufe" of German localities.
An additional section was obtained by a drilling (borehole Hasselbach 1/1987) made by the Bundesanstalt für Geowissenschaften und Rohstoffe (BGR). The core has some distorted parts, but allows precise study of the lithological succession. Near the top of the Wocklum Limestone, two faults interrupt the sequence, and only one of the metabentonites $(\omega 2)$ is preserved (Fig. 3). The Hangenberg Limestone in the drill section closely resembles that of the surface outcrop (Fig. 5). It is overlain by $4.34 \mathrm{~m}$ of dark grey claystones (ostracod shales) of the upper Siphonodella sandbergi Zone, with some pseudoplanctonic and benthic macrofossils, mostly bivalves [Guerichia venustiformis (Sadykov, 1962 and Guerichia aff. mariannae (Chernychev, 1941) sensu Sadykov 1962], some trilobites, small lingulid and articulate brachiopods (?athyrid), one rugose coral. This part of the Hangenberg Formation and its entomozoid fauna were described by Groos-Uffenorde \& Uffenorde (1974) from now 


\section{Hasselbach $\mathbf{N}$}

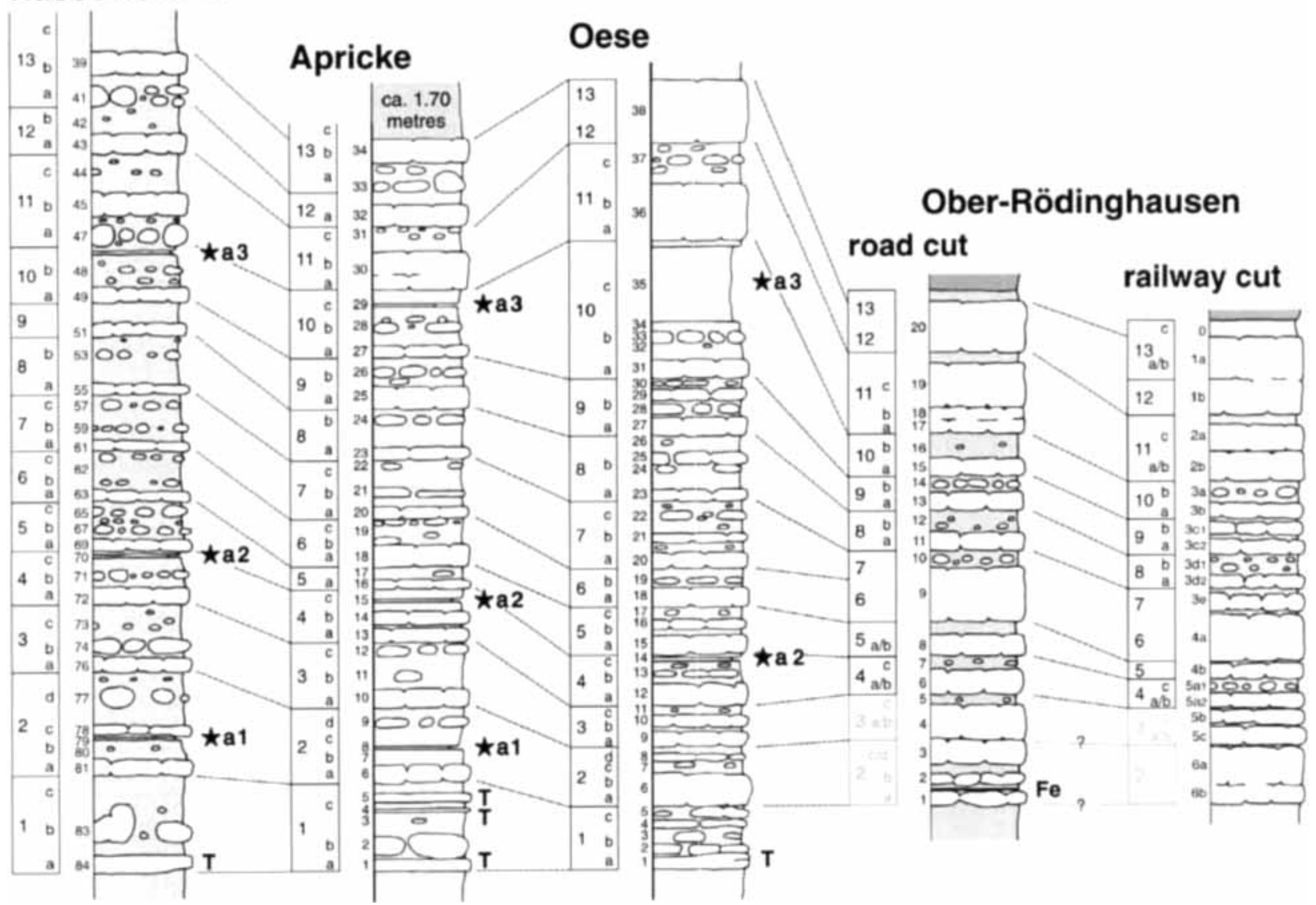

Fig. 6. Columnar sections of the Hangenberg Limestone in outcrops on the northern flank of the Remscheid-Altena Anticline (arrangement according to facies distribution, not to geography). Bed numbering of the Hasselbach section after Becker et al. (1984) and of the Ober-Rödinghausen railway cut after Vöhringer (1960). Metabentonite horizons $(\alpha 1, \alpha 2, \alpha 3)$ indicated by asterisks, turbiditic beds indicated by a $\mathrm{T}$. At the left margin of each section, a unified bed numbering is introduced, based on lithological correlation.

inaccessible Hasselbach surface outcrops, with an estimated thickness of approximately five metres. Then follow the anoxic Lower Alum Shales ( $\mathrm{Si}$ phonodella crenulata Zone).

\section{Oese}

Location: A combination of three outcrops (road cuts and a small abandoned quarry) along the B7 road between Hemer and Menden, opposite the railway stop of Becke-Oese, permits the study of an almost complete section running from Late Devonian shales and nodular limestones up into the Middle Tournaisian alum shales and cherts.

Previous investigations: The section was already known to Denckmann (1901), and Schmidt (1924) provided an overview of its lithological subdivision. Ziegler (1962) then investigated the section because of its Late Devonian conodont succession; he introduced the first stratigraphic scheme for the beds, extending from the Annulata Black Shale to the top of the Wocklum Limestone, and ranging from the velifera Zone up to the upper costatus Zone.

Later, the Hangenberg Limestone was measured and studied by Eva Paproth. She sampled this unit for ammonoid faunas, and her collections were identified by Kullmann (in Paproth \& Streel 1982). Keupp \& Kompa (1984) studied the Hangenberg Sandstone and postulated that the sediments originate from a source in the South. A re-examination of the exposure (Luppold et al. 1994), including conodont sampling from the basal Hangenberg Limestone, showed that this section is remarkably similar to the neighbouring sections at Hasselbachtal and Apricke.

Description of the section: The middle to late Famennian is represented in the exposure along the road-cut south-west of the old quarry. Sandstones (in the lower part) as well as shales with thin nodular limestone horizons are the main lithological components of the section. The topmost $24 \mathrm{~m}$ (Dasberg and Wocklum Lime- 


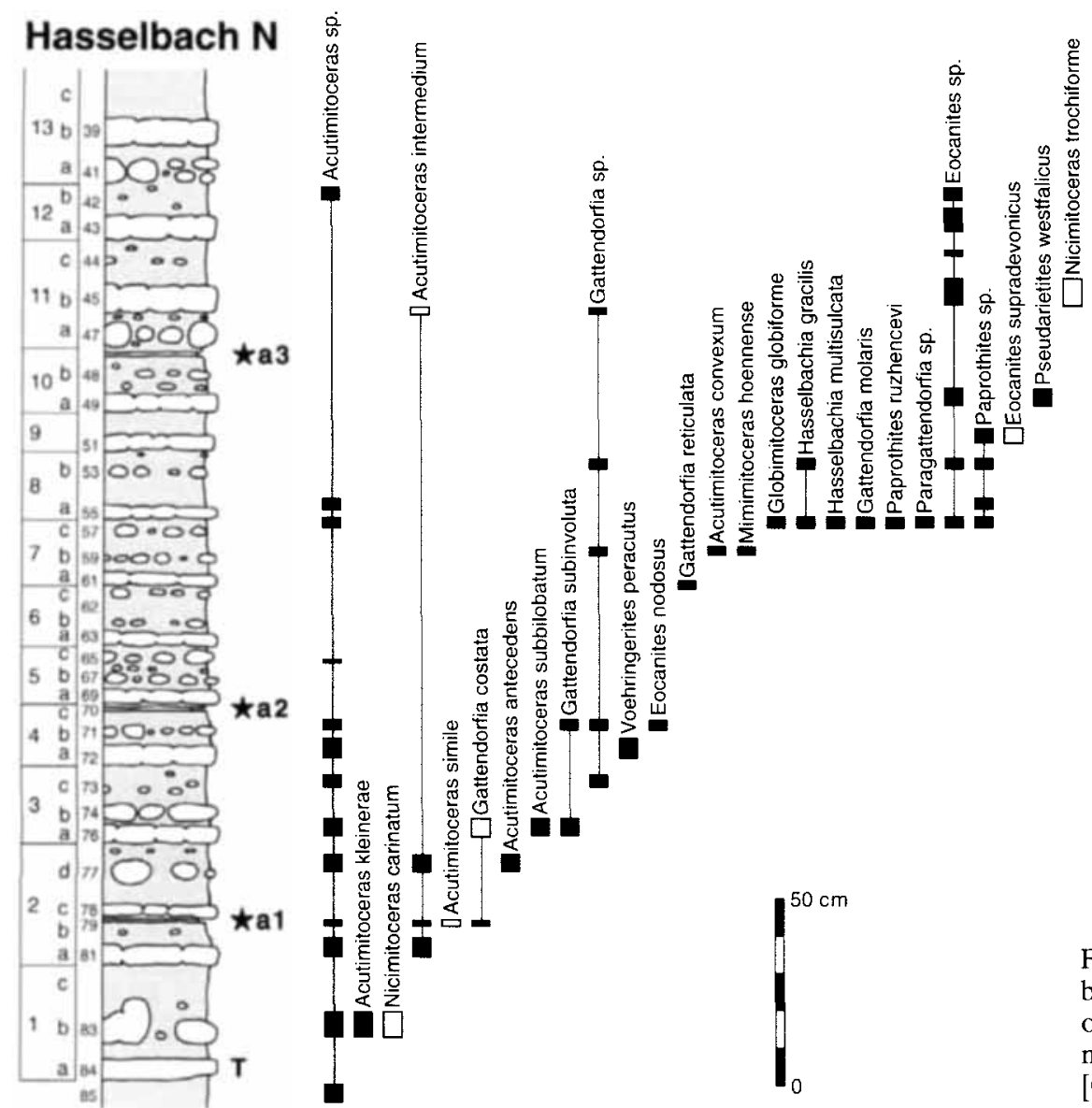

Fig. 7. Columnar section of the Hangenberg Limestone in the Hasselbach $\mathrm{N}$ outcrop with the distribution of ammonoid species recorded from this outcrop. [Open bars refer to ef-determination] stones; lithological column published by Ziegler 1962) consist of reddish and greyish shales in which nodular limestone horizons are intercalated. Toward the top of the section an increase in carbonate material can be recognised (Fig. 4).

The Wocklum Limestone is completely exposed, but its base, which is biostratigraphically defined (Schindewolf 1937), cannot be located because of low fossil content. The rugose coral Gorizdronia sp. A (Fig. 25) was collected by U. Lemke in the upper part of the Wocklum Limestone. The Hangenberg Black Shale is $0.15 \mathrm{~m}$ in thickness and yielded numerous completely crushed ammonoids (probably Postclymenia evoluta Schmidt, 1924). In the road-cut, approximately $15 \mathrm{~m}$ of silty Hangenberg Shale lie above the black shale.

The continuation of the section is found in the small abandoned quarry beside the road, where an intercalation of approximately $12 \mathrm{~m}$ of bedded, silty to coarse-grained Hangenberg Sandstone is exposed. These sandstones end rather abruptly and are overlain by the Hangenberg Limestone, of which the majority is exposed in the western quarry wall. It is mainly composed of grey nodular limestones, but its base consists of a platy limestone bed with an internal organisation typical of a distal turbidite. Its graded base is rich in mica.

The Hangenberg Limestone is also visible in the road-cut north-east of the old quarry, where the higher portion is better accessible than in the quarry. As in the Hasselbachtal section, volcanoclastic horizons within the unit could be identified (Fig. 6), of which the highest is very prominent with a thickness of $0.23 \mathrm{~m}$. During our reinvestigation, more than 110 ammonoid specimens were collected from several levels (Fig. 8, Pl. 2). The "index coral" Hebukophyllum priscum (Münster, 1840) also occurs (see Fig. 24). The Lower Alum Shale horizon follows above the Hangenberg Limestone.

\section{Apricke}

Location: Several Devonian-Carboniferous Boundary sections were studied in the vicinity of Apricke and Riemke, but most of them were only temporarily accessible. A single permanent outcrop can be found in the little stream one kilometre North of Apricke; here, on both banks, the Wocklum and Hangenberg Limestones, separated by $5 \mathrm{~m}$ of shales are exposed. 

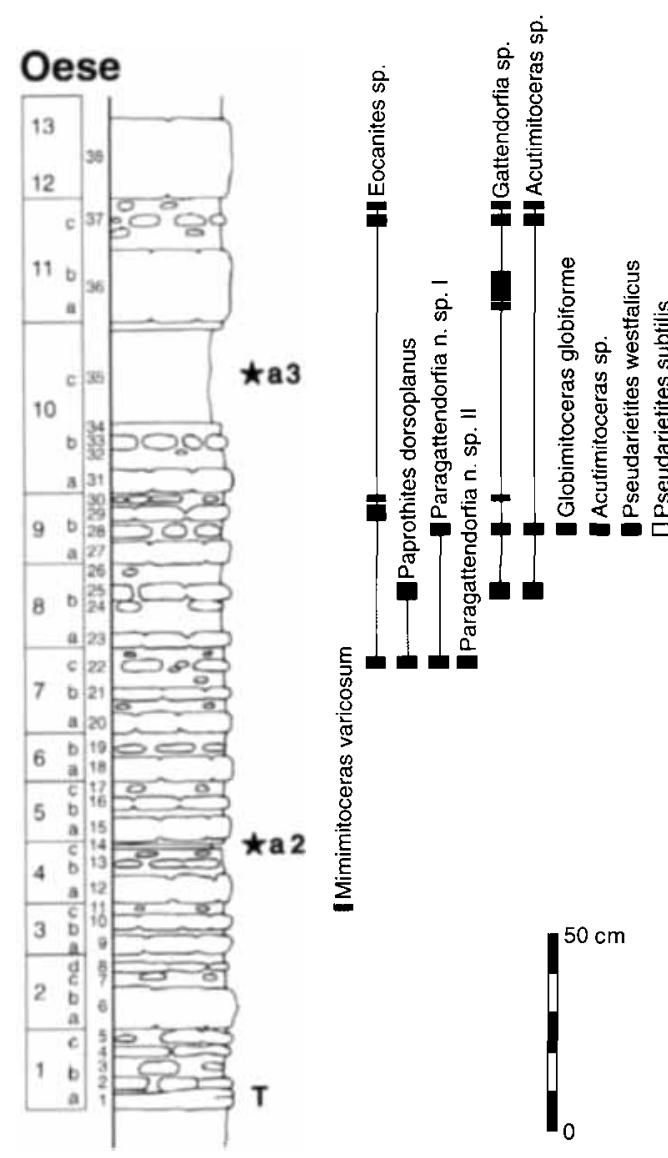

Fig. 8. Columnar section of the Hangenberg Limestone in the Oese outcrop with the distribution of ammonoid species recorded from this outcrop. [Open bars refer to cf-determination]
Previous investigations: The section was already briefly described by Schmidt (1924) and re-investigated by Paproth (Paproth \& Streel 1982). The outcrop turned out to be relatively poor in macrofossils; only the highest portion of the Wocklum Limestone yielded ammonoids (Luppold et al. 1994) and trilobites (Feist et al. 2000). A few specimens of ammonoids were found in the basal Hangenberg Limestone.

Description of the section: The Wocklum Limestone is strikingly similar to that in the Hasselbachtal and Oese sections (Fig. 4), and contains a metabentonite horizon $0.75 \mathrm{~m}$ below the top. The Hangenberg Black Shale is $0.20 \mathrm{~m}$ thick and overlain by $4.80 \mathrm{~m}$ of silty Hangenberg Shale. As in the Hassel stream section, the basal bed of the Hangenberg Limestone is a turbiditic and slightly laminated, non-nodular bed. Two additional thin turbidite beds occur near the base of the section (beds 4 and 5). The Hangenberg Limestone has a total thickness of $2.30 \mathrm{~m}$; three metabentonite horizons were found in this unit $0.40,0.85$, and $1.80 \mathrm{~m}$ respectively above the base (index beds $\alpha 1, \alpha 2$, and $\alpha 3$ ).

Conodont samples from the basalmost part of the Hangenberg Limestone showed that Siphonodella sulcata occurs in bed 6 (Luppold et al. 1994); they contain also some "silicified" ostra- cods of the Thuringian ecotype. It is the same fauna as described for the first time by Gründel (1961) from the Pfaffenberg Member (of the Gleitsch Formation) near Saalfeld in Thuringia. Except for the Drewer locality (G. Becker et al. 1993), such psychrosphaeric communities are rarely found and dissolved in the Rhenish Mountains due to missing "silicification", but the fauna is present there everywhere, too, as proved by thin sections ( $\mathrm{Pl}$. 4: 15, 16). The ammonoid content is relatively poor in comparison to the Oese section, although bed 2 yielded several specimens of Nicimitoceras cf. carinatum and Acutimitoceras sp. This is further evidence of the presence of the Acutimitoceras prorsum Zone at the base of the Hangenberg Limestone.

\section{Ober-Rödinghausen, railway cut}

Location: This famous outcrop is located along the railway track between Menden and Balve, at the western margin of the big cement works of Ober-Rödinghausen.

Previous investigations: This highly fossiliferous exposure is one of the best-studied and best-known Devonian-Carboniferous Boundary sections world-wide. It was first described by 
Schmidt (1924), who already noted rather rich faunas from the Wocklum and Hangenberg Limestones, and erected a number of new ammonoid species.

In an outstanding study, Schindewolf (1937) investigated the Wocklum Limestone in a bedby-bed manner; he separated 22 strata within the $3.72 \mathrm{~m}$ thick rock succession named by him as the Wocklumer Schichten. Within this unit he discriminated three biostratigraphic units. In total, he mentioned 70 species of cephalopods.

Schindewolf also investigated the Hangenberg Limestone, but almost the entire material collected was destroyed in World War II, except for the trilobites (Richter \& Richter 1951), the bivalves (Paul 1954), and some corals and brachiopods. Therefore, he engaged Vöhringer (1960) to re-examine this rock unit. The result was a detailed description of more than 50 goniatite species and a subdivision of the Hangenberg Limestone into four biostratigraphic units.

Voges $(1959,1960)$ sampled the Hangenberg Limestone for conodonts and arrived at a subdivision scheme with three zones mainly based on species of the genus "Pseudopolygnathus" (now Weyerognathus Dzik, 1997). Later investigations of the outcrop focused on the conodonts (Ziegler 1971) and miospores (Paproth \& Streel 1970, Higgs \& Streel 1984). These more recent studies showed that there is a stratigraphic gap at the base of the Hangenberg Limestone (late praesulcata conodont Zone; VI Zone in terms of miospores; prorsum Zone in ammonoids). The basal limestone bed $6 \mathrm{~b}$ (Fig. 5 , thickness $7 \mathrm{~cm}$. DW collections) already yielded Siphonodella sulcata (Huddle, 1934) and Gattendorfia sp. (see also Luppold et al. 1994: 27). An opposite information of Walliser \& Alberti (1979: 79) about this level, proposing close faunistic relationships to the Stockum Limestone (Protognathodus fauna) is not correct; it was based mainly on an interpretation of the trilobite community with Belgibole abruptirhachis (Richter \& Richter. 1919), now well known within the Siphonodella sulcata Zone (Flajs \& Feist 1988). In contrast to the majority of German sections of the basal "Gattendorfia Stufe" in the Rhenish, Thuringian and Upper Franconian Mountains, where the presence of the Acutimitoceras prorsum Zone (together with a Protognathodus conodont fauna) is now a standard, just the classical reference section of the Ober-Rödinghausen railway cut offers a hiatus. Steenwinkel (1984) was able to demonstrate, in a drilling core section from the immediate neighbourhood of the railway cutting, that there is a thin horizon at the base of the unit that contains reworked material. She interpreted the gap at the base of the Hangenberg Limestone as an erosional break.

The Ober-Rödinghausen railway cut section is also important for the presence of other invertebrate faunal groups (additional to ammonoid, conodont, trilobite, and miospore index fossils); there are descriptions of latest Famennian and earliest Tournaisian corals (Weyer 1981, 1995, 2001). brachiopods (Weyer 1972a, Afanas'eva 2002), and crinoids (Weyer 1965, 1979).

Description of the section: The section begins with red shales which contain numerous thin limestone nodules ("Fossley" of earlier authors) of middle Famennian age. Toward the top, the colour changes to grey, as the carbonate content increases. There is a striking, $0.16 \mathrm{~m}$ thick compact limestone bed located $5.20 \mathrm{~m}$ below the top of the Late Devonian carbonate section. It is overlain by a series of alternating shales and nodular limestones, which largely represent the Wocklum Limestone. The carbonate content increases markedly within this stratigraphic interval, and the succession appears to be truncated by the Hangenberg Black Shale, which is $0.15 \mathrm{~m}$ in thickness (Figs 4, 9).

According to Schindewolf (1937), the "Wocklumeria Stufe" (which is coeval with the Wocklum Limestone) has a total thickness of $3.72 \mathrm{~m}$ (his beds 1-22). The lower boundary of the Wocklum Limestone was drawn at the first occurrence of a questionable specimen of "Kalloclymenia brevispina" (probably a Sphenoclymenia). Ammonoids typical of the underlying "Clymenia Stufe" have not been recorded, thus it might be that this boundary only reflects collection circumstances. The first detailed lithostratigraphic column of the section is presented here in figure 4.

Above the Wocklum Limestone, $0.15 \mathrm{~m}$ of Hangenberg Black Shale and $6.30 \mathrm{~m}$ of Hangenberg Shales follow; they are rich in mica particularly in the middle part. Their upper portion is fine-grained and contains crushed goniatites of the genus Acutimitoceras (Paproth \& Streel 1970, Luppold et al. 1994).

The Hangenberg Limestone has a thickness of $1.50 \mathrm{~m}$ and, like the upper portion of the Wocklum Limestone, is composed of nodular limestone with thin shaly interbeddings (Figs 5, 6). Vöhringer (1960) separated six beds within this unit, of which bed 3 was further subdivided into five units. We subdivided also the other beds 
(Fig. 5). Bed 3a was not sampled for conodonts by Voges (1960) and Ziegler (1971); here we found the first Siphonodella sandbergi Klapper, 1966 together with still many Pseudorietites westfalicus Schmidt, 1924 (see emended correlation of ammonoid and conodont zone in Figs 2, 5).

The Hangenberg Limestone is followed above by five centimetres of grey shales with conodontite bedding planes and some trilobites and bivalves (Guerichia) (bed 0 ), which are overlain by the Lower Alum Shale Formation, which becomes successively replaced by black lydites.

\section{Ober-Rödinghausen, road cut}

Location: The road cut section is located only $200 \mathrm{~m}$ east of the railway cutting on the eastern side of the Hönne Valley. It is a low exposure that suffers from overgrowth by vegetation.

Previous investigations: The first extensive description of this section was given by Ziegler (1962), who sampled the Upper Devonian sections for conodonts. At the same time, the Wocklum Limestone was intensively sampled for ammonoids by the doctorate student Thiem (Tübingen). He collected 3000 specimens of ammonoids, but this investigation was never published. In 1978, DK re-investigated this portion of the section and collected approximately 500 ammonoid specimens.

Description of the section: The section of the Wocklum and Hangenberg Limestones closely resembles that in the railway cut succession, and only minor differences can be seen (Figs 4, 6). The main difference between the two concerns the Hangenberg Shale: In the road cut section this unit is approximately 15 metres thick, with the intercalation of thick-bedded, coarse-grained sandstone beds (Hangenberg Sandstone).

\section{Stratigraphy of the sections}

\section{Methods}

The five sections were measured at the centimetre scale. For the lithological correlation of the successions, mainly composed of nodular limestones and interbedded claystone horizons, carbonate curves were generated for each section. For this analysis, six different lithologies (with decreasing carbonate content) were discriminated:
- pure platy limestones with even bedding surfaces

- nodular limestone beds poor in clay content

- limestone nodules (densely arranged) in shales

- isolated limestone nodules in shales

- shales with rare, small limestone nodules

- pure shales and metabentonites

To estimate the carbonate content, values, ranging from 5 (platy limestones) to 0 (pure shales and metabentonites) were assigned to these lithologies. Using these values, graphs were computed for each section. In the subsequent analysis, the rhythmic limestone-shale interbeddings could be correlated.

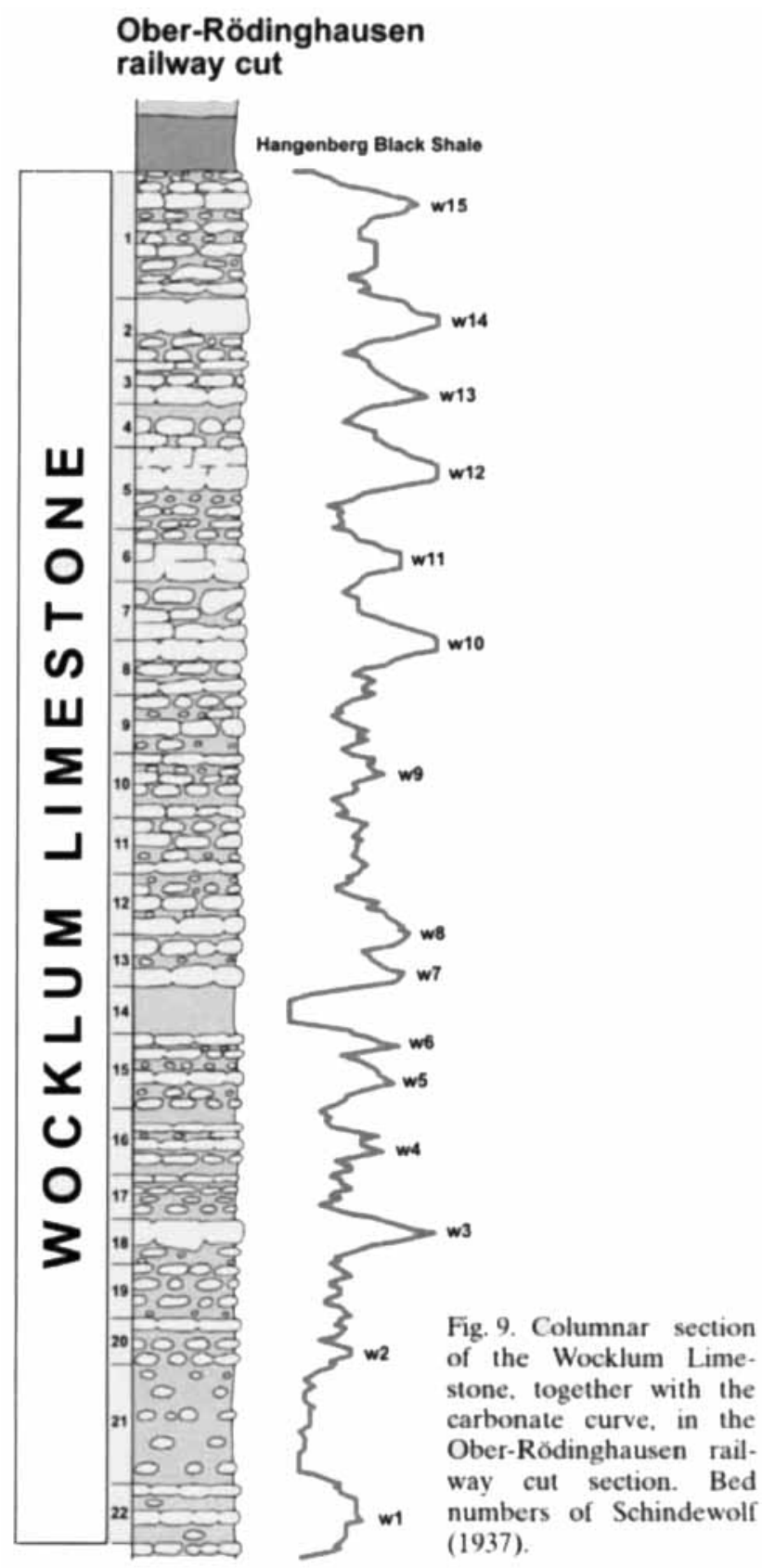




\section{Correlations}

Wocklum Limestone: For the Wocklum Limestone, the famous and well-studied railway cutting section near Ober-Rödinghausen (Fig. 9) can serve as a standard. There is a more or less gradual increase in the carbonate content observable within this rock unit, and 15 carbonate peaks can be recognised (w1-w15). These peaks in the curve reflect nodular limestone beds, which in some cases cluster together. They show a distinct pattern in their irregular distribution, but despite this pattern there are alternating periods with lower and higher carbonate deposition and only an inconspicuous periodicity is visible.

The carbonate concentration curves can, in some cases, be perfectly correlated between neighbouring sections (Fig. 10). In the lower portion of the Wocklum Limestone, the analysis and correlation of sections is difficult because of the rarity of index fossils in most sections apart from that at Ober-Rödinghausen. Another difficulty is the rather uniform sedimentation within parts of this rock unit. Some thicker (up to $0.20 \mathrm{~m}$ ) claystone horizons also help to correlate the sections.

Fluctuations in the carbonate/clay ratios within the succession allow the discrimination of three lithological sub-units in the Wocklum Limestone of the Ober-Rödinghausen section.

Hangenberg Limestone: The sections of the Hangenberg Limestone are easier to correlate because they show a clearer lithological subdivision. A close similarity in the organisation of the basal bed of the Hangenberg limestone at Hasselbachtal, Oese, and Apricke is taken as evidence for an isochronous horizon. Certainly, this horizon is missing in the Ober-Rödinghausen section due to a sedimentary gap (Steenwinkel 1984).

For these reasons, the successions in the localities at Hasselbach, Apricke, and Oese provide

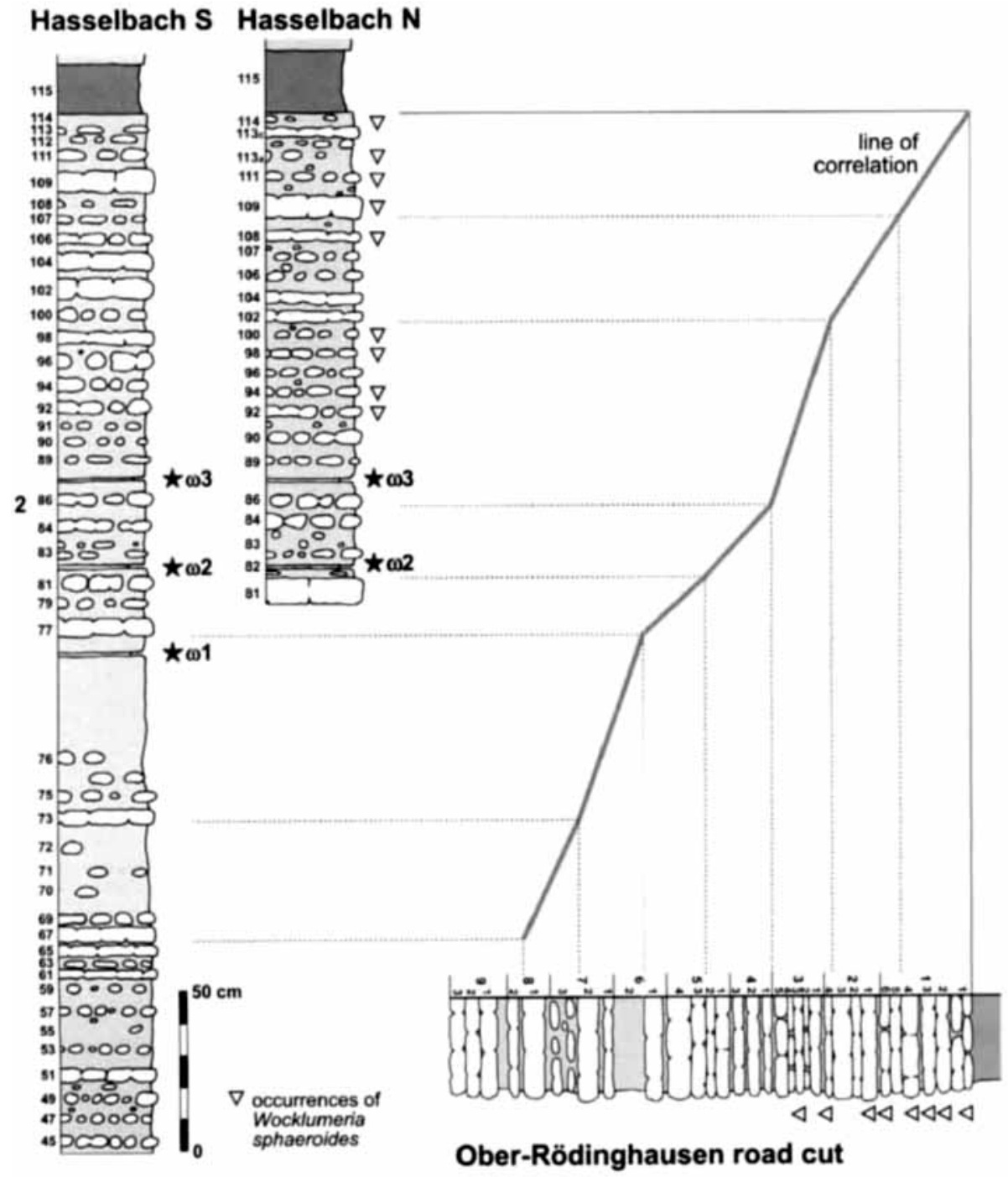

Fig. 10. Correlation of the Wocklum Limestone of the Hasselbach sections with the Ober-Rödinghausen road cut section on the basis of lithology and ammonoid distribution. Data from Ober-Rödinghausen after $\mathrm{H}$. J. Thiem (unpublished). 
the best conditions for a lithology-based subdivision of the Hangenberg Limestone. They show almost regularly distributed limestone/shale successions with both components in similar proportions and carbonate peaks that are well-defined. The Hasselbachtal section has the highest clay content; carbonate peaks are thus less striking. In contrast to this, the sections at Ober-Rödinghausen (railway cutting and road cutting) are predominantly made up of carbonate with minor shale intercalations. Carbonate curves of these sections are less informative, because several nodular limestone beds of other sections can be amalgamated into thicker units.

Within the Hangenberg Limestone, 13 major peaks in the carbonate concentration curves (c1-c13) can be recognised in the sections at Hasselbach, Apricke, and Oese. Between some of these maxima, second-order peaks can be seen. The magnitude of the major peaks differs between the two sections, but they can easily be correlated. This results in an almost linear correlation, as evident in the sections at Hasselbach and Apricke (Fig. 11). This correlation is supported by the presence of metabentonite layers (named here $\alpha 1$ to $\alpha 3$ ), which occur in the sections at Hasselbachtal, Oese, and Apricke. Correlation of the sections of Apricke and Oese with the railway cut section at Ober-Rödinghausen also works rather well. The main difficulty is

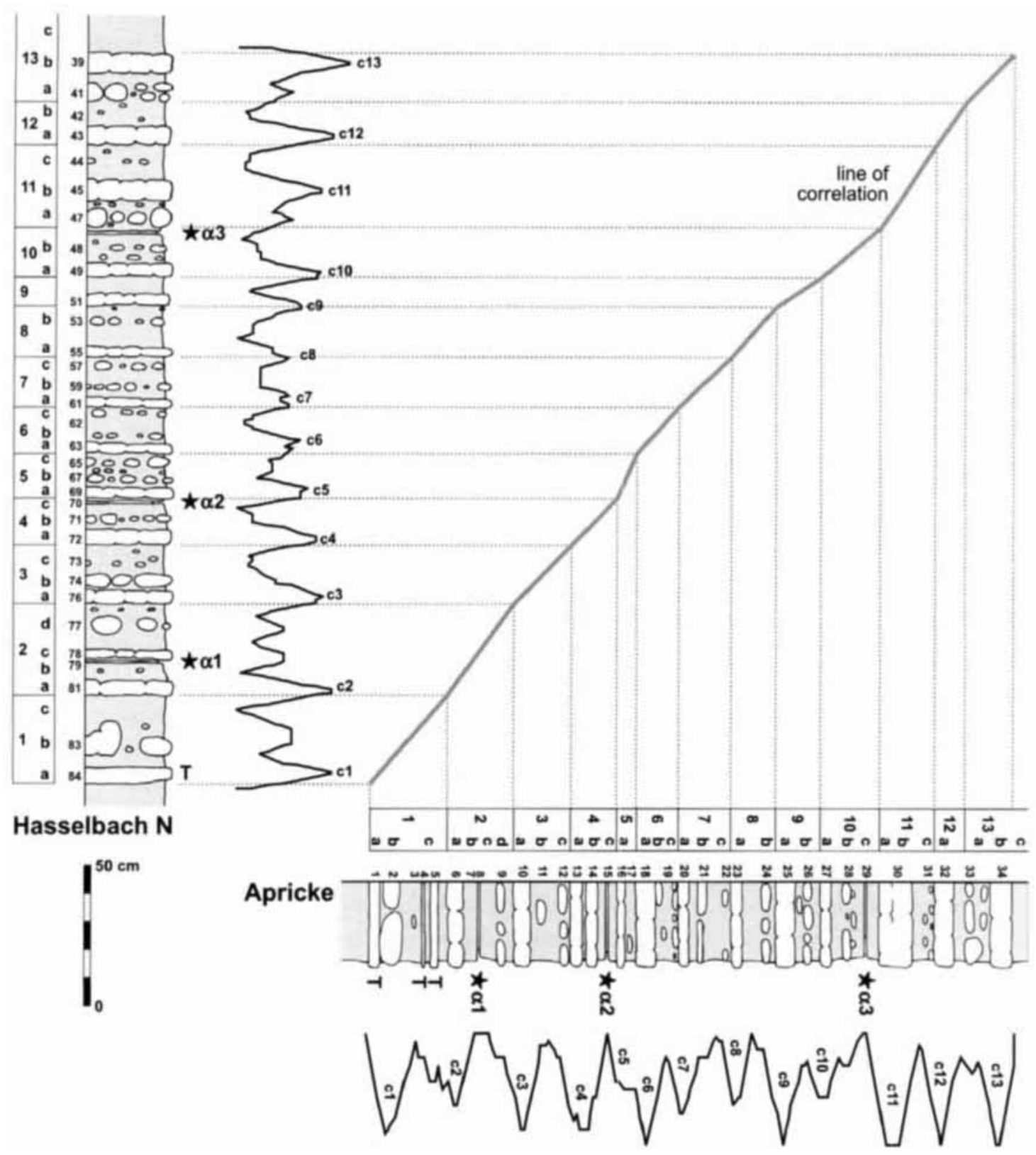

Fig. 11. Correlation of the Hangenberg Limestone of the Hasselbach $\mathrm{N}$ section with the Apricke section on the basis of lithology (especially carbonate curves). 
the much lower clay content in the sections at Ober-Rödinghausen, which led to an amalgamation of the limestone beds.

Based on the vertical carbonate distribution, the Hangenberg Limestone can be subdivided into 13 lithological units which contain a total of approximately 35 single limestone horizons. The 13 units are defined by a rhythmic succession of strata, usually a nodular limestone bed at the base and followed by isolated nodules in shales and then followed by pure shales. In most of the cases, the lower limit of the cycle is marked by the base of a solid limestone bed.

All 13 units are clearly visible in the Hasselbach and Apricke sections. The Oese section shows an amalgamation of units 12 and 13 which, in the Ober-Rödinghausen railway cut, are separated by a thin claystone vein. A new uniform terminology of the beds is proposed herein for the Hangenberg Limestone in the sections investigated, and consists, in ascending order, of beds 1 to 13 (Fig. 6).

The Hasselbach and Apricke sections display the clearest cyclicity in the sediments, with decreasing carbonate content in each cycle. Such a succession cannot be traced in the sections near Ober-Rödinghausen, where many of the units are represented by only one carbonate bed, reflecting the amalgamation of several horizons.

Comparison of the sections shows that the Hasselbach and Apricke sections, in particular, are very similar, and even a bed-by-bed correlation can be achieved. Both show a platy turbiditic limestone at the base, and both show three metabentonite horizons (here named $\alpha 1, \alpha 2$, and $\alpha 3)$ at the same positions. Even the distribution of nodular beds and more compact beds shows almost perfectly correspondence. The carbonate curves have an almost identical profile. The main difference between the two sections is the slightly higher clay content at Hasselbach. Other differences include the absence of bed $2 b$ at Apricke and the lack of thin turbiditic beds (1c) at Hasselbach.

The five sections show a continuous transition from a clay-dominated (Hasselbach) to a carbonate-dominated section (Ober-Rödinghausen), although this does not agree with the geographic position running from West to East. With decreasing clay content, the nodular limestone beds tend to amalgamate, as seen in the lower and upper parts of the sections near Ober-Rödinghausen.

The basal nodular limestone bed of the Hangenberg Limestone yielded ammonoids and con- odonts of the so-called "Stockum Fauna". Their Protognathodus Fauna does not at all contain any specimen of Siphonodella due to unknown facial reasons. The frequently used explanation by shallow (Protognathodus) and deep (Siphonodella) facies does not work; the true shallow water representatives of Siphonodella (Ji \& Ziegler 1992) never have been recorded in Germany. We collected Nicimitoceras cf. carinatum (Schmidt, 1924) in bed 83 of the Hasselbach $N$ section and bed 2 of the Apricke section, one of the index ammonoid species of the Acutimitoceras prorsum Zone. Although additional confirmation would be acknowledged, these records lead us to the conclusion that the classical Stockum ammonoid assemblage has to be placed in the earliest Carboniferous, as already proposed by Becker (1996: tab. 2). Two records of Siphonodella sulcata from bed 84 in the Hasselbach $\mathrm{N}$ section exist, (1) the specimen of Groos-Uffenorde \& Uffenorde (1974), which was in our hands and shown to Ludmilla Kononova (Moscow), who confirmed the determination without any doubts, and (2) one of the specimens figured by Kürschner et al. (1993: pl. 4: 1-2), which is obviously correctly identified, whereas the second specimen (pl. 4: 3-4) has to be assigned to Polygnathus.

Between the top limestone bed of the Hangenberg Limestone Member (of Hangenberg Formation) and the anoxic crenulata Event (base of lower Alum Shale Formation), there is a hitherto mostly neglected, but rather long time interval without ammonoid zonation, best represented by sediments thicker than the Hangenberg Limestone (or its equivalents) itself in two sections: $4.34 \mathrm{~m}$ ostracode shales in the Hasselbach 1/1987 borehole (depth 20.10-24.44 m; see Fig. 5, sequence 13c) of the Rhenish Mountains, and the upper $4.32 \mathrm{~m}$ of the Pfaffenberg Member of the Gleitsch Formation (beds 9 $\alpha-11$; Bartzsch \& Weyer 1982: fig. 9) in the Bohlen section of Thuringia. The existence of this still unnamed lithostratigraphic unit was first demonstrated by Groos-Uffenorde \& Uffenorde (1974: fig. 2). It belongs, at least for the greater part, to the longlasting Siphonodella sandbergi Zone and would occupy a later unit, indicated by Sandberg et al. (1978: 114) as a future possible "Upper sandbergi Subzone", defined by the first occurrence of Siphonodella lobata (Branson \& Mehl 1934), which was found near the base in the Bohlen section (Pfaffenberg NE) of Saalfeld (Bartzsch \& Weyer 1982: 25). On the other hand, Voges (1960: 208) recorded that species already in the 
upper Paragattendorfia patens Zone, and Ji (1985: fig. 1) observed in Chinese sections a first occurrence even below the first Siphonodella sandbergi Klapper, 1966. The thickness changes in other sections (Drewer: $0.45 \mathrm{~m}$; Weyer 1994: fig. 1, bed 17) up to extreme condensation (Ober-Rödinghausen railway cut: $0.05 \mathrm{~m}$; Fig. 5, bed $0=$ sequence $13 \mathrm{c}$ ) or even complete lack. Most probably, the highest part of these "ostracod shales" represent already the Siphonodella crenulata Zone (evidence from Schübelhammer section in Upper Franconia; Gandl 1968: 507, and our own collections). There was never a prove that the anoxic "crenulata Event" (base of Lower Alum Shale Formation in the Rhenish Mountains or base of Rußschiefer Formation in Thuringia) really coincides with the base of that biozone.

\section{Volcanic ashes and numerical ages}

The presence of six volcanoclastic horizons around the Devonian-Carboniferous Boundary in the Hasselbach section (Figs 3,5) is an interesting feature and was already used for one numerical age determination based on included zircon crystals.

The Lower Tournaisian metabentonite $\alpha 1$ (bed 79) was first mentioned by Becker et al. (1984: 185 , see also Winter 1993), the second horizon

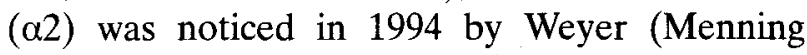
et al. 2001: 13), and the third one ( $\alpha 3$ ) was found in 2000 by the authors while searching for an equivalent of the $30 \mathrm{~cm}$ thick clay of the neighbouring Oese section (recorded by Paproth et al. 1986: 3, Clausen et al. 1987: 29). Two of these metabentonite layers: $\alpha 1$ (Stoppel in Luppold et al. 1994: fig. 5), $\alpha 2$ (pers. comm. by Dr. K. Hahne, Potsdam) are also known from the Hasselbach 1/1987 borehole. Clausen et al. (1987: 32) also reported several metabentonite layers in the Hasselbach section.

The Upper Famennian volcanic ashes $\omega 2$ and $\omega 3$ at Hasselbach $N$ were first excavated and mentioned by Weyer (1995: 106, fig. 1), and then Becker (1996: 22, fig. 2), although the existence (including w1) was already well known to Dr. E. Paproth and her team following an excavation (Korn in 1988) in the upper "Wocklumeria" Stufe $\mathrm{V}$ at Hasselbach S. The first publication of that measured sequence (Luppold et al. 1994: fig. 3) is generalised and lacks corresponding explanations of the clearly indicated thin layers that represent tuffs $\omega 2$ and $\omega 3$. Becker (1996: 23) noted the better quality of the original drawing distributed in 1988 among members of the International Working Group for the Devonian-Carboniferous Boundary; that document (shown in Fig. 3) also indicates metabentonite $\omega 1$ which is no longer accessible.

Following the advice of Winter (1993: 685) and Dr. E. Trapp (pers. comm.) regarding the probable larger regional extension of such airdistributed volcanic ashes, most of these horizons were recorded in the nearby sections of Apricke and Oese (Figs 4, 6; partially cited in Korn 2002: 7 , 8, figs 5-6) during our fieldwork of 2000 . A note by R. T. Becker et al. (1993: 35), that the thick $30 \mathrm{~cm}$ layer at Oese is probably not a tuff, is no longer valid; geochemical data kindly provided by Dr. K. Hahne (Potsdam) clearly prove its volcanic ash nature.

Metabentonite $\alpha 1$ (bed 79, lower part of Gattendorfia subinvoluta Zone of Vöhringer $1960=$ Acutimitoceras acutum Zone; middle of Siphonodella sulcata Zone) was dated by Claoué-Long et al. (1992, 1993, SHRIMP method) as $353.2 \pm 4.0 \mathrm{Ma}$, and later (1995) calibrated to $353.7 \pm 4.2 \mathrm{Ma}$. It forms the basis for long quoted value of $354 \mathrm{Ma}$ for the DevonianCarboniferous Boundary (Menning et al. 2001: 13). Parallel zircon analyses by Kramm et al. (1991, cited also in R. T. Becker et al. 1993: 33) indicated a different result of $346,6 \pm 1,6 \mathrm{Ma}$, commented on by Claoué-Long et al. (1993: 546). A much older date of $362 \mathrm{Ma}$ for the Devonian-Carboniferous Boundary was postulated by Tucker et al. (1998). Such controversial data (with a difference of $8 \mathrm{Ma}$ ) led to compromise dates, for example, $358 \mathrm{Ma}$ (Menning et al. 2002). Compston (2000: 1140,1144$)$ re-estimated the age of this ash layer $(\alpha 1)$ as being 359.6 Ma.

\section{The relative length of the stratigraphic units near the Devonian-Carboniferous Boundary}

With regard to the duration of certain biozones in Early Tournaisian times, the studied sections at Hasselbach to the Ober-Rödinghausen railway cutting may contribute information concerning their relative lengths when estimated against thicknesses in the sequences of the Hangenberg Limestone ("Gattendorfia Stufe").

An estimate of the relative and absolute lengths of the various stratigraphic units can be achieved using the sedimentary record of the studied sections. It should be kept in mind, how- 
ever, that there are very little numerical data for Devonian and Carboniferous ages, and that most of the subdivisions are largely speculative.

The following attempt to calculate the lengths of the units begins with some basic assumptions and additional estimations:

- The total length of the Famennian has an estimated length of $15.5 \mathrm{Ma}$ (Menning et al. 2002). This length is not supported by empirical data and is only a rough estimation.

- The lengths of the stratigraphic interval between the annulata Black Shale (Platyclymenia annulata Zone) and the Hangenberg Black Shale can be estimated at $7 \mathrm{Ma}$. This is based on an evaluation of sediment accumulation.

- In the Saalfeld sections, $22 \mathrm{~m}$ of shales and nodular limestones represent this time unit (Bartzsch et al. 1998). This means, in the case of regular sediment accumulation, a thickness of one metre of sedimentary rocks accumulated in approximately 300000 years.

- In the Saalfeld sections, four metres of Gattendorfia Limestones (shales with intercalated limestone beds and nodules in the same facies as the Upper Famennian strata; see Fig. 19) are present. If the calculation of the length of the Devonian units is applied to these, a duration of approximately $1.2 \mathrm{Ma}$ can be expected for this interval.

- Biostratigraphic data, especially for ammonoids and conodonts, provide evidence for a simultaneous deposition of the Gattendorfia

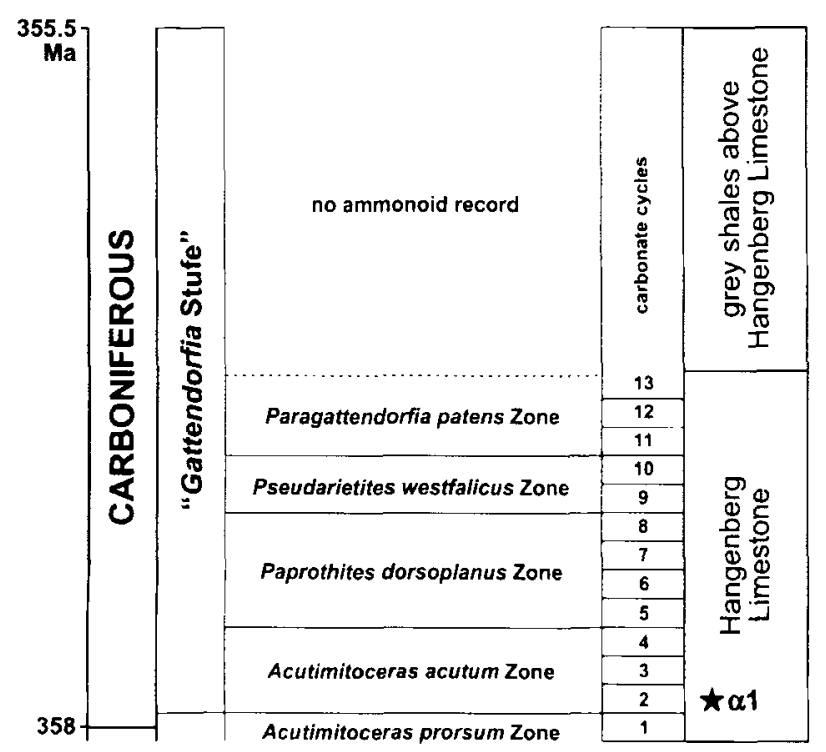

Fig. 12. Calculated lengths of the ammonoid zones within the Hangenberg Limestone and the overlying grey shales. Metabentonite horizon $\alpha 1$ indicated by an asterisk.
Limestone in the Thuringian and Rhenish Mountains.

- Within the $1.2 \mathrm{Ma}$ of duration, 13 cycles of carbonate sedimentation can be counted, consequently each cycle represents approximately 100000 years.

The relative lengths of the ammonoid zones within the basal Tournaisian differ, but their estimated lengths can be determined from Fig. 12.

\section{Conclusions}

Detailed investigation of the Devonian-Carboniferous Boundary sections on the northern flank of the Remscheid-Altena Anticline (Rhenish Mountains) led to the following results:

1. Several lithological and palaeontological features can be used to correlate the sections, for instance: (1) fluctuations in the carbonate and clay contents, (2) volcanoclastic layers, and (3) conodont and ammonoid occurrences.

2. Correlation of these features led to an extremely fine subdivision of the sections; units much shorter than ammonoid- and conodont zones can be discriminated.

3. A composite standard for the northern Remscheid-Altena Anticline is proposed, enabling correlation with more distant sections.

4. The total length of the "Gattendorfia Stufe", represented by rock units of the Hangenberg Limestone and overlying grey shales up to the base of the lower Alum Shale, is calculated as approximately $2.5 \mathrm{Ma}$.

5. The length of each carbonate cycle within the Hangenberg Limestone is estimated at 100000 years.

6. The Acutimitoceras prorsum ammonoid Zone belongs, at least in its higher part, in the Siphonodella sulcata conodont Zone, i.e., in the Carboniferous.

7. The facially induced absence of Siphonodella sulcata in Protognathodus-dominated conodont faunas does not automatically mean that these belong in the late Siphonodella praesulcata Zone.

8. Between the Hangenberg Limestone and the lower Alum Shale, a shale unit of maximally 5 metres thickness represents a yet undefined biostratigraphic interval. 


\section{Palaeontological descriptions}

\section{Ammonoids}

[Abbreviations used in the text are $\mathrm{dm}$ - conch diameter, ww - whorl width, wh - whorl height, uw - umbilical width, ah - apertural height, WER - whorl expansion rate, calculated [dm/ $(\mathrm{dm}-\mathrm{ah})]^{2}, \mathrm{IZR}$ - imprint zone rate, calculated (wh-ah)/wh (Fig. 13). The described and illustrated specimens are housed in the collection of the Museum für Naturkunde der Humboldt-Universität zu Berlin, with the catalogue numbers MB.C.5231 to MB.C.5300.]

Family Prionoceratidae Hyatt, 1884

Subfamily Prionoceratinae Hyatt, 1884

\section{Paragattendorfia Schindewolf, 1924}

Type species: Paragattendorfia humilis Schindewolf. 1924

\section{Paragattendorfia n. sp. I}

Pl. 2: 20-21

Material: Five specimens from Oese (beds 22 and 28), $5-16$ millimetres in diameter, preserved with shell ornament.
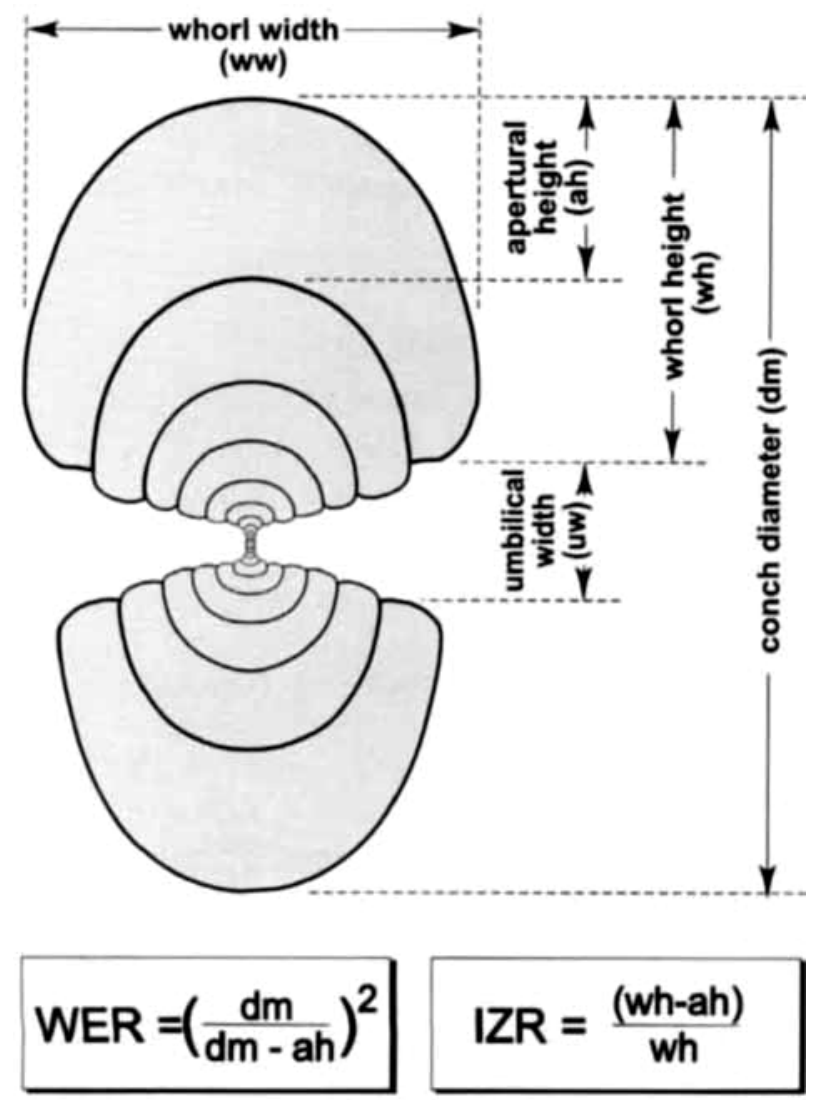

Fig. 13. The conch parameters and ratios as used in the ammonoid descriptions.
Description: The smaller specimen MB.C.5260.3 (Pl. 2, Figs 20-21) has an almost ball-shaped conch with a small umbilicus and a low aperture. The ornament of this specimen consists of fine growth lines which are strongly rursiradiate in their course. They form a dorsolateral projection and turn back to run with a wide sinus across flanks and venter. The larger specimen MB.C.5262.2 displays a similar growth line course, but with less strong backward turn of the growth lines.

Since there are only juvenile specimens available so far, the species is left in open nomenclature. The difference to Globimitoceras globiforme (Vöhringer, 1960) is the wider umbilicus (0.16 in Paragattendorfia n. sp., 0.08 in Globimitoceras globiforme).

\section{Subfamily Acutimitoceratinae Korn 1994}

\section{Hasselbachia n. gen.}

Type species: Imitoceras multisulcatum Vöhringer, 1960.

Genus definition: Genus of the subfamily Acutimitoceratinae with low aperture (WER 1.50). Closure of the umbilicus in the adult stage by a significant overlap of the flanks. Suture line with equally deep external and adventive lobes.

Included species:

gracile: Imitoceras gracile Vöhringer, 1960. Hangenberg Limestone, Rhenish Mountains.

multisulcatum: Imitoceras multisulcatum Vöhringer, 1960. Hangenberg Limestone, Rhenish Mountains.

sphaeroidale: Imitoceras sphaeroidale Vöhringer, 1960. Hangenberg Limestone, Rhenish Mountains.

Discussion: The three known species which belong to the new genus share several characters, which allow a clear separation from Mimimitoceras, Acutimitoceras and Paragattendorfia. They have a low aperture and hence slowly expanding whorls (WER 1.50); this contrasts species of Acutimitoceras, in which this value ranges from 1.80 and 2.05. Species of Paragattendorfia have similarly low apertures (WER 1.45). In Hasselbachia, the umbilicus opens continuously during the inner whorls, with a uw/dm ratio that only slightly decreases from 0.45 at $3 \mathrm{~mm}$ to 0.35 at $12 \mathrm{~mm}$ conch diameter. At approximately $16 \mathrm{~mm}$, the umbilicus still has 0.2 of the conch diameter. In this respect, the new genus is intermediate between Paragattendorfia (in which the umbilicus has a rather constant width and does not become closed in the adult whorls) and $\mathrm{Acu}$ timitoceras (in which the relative width of the umbilicus increases during early ontogeny, and closure of the umbilicus starts already in an immature stage). In Hasselbachia, the umbilicus is 
closed in the adult stage by a significant overlap of the flanks over the umbilicus. Hasselbachia is remarkable because it combines characters which are present in other genera: the low WER as in Mimimitoceras, the continuous opening of the umbilicus in the inner whorls as in Paragattendorfia, and closure of the umbilicus is more similar to Acutimitoceras.

\section{Hasselbachia multisulcata (Vöhringer, 1960)}

Fig. 14E, F, Pl. 1: 7-8

1960 Imitoceras multisulcatum - Vöhringer: 141, pl. 4: fig. 5.

1976 Imitoceras multisulcatum - Weyer: 841, fig. 4.

1981 Imitoceras (Imitoceras) multisulcatum - Ruan: 80 . pl. 18: figs 5-7, pl. 19: figs 1-13.

1994 Acutimitoceras multisulcatum - Korn: 47, textfigs 49G, L, 50J, K, 51C, 55B.

1996 Acutimitoceras (Stockumites) multisulcatum - Becker: 36.

Material: Four specimens, ranging in their sizes from 10 to $15 \mathrm{~mm}$, from bed 57 of the Hasselbach section.

Description: The cross section MB.C.5240.3 shows whorls from 1.6 to $14 \mathrm{~mm}$ conch diameter; the earliest stage is missing. Already at $1.6 \mathrm{~mm}$ $\mathrm{dm}$, the whorl cross section is ventrally strongly depressed, and is more than twice as wide as high. A similar shape of the section is still displayed at $11.4 \mathrm{~mm}$ conch diameter. During this period of growth, the umbilicus opens continuously to a maximum of 4 millimetres, with the ww/dm ratio being reduced from 0.45 to 0.35 . During the penultimate half-volution, the cross section has markedly changed: The inner flank overlaps the preceding whorl and leads to a spontaneous narrowing of the umbilicus (uw/dm 0.25 ). The same shape can be seen in the last, incompletely preserved half-volution. In the cross section, the WER decreases from 1.65 $(1.6 \mathrm{~mm} \mathrm{dm})$ to $1.45(14 \mathrm{~mm} \mathrm{dm})$; at the same time, the IZR increases from 0.40 to 0.60 . This means that the whorl cross-section has a conspicuous horseshoe-shaped outline.

The second cross section (specimen MB.C.5240.2) is of a larger specimen which principally resembles specimen MB.C.5240.3. The in- ner whorls show the same development of the conch geometry, and the adult stage demonstrates the rather sudden closure of the umbilicus by whorls which strongly overlap of the inner flank. The last completely preserved halfvolution displays a slight flattening of the strongly converging flanks.

The ornament can best be studied in specimen MB.C.5240.1. The growth lines are rather coarse and run almost linear across flanks and venter. In the midflank, shallow constrictions can be seen. Their number is approximately ten on a volution, but at the end of the preserved portion, they are more densely arranged.

\section{Hasselbachia gracilis (Vöhringer, 1960)}

Pl. 1: 9-10, 15-16

1960 Imitoceras gracile Vöhringer: 143, pl. 4: fig. 6.

1994 Acutimitoceras gracile - Korn: 47, textfigs 49F, 55A.

1996 Acutimitoceras (Stockumites) gracile - R. T. Becker: 36.

Material: Three fragmentary specimens of 16 millimetres in diameter are available from beds 53 and 57 of the Hasselbach section.

Description: Both figured specimens display the ornament which is made of coarse, almost lamellose growth lines. In specimen MB.C.5240.5, they are biconvex with a relatively high dorsolateral projection, a shallow lateral sinus, and a low ventrolateral salient. They run straight over the venter. The flanks of both specimens show short and shallow constrictions in small distances.

\section{Acutimitoceras Librovitch, 1957}

Type species: Imitoceras acutum Schindewolf, 1923

\section{Acutimitoceras aff. intermedium (Schindewolf, 1923)}

Fig. 14C

Material: One specimen from the Hasselbach scction (bed 80) (MB.C.5249.3).

Plate 1. Ammonoids from the Hangenberg Limestone of the Hasselbach section, all coll. Weyer 1994 (21-24, coll. F. Trostheide 1994). 1-2. Acutimitoceras cf intermedium (Schindewolf, 1923), MB.C.5235.1. bed 46, ventral and lateral views, $\times 1$. 3-4. Nicimitoceras cf trochiforme (Vöhringer, 1960), MB.C.5234.1, bed 45, dorsal and lateral views, $\times 2.5$. 5-6. Pseudarietites westfalicus Schmidt, 1924, MB.C.5236.1, bed 49, lateral and ventral views, $\times 3$. 7-8. Hasselbachia multisulcata (Vöhringer, 1960), MB.C.5240.1. bed 57, lateral and ventral views, $\times 2.5$. 9-10. Hasselbachia gracilis (Vöhringer. 1960), MB.C.5238.1, bed 53, lateral and ventral views. $\times 2.5$. 11-12. Globimitoceras globiforme (Vöhringer, 1960), MB.C.5240.7, bed 57, lateral and dorsal views, $\times 3$. 13-14. Gattendorfia molaris Vöhringer, 1960, MB.C.5240.8, bed 57, lateral and ventral views, $\times 2.5$. 15-16. Hasselbachia gracilis (Vöhringer, 1960), MB.C.5240.5, bed 57, lateral and ventral views. $\times 2.5$. 17-18. Paprothites sp., MB.C.5240.10, bed 57, lateral and ventral views, $\times 2.5$. 19-20. Paprothites sp., MB.C.5240.9, bed 57, lateral and ventral views, $\times 1.5$. 21-24. Paprothires ruzhencevi n. sp.. Holotype MB.C.5240.6. bed 57, lateral dorsal, and ventral views, $\times 2.5$. 

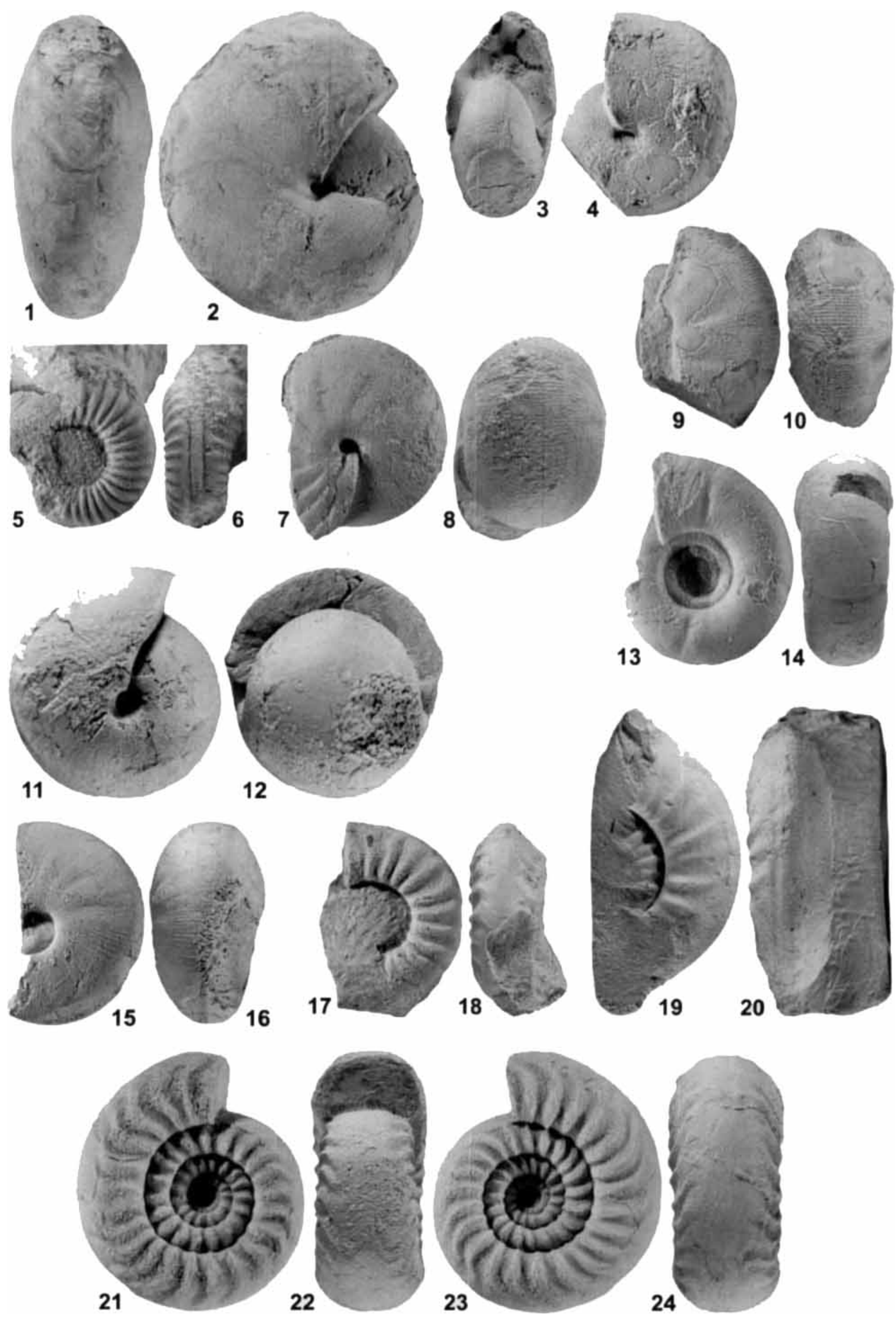

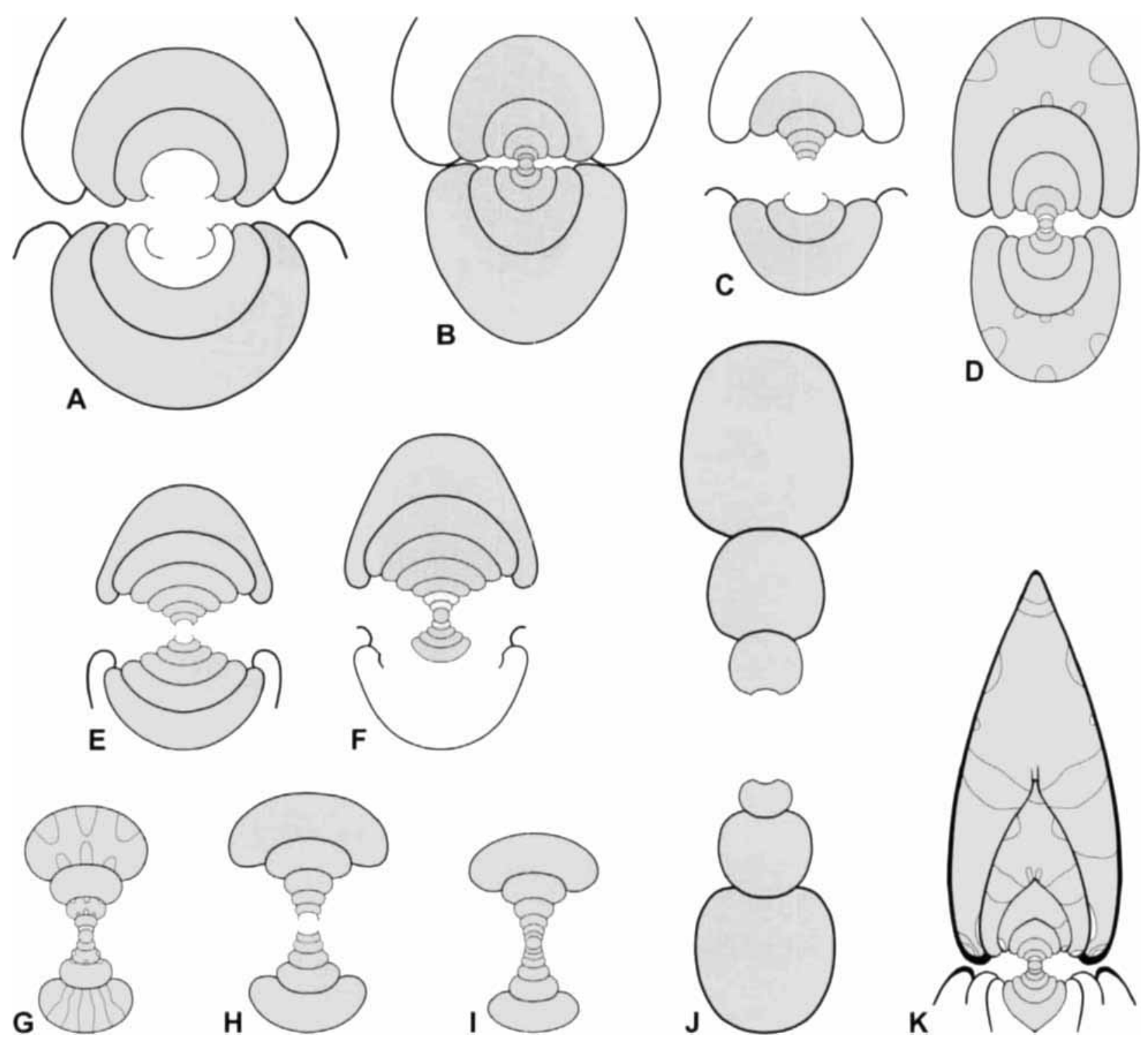

Fig. 14. Cross sections of ammonoids from the Hangenberg Limestone of the Hasselbach section (coll. Weyer 1994) and of the Oese section (coll. Korn and Weyer 2000; coll. E. Paproth), all $\times 2.5$. A. Mimimitoceras varicosum (Schindewolf, 1923), MB.C.5263, Oese, bed 11. B. Acutimitoceras cf simile (Vöhringer, 1960), MB.C.5249.4, Hasselbach, bed 80. C. Acutimitoceras aff. intermedium (Schindewolf, 1923), MB.C.5249.3. Hasselbach, bed 80. D. Acutimitoceras subbilobatum (Münster, 1839), MB.C.5292, Oese, lower part of Hangenberg Limestone. E. Hasselbachia multisulcata (Vöhringer, 1960), MB.C.5240.3, Hasse1bach, bed 57. F. Hasselbachia multisulcata (Vöhringer, 1960), MB.C.5240.2, Hasselbach, bed 57. G. Gattendorfia subinvoluta (Münster, 1832), MB.C.5247.1, Hasselbach, bed 76. H. Gattendorfia costata Vöhringer, 1960, MB.C.5249.1, Hasselbach, bed 80. I. Gattendorfia costata Vöhringer, 1960, MB.C.5249.2. Hasselbach, bed 80. J. Eocanites sp., MB.C.5234.2, Hasselbach, bed 45. K. Voehringerites peracutus (Vöhringer, 1960), MB.C.5245.1. Hasselbach, bed 72.

Description: Cross section MB.C.5249.3 is incomplete in the inner whorls, but clearly shows the transformation from the evolute juvenile to the narrow-umbilicate adult stage. Up to $5 \mathrm{~mm}$ diameter, the conch is serpenticonic with crescent-shaped whorl cross-sections. The next halfwhorl shows already a more pronounced lateral growth, and at $12 \mathrm{~mm}$ diameter, the conch is thickly discoidal to pachyconic. In this stage, the umbilicus is widest with $2.7 \mathrm{~mm}$. In later stages, the umbilicus starts to close, and the whorl width becomes more prominent.

\section{Acutimitoceras cf simile (Vöhringer, 1960)}

Fig. 14B

cf. 1960 Imitoceras liratum simile - Vöhringer: 127, pl. 2, fig. 4. cf. 1981 Imitoceras (Imitoceras) simile - Ruan: 75, pl. 16: figs $10-12$.

cf. 1994 Acutimitoceras simile - Korn: 49, textfigs 46A, B, $47 \mathrm{D}, 50 \mathrm{G}, 54 \mathrm{~A}$.

Material: One specimen from bed 80 of the Hasselbach section (MB.C.5249.4).

Description: In the cross section of specimen MB.C.5249.4 (Fig. 14B), the transformation of the conch geometry from the earliest juvenile to 
the pre-adult stage can be studied. In the first two whorls, the umbilicus is moderately wide (uw/dm 0.22). During the $2^{\text {nd }}$ and $4^{\text {th }}$ whorl (up to $8 \mathrm{~mm}$ conch diameter), the umbilical width remains stable at approximately $0.5 \mathrm{~mm}$, with the uw/dm ratio decreasing from 0.22 to 0.06 . The complete closure of the umbilicus takes place within the $5^{\text {th }}$ whorl. Ontogenetic transformations can also be observed in the shape of the whorl cross sections. The first two whorls show a crescent-shaped section, and the $3^{\text {rd }}$ and $4^{\text {th }}$ are semi-circular. In the $5^{\text {th }}$ whorl, the section is already laterally compressed. During ontogeny, the whorl expansion rate (WER) increases from 1.75 to 2.00 , and the imprint zone rate (IZR) amounts 0.50 in stages larger than $5 \mathrm{~mm}$.

Subfamily Voehringeritinae Bartzsch \& Weyer, 1988

\section{Voehringerites Manger, 1971}

Type species: Karagandoceras peracutum Vöhringer, 1960.

\section{Voehringerites peracutus (Vöhringer, 1960)}

Figs $14 \mathrm{~K}, 15 \mathrm{~A}-\mathrm{C}$

1960 Karagandoceras peracutum - Vöhringer: 166, fig. 43 , pl. 1: fig. 3 .

1971 Voehringerites peracutum - Manger: 36, fig. 3A, 4, pl. 12: figs 4,7 .

non 1981 Voehringerites peracutus - Korn: 524, fig. 5.

1988 Voehringerites peracutus - Bartzsch \& Weyer: 40.

1994 Voehringerites peracutus - Korn: 65, figs 31F-G, $63 \mathrm{~A}, 71 \mathrm{~B}$.

non 1996 Voehringerites cf peracutus - Bartzsch \& Weyer: 77 , figs $1-5$.

Material: One specimen of approximately $35 \mathrm{~mm}$ diameter from bed 72 of the Hasselbach section (MB.C.5245.1).

Description: Cross section MB.C.5245.1 was produced from a fully septate specimen of approximately $40 \mathrm{~mm}$ diameter. Unfortunately, three half-whorls on one side are only fragmentary preserved. Nevertheless, the specimen excellently displays the ontogenetic development of the conch from the early juvenile up to the adult stage. The first $3 \frac{1}{2}$ whorls are rather widely umbilicate (uw/dm 0.30 ) with a rounded venter. In the next $1 \frac{1}{2}$ whorls, the venter forms a keel, and the terminal $2 \frac{1 / 2}{2}$ whorls are oxyconic.

At a diameter of approximately $18 \mathrm{~mm}$ (ww $5.7 \mathrm{~mm}$, wh $9.1 \mathrm{~mm}$ ), the cross section displays a feature which is not known from any other $\mathrm{Pa}$ laeozoic ammonoid. It is the combination of an oxyconic venter with a sharp double keel. Such skid-like keels are known from a number of ammonoids, but in all known other examples they
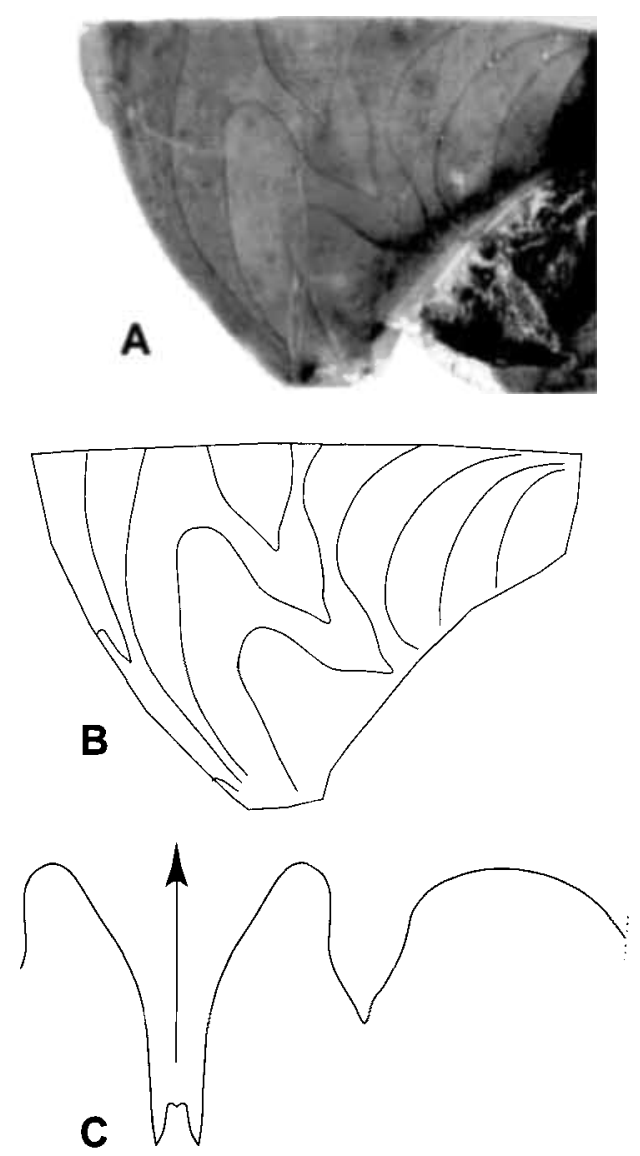

Fig. 15. Suture line of Voehringerites peracutus (Vöhringer, 1960), MB.C.5245.1, Hasselbach, bed 72, all $\times 2.5$. A, lateral view of the specimen. $\mathbf{B}$, successive sutures of the specimen. C, external suture line.

delimit a tabulate venter (e.g., Gyroceratites, see Walliser 1962; Armatites, see Termier \& Termier 1948) or are formed on a rounded or slightly flattened venter (e.g., Kosmoclymenia, see Korn 1979) where they were developed into nested "parabolic ears" on the venter.

The mature suture line of the specimen is remarkable for its extremely deep external lobe, which extends to be almost twice as deep as the adventive lobe (Fig. 15C). It has a Y-shaped outline with a very narrow lower half, in which a low median saddle is visible. The ventrolateral saddle is rounded and continues in the slightly asymmetric, lanceolate adventive lobe.

Discussion: This new record and additional material from the type locality (Weyer collection, beds $5 \mathrm{a} 2,5 \mathrm{~b}$ ) prove a more precise age: basal early Siphonodella duplicata Zone (= bransoni + duplicata Zones of Ji 1985), not Siphonodella sulcata Zone. Specimens attributed to Voehringerites peracutus by Korn (1981) and Bartzsch \& Weyer (1996) have a much shorter external lobe (perhaps without median saddle) and are more closely related to the still poorly known taxon 
gen. nov. I aff. Karagandoceras Librovich, 1940, which was also found in the La Serre stratotype section of Montagne Noire (one fairly well preserved specimen, Weyer collection).

Family Gattendorfiidae Bartzsch \& Weyer, 1987 Subfamily Gattendorfiinae Bartzsch \& Weyer, 1987

\section{Gattendorfia Schindewolf, 1920}

Type species: Goniatites subinvolutus Münster. 1839.

\section{Gattendorfia costata Vöhringer, 1960}

Fig. 14H, I

1952 Gattendorfia crassa - Schindewolf: 296, pl. 2: fig. 5.

1960 Gattendorfia costata - Vöhringer: 152, pl. 5: fig. 7

1977 Gattendorfia costata - Weyer: 173, pl. 1: figs 1,7

1982 Gattendorfia costata - Bartzsch \& Weyer: 19, textfig. 4/2

1994 Gattendorfia costata - Korn: 73, textfigs 65C. 66D, 67A.

Material: Three specimens from beds 76 and 80 of the Hasselbach section (MB.C.5249.1-3).

Description: Two sections (MB.C.5249.1, MB.C.5249.2; Fig. 14H, I) can be studied, and both are very similar in their character unfolding. Up to $8 \mathrm{~mm}$ diameter, the serpenticonic conchs have a wide umbilicus (uw/dm 0.55). The later whorls show already a reduction of the umbilical width index. The whorl width index (ww/wh) is in all stages of the two specimens (up to $12 \mathrm{~mm}$ $\mathrm{dm}$ ) around 2.00.

Discussion: It is noteworthy that $G$. costata is the stratigraphically oldest representative of the genus, occurring earlier than G. subinvoluta, as already known from Saalfeld (Bartzsch \& Weyer 1982).
Subfamily Pseudarietitinae Bartzsch \& Weyer, 1987

\section{Paprothites Bartzsch \& Weyer, 1987}

Type species: Pseudarietites westfalicus dorsoplanus Schmidt, 1924

\section{Paprothites ruzhencevi n. sp.}

Pl. 1: $21-24$

Holotype: Specimen MB.C.5240.6 (coll. F. Trostheide).

Derivation of name: After the late V.E. Ruzhencev $(1899-1978)$, in honour of his magnificent contribution to the knowledge of Palaeozoic ammonoids.

Type locality and horizon: Hasselbach rivulet (Rhenish Mountains); Gattendorfia Limestone; bed 57.

Material: Only the holotype MB.C.5240.6, a well-preserved specimen of $20 \mathrm{~mm}$ conch diameter is available for study.

Diagnosis: Species of Paprothites with wide umbilicus (uw/dm 0.50 ) and broadly rounded venter. Ornament with sharp ribs which run with a concave arc across the flanks and project to a high ventrolateral salient.

Description: The conch of the single specimen is thickly discoidal, with a depressed crescent-shaped whorl section (ww/wh 1.60-1.75), and a wide umbilicus (uw/dm 0.50). Umbilical wall, flanks, and venter are rounded and not bordered from each other. Of these conch parameters, the umbilical width obviously does not significantly change during ontogeny. The relative whorl width changes in the course of ontogeny. Only during the last half whorl of the specimen, the ww/dm ratio decreases from 0.54 to 0.45 (and the ww/wh ratio from 1.75 to 1.60 ).

On the last volution, 23 sharp ribs can be counted, the penultimate whorl has 20 , and the third-last whorl 14 of them, visible in the umbilicus. These ribs are restricted to the flanks, they wedge out in the transition zone to the venter.

Plate 2. Ammonoids from the Hangenberg Limestone of the Hasselbach section, all coll. Weyer 1994 (1-13) and of the Oese section, all coll. Weyer \& Korn 2000 (14-27). 1-2. Acutimitoceras convexum (Vöhringer, 1960), MB.C.5241.1, bed 59, lateral and dorsal views, $\times 2$. 3-4. Mimimitoceras hoennense Korn, 1994. MB.C.5241.2, bed 59, dorsal and lateral views, $\times 2.5$. 5. Gattendorfia reticulum (Vöhringer, 1960), MB.C.5242.1, bed $62 \mathrm{~A}$, lateral view, $\times 2$. 6-7. Acutimitoceras subbilobatum (Münster, 1839), MB.C.5247.2, bed 76, lateral and ventral views, $\times 2$. 8-9. Acutimitoceras cf antecedens (Vöhringer, 1960), MB.C.5248.2, bed 77, ventral and lateral views. $\times 3$. 10-11. Gattendorfia subinvoluta (Münster, 1832), MB.C.5244.1, bed 71, dorsal and lateral views, $\times 3$. 12-13. Acutimitoceras intermedium (Schindewolf, 1923), MB.C.5248.1, bed 77, dorsal and lateral views, $\times 1.5$. 14-15. Gattendorfia evoluta Vöhringer, 1960, MB.C.5258.1, bed 30, dorsal and lateral views, $\times 6$. 16-17. Gattendorfia concava Vöhringer, 1960, MB.C.5260.1. bed 28, dorsal and lateral views, $\times 2.18-19$. Gattendorfia molaris Vöhringer, 1960, MB.C.5260.2, bed 28. dorsal and lateral views, $\times 2.5$. 20-21. Paragattendorfia n. sp. I, MB.C.5260.3, bed 28, dorsal and lateral views, $\times 4$. 22-23. Paprothites dorsoplanus (Schmidt, 1924), MB.C.5262.1, bed 22, dorsal and lateral views, $\times 3$. 24-25. Paragattendorfia n. sp. II, MB.C.5262.8, bed 22, ventral and lateral views, $\times 5$. 26-27. Acutimitoceras sp., MB.C.5262.9, bed 22, ventral and lateral views, $\times 4$. 

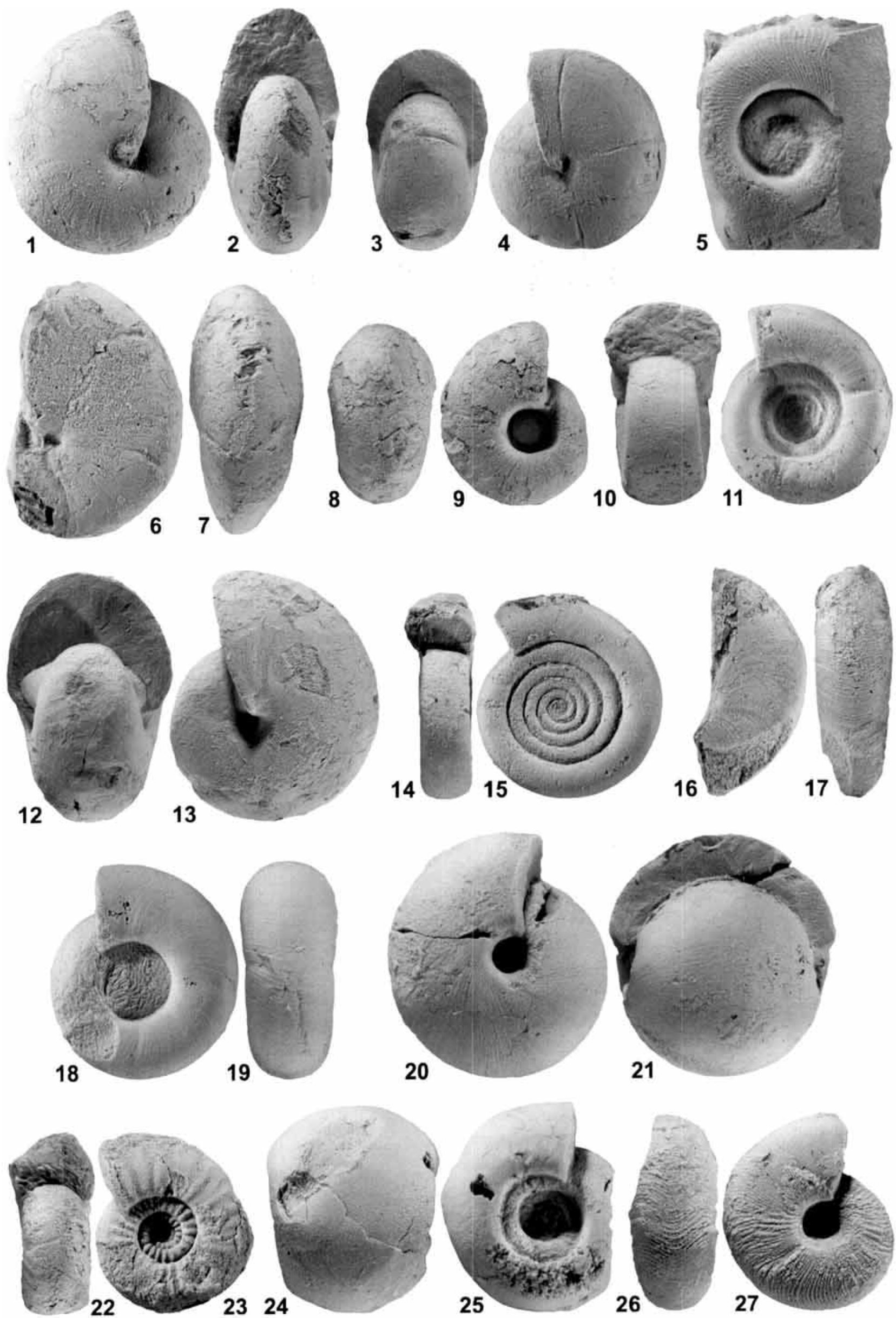
They run with a concave arc over the flank and project strongly forward. Fine growth lines run parallel the ribs; they form a prominent ventrolateral projection and turn back for a moderately deep ventral sinus.

Comparisons: Paprothites ruzhencevi differs from Pa. dorsoplanus (Schmidt, 1924) and Pa. raricostatus (Vöhringer, 1960) in the shape and course of the ribs, which in the latter two species are rounded and run almost straight over the flanks. Both species have thinner conchs and a much narrower umbilicus ( $\mathrm{uw} / \mathrm{dm}=0.35$ ) than the new species $(\mathrm{uw} / \mathrm{dm}=0.50)$.

The sharp and sinuous ribs of Pa. ruzhencevi are also a criterion to distinguish it from other, Chinese representatives of the genus, e.g. Pa. platyventrus (Ruan, 1981) and Pa.subquadratus (Ruan, 1981). These possess a slightly narrower umbilicus (uw/dm 0.45). Furthermore, Pa. platyventrus has 40 to 50 ribs per volution, much more than Pa.ruzhencevi. Pa.ellipticus (Ruan, 1981) is the most similar species; both in conch shape and ornament. The Chinese species has an even wider umbilicus (uw/dm 0.55) and a wider, more crescent-shaped whorl cross section (ww/wh over 2.00).

Pa. daposhangensis (Sheng, 1989) has much finer ribs and is thus easily distinguishable from the new species. It is even not clear if this species in fact belongs to Paprothites or to Gattendorfia.

\section{Paprothites sp.}

Pl. 1: $17-20$

Material: Six fragmentary specimens are available for study, ranging from 8 to $22 \mathrm{~mm}$ in diameter, all from bed 57 of the Hasselbachtal section.

Description: The small specimen MB.C.5240.10 bears 12 slightly arched ribs on the flanks. They suddenly disappear in the ventrolateral area, and the venter is smooth. The larger specimen (MB.C.5240.9) displays parts of two whorls, and the penultimate whorl displays the ribs as in the smaller specimen (MB.C.5240.10). The last whorl has weaker and shorter ribs, which are restricted to the inner flank. In this specimen, a barely visible ventrolateral groove is visible, and the venter has an indistinct keel, already clearly transitional to Pseudarietites.

\section{Rugose corals}

All drawings and photographs of cross sections are uniformly orientated, viewed from above or calice, cardinal septum upside, six protosepta marked by arrows or dots. The following abbreviations are used: CS - cross section, LS - longitudinal section, $\mathrm{P}$ - acetate peel, TS - thin section, $\mathrm{R}$ - remaining piece (of corallum), $\mathrm{D}-$ diameter, $\mathrm{n}$ - number of major septa, $\mathrm{N}$ - number of all septa.

Suborder Cyathaxoniina Spasskiy, 1977

Family Cyathaxoniidae Milne-Edwards \& Haime, 1850

Subfamily Cyathaxoniinae Milne-Edwards \& Haime, 1850

\section{Cyathaxonia Michelin, 1847}

\section{Cyathaxonia sp. B}

Fig. 16A-L, Pl. 4: 2-4

1972b "Syringaxon" nov. sp. - Weyer: pl. 1, fig. 1a-f (misidentification).

1984a Cyathaxonia (Cyathaxonia) sp. - Weyer: 21, photo 4/3.

Material: Two specimens from Hasselbach $\mathrm{N}$ (beds 81 and 65), Early Tournaisian ("Gattendorfia Stufe"), Acutimitoceras acutum Zone and Paprothites dorsoplanus Zone (coll. Weyer 1994): MB.K.673; 12CS (10P. 2TS) + 1R - Fig. 16A-G. Pl. 4: 3-4 and MB.K.674; 8CS (5P, 3TS) +1R - Figs 16H-L, Pl. 4: 2.

Description: The slender conical and slightly cornute corals (L 8 $+5.3 \mathrm{~mm}$, upper D $4+1.8 \mathrm{~mm}$, lower $\mathrm{D} 1+0.6 \mathrm{~mm}$ ) represent the common species of Cyathaxonia of the "Gattendorfia Stufe" (represented by cypridinic shales and cephalopod limestones) in Germany, here illustrated by the serial cross sections of a juvenile and of an adult individual. The archaeothecal wall bears strong or weak septal furrows; the cardinal septum is situated on the convex side and becomes slightly shortened in a certain middle calicular level (Fig. 16G). Contratingent minor septa and the prominent antiseptal triade are regularly developed. Septal flanks have no spiny ornament or granulations as in Cyathocarinia; distal septal margins are smooth (lamellar microstructure).

Discussion: The taxonomy within the genus is even recently discussed in an extreme controversial manner. The old opinion of Schindewolf (1951: 101) with a very broad concept of one cosmopolitic species Cyathaxonia cornu Michelin, 1847 throughout the entire Early Carboniferous was published without serious proof. Reliable discrimination of species, often with only minor diagnostic features, requires intensive studies of populations through time and space; collections from the lower Hastarian in Germany 

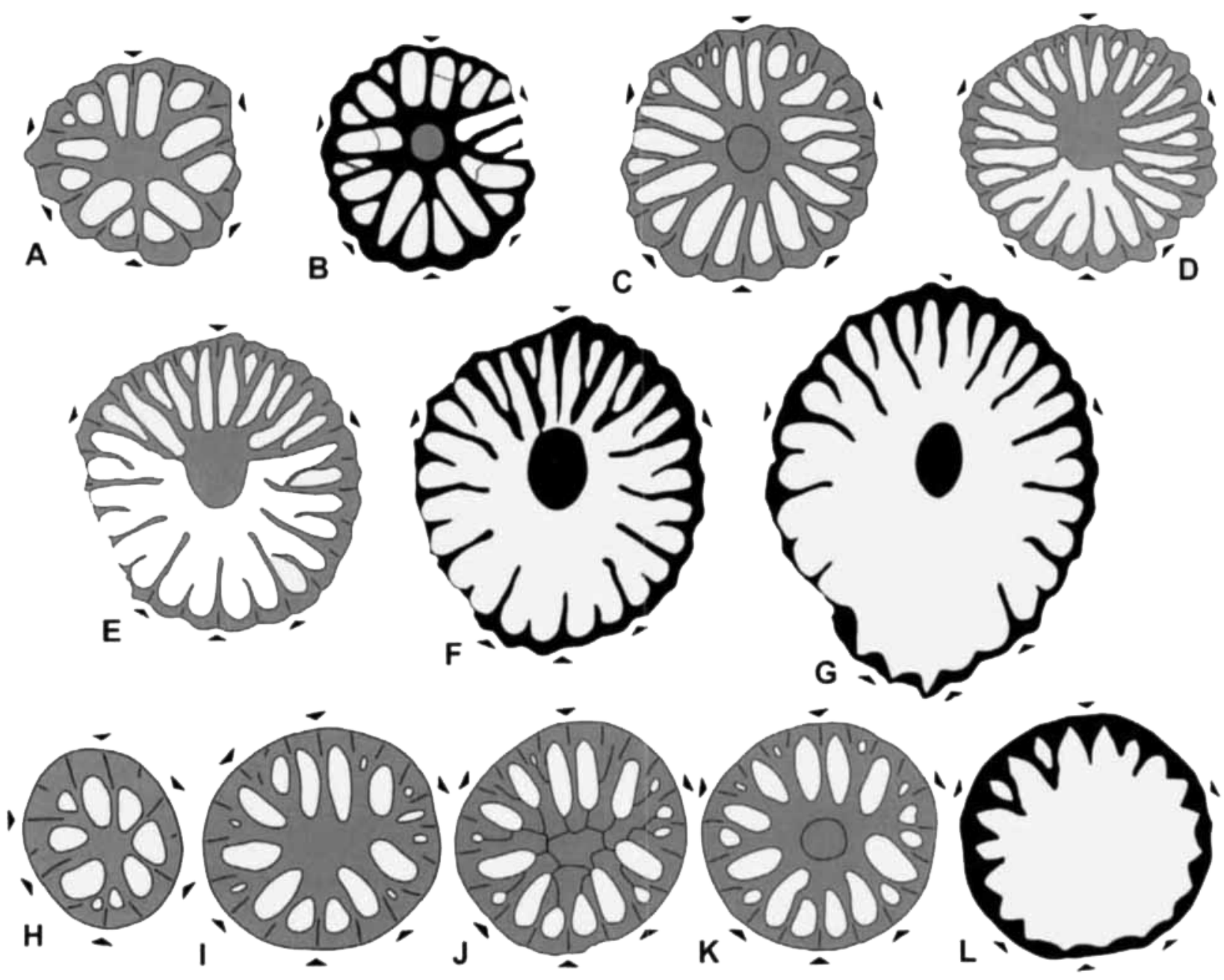

Fig. 16. Cyathaxonia sp. B. A-G. MB.K.673; Hasselbach N, Acutimitoceras acutum Zone, bed 81; serial cross sections 10-8, 6, 4, 2, 1, $\times 24$ (A, subtabular), $\times 18$ (B-C, calicular base), and $\times 12$ (D-G, calicular). (see PI. 4, figs 3-4). H-L. MB.K.674; Hasselbach N, Paprothites dorsoplanus Zone, bed 65; serial cross sections 8 (subtabular) and 4-1 (calicular), $\times 30$ (H), $\times 24$ (I), and $\times 20$ (J-L). (see Pl. 4, fig. 2).

\begin{tabular}{|c|c|c|c|}
\hline Septal formulae & 1 & $2 \mid 2$ & 3 \\
\hline of MB.K.673 & \begin{tabular}{l|l}
2 & 2
\end{tabular} & \begin{tabular}{l|l}
3 & 3
\end{tabular} & \begin{tabular}{l|l}
4 & 4
\end{tabular} \\
\hline $\mathrm{n}$ & 10 & 14 & 18 \\
\hline $\mathrm{N}$ & 15 & $21-14$ & 28 \\
\hline $\mathrm{D}(\mathrm{mm})$ & 1.2 & $1.7-1.9$ & $2.9-3.8$ \\
\hline Fig. & A & $\mathrm{B}, \mathrm{C}$ & $D-G$ \\
\hline
\end{tabular}

indicate four taxa of both Cyathaxonia and Cyathocarinia, all clearly different from the late Tournaisian (Ivorian) type species.

Family Petraiidae Koninck, 1872

Subfamily Bathybalvinae Weyer, 1991

\section{Bathybalva Weyer, 1981}

\section{Bathybalva crassa Weyer, 1981}

Fig. 17A-J, Pl. 4: 1

\footnotetext{
* 1981a Bathybalva crassa n. sp. - Weyer: 112, pl. 1: figs 7-18, pl. 4: figs 1-20, pl. 5: figs 1-26.

1984a Bathybalva crassa Weyer, 1981 - Weyer: 22, fig. 5/3.

2001 Bathybalva crassa Weyer, 1981 - Weyer: 70, fig. 3/ $4 a-c$.
}

\begin{tabular}{|c|c|c|c|}
\hline Septal formulae & $1|1|$ & \begin{tabular}{l|l}
1 & 2 \\
\end{tabular} & \\
\hline of MB.K.674 & \begin{tabular}{l|l}
2 & 2 \\
\end{tabular} & \begin{tabular}{l|l}
3 & 3
\end{tabular} & 3 \\
\hline $\mathrm{n}$ & 10 & 13 & 14 \\
\hline $\mathrm{N}$ & 13 & 19 & 20 \\
\hline $\mathrm{D}(\mathrm{mm})$ & 0.8 & 1.3 & $1.6-1.7$ \\
\hline Fig. & $\mathrm{H}$ & I & $\mathrm{J}-\mathrm{I}$ \\
\hline
\end{tabular}

Material: One specimen (MB.K.671; 13CS (P) + 2R; coll. Weyer 1994) from Hasselbach $N$ (bed 76), early Tournaisian ("Gattendorfia Stufe"), Acutimitoceras acutum Zone.

Description: The small long-conical and cornute coral ( $\mathrm{L}$ ca. $9.5 \mathrm{~mm}$, upper D $5.0 \mathrm{~mm}$ ) is embedded in sediment; its archaeotheca was not seen directly and could bear no or only very weak longitudinal ribbing. The septal apparatus within the very deep calice is radially grouped and axially united either directly (in the youth) or at maturity around a very small aulos-like calicular pit. Septa show a pinnate and pseudofossular arrangement at the insertion points. The length of the cardinal septum, located on the convex side, equals that of other major septa; the seeming shortening of the antiseptum 


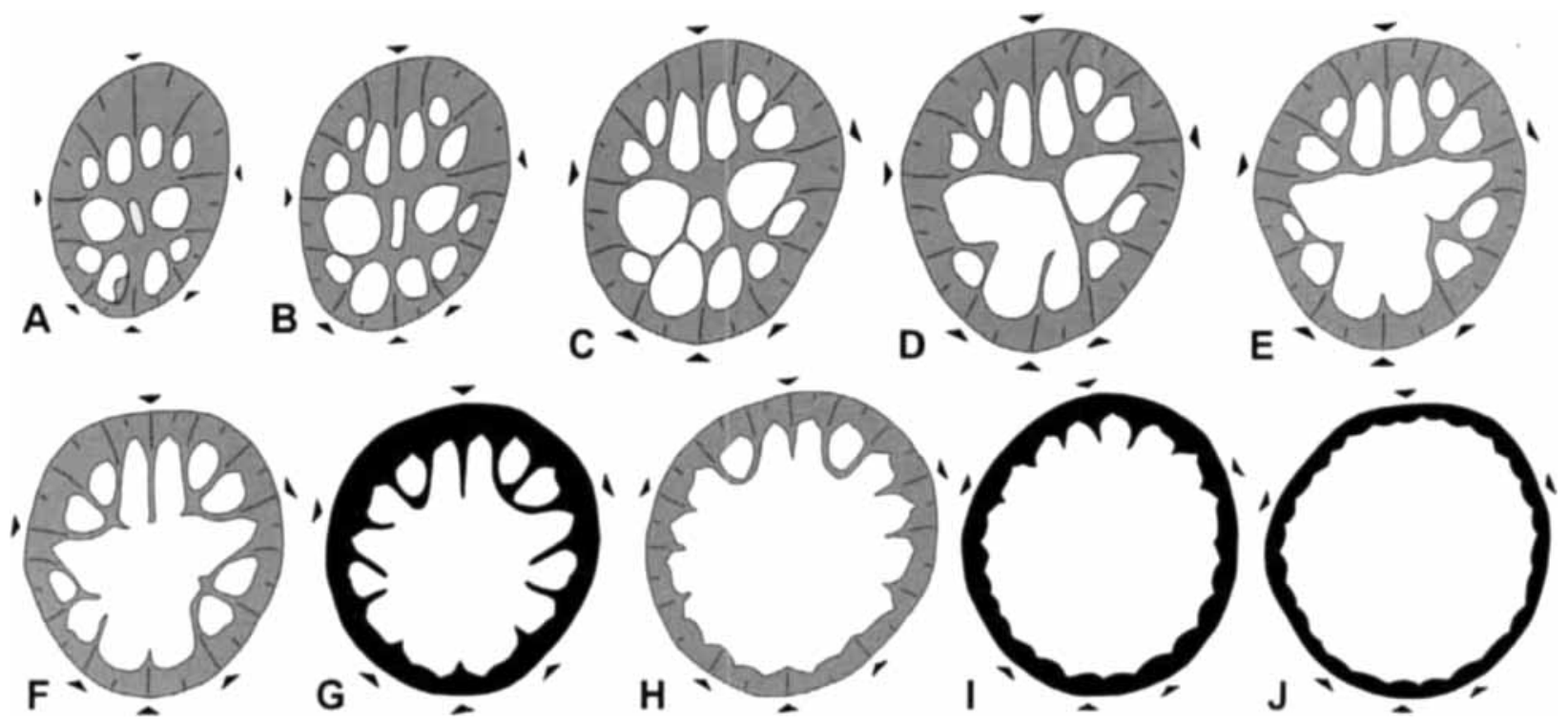

Fig. 17. Bathybalva crassa Weyer. 1981. MB.K.671: Hasselbach N. Acutimitoceras acutum Zone, bed 76; calicular cross sections $13-12,10-5,3-2, \times 12(\mathbf{A}-\mathbf{D}), \times 11(\mathbf{E}), \times 10(\mathbf{F}-\mathbf{H}), \times 9(\mathbf{I})$. and $\times 8(\mathbf{J})$; the aulos of A-B is in subtabular position. (see Pl. 4, fig. 1).

\begin{tabular}{|c|c|c|c|c|}
\hline Septal formulae & & $2 \mid 2$ & $\begin{array}{l:l}3 & 3 \\
\end{array}$ & $\begin{array}{l}3 \\
3\end{array}$ \\
\hline MB.K.671 & \begin{tabular}{l|l}
3 & 3
\end{tabular} & \begin{tabular}{l|l}
3 & 4
\end{tabular} & $\begin{array}{l:l}3 & 4\end{array}$ & $4 \mid 4$ \\
\hline $\mathrm{n}$ & 14 & 15 & 17 & 18 \\
\hline $\mathrm{N}$ & $20-23$ & 25 & 27 & 28 \\
\hline $\mathrm{D}(\mathrm{mm})$ & $1.6-1.9$ & 2.4 & $2.5-2.9$ & $3.1-3.8$ \\
\hline Fig. & $A, B$ & C & $\mathrm{D}-\mathrm{G}$ & $\mathrm{H}-\mathbf{J}$ \\
\hline
\end{tabular}

(Fig. 17E, F) may be at least in part a function of corallum curvature and plane of serial sectioning (Weyer 1973a: fig. 4), which is exercised parallel to growth rugae or parallel to the upper calicular margin. Short minor septa are active in the distal calice (Fig. 17J) and later disappear in the thickening wall after some contracline-like melting with their neighbouring major septa. There is no antiseptal triade. Peripheral tabulae are not seen and could be really absent in such a small coral. The terminal interior thickening of the archaeotheca amounts less than in the type series, but this feature may be variable during ontogeny (Weyer 1981a: pl. 4: figs 1-12).

Discussion: The hitherto not seen presence of a small aulos (with one tabula) at the central calicular base supports the already postulated relationships with the Neaxon group (Petraiinae). The subfamily Bathybalvinae (including Pseudopetraia Soshkina, 1951, Famaxonia Weyer, 1971. and Asthenophyllum Grubbs, 1939) has priority over its synonym Pseudopetraiidae Fedorowski, 1991 (published in September $20^{\text {th }}$, whereas Weyer 1991 was available already in April). Earlier members of this at the moment rather rare taxon, the ancestral group of Petraiidae, remained poorly known and should be expected in much greater diversity during all the Devonian and even the Silurian. But there is only one big collection (Weyer 2001) in our hands, a new species of Pseudopetraia from late Eifelian limestones of the Tafilalt (Morocco).

Distribution: This characteristic species of the German basal Tournaisian "Gattendorfia Stufe" was recorded mainly from the Thuringian Mountains (Saalfeld) and also from the Rhenish Mountains (Ober-Rödinghausen railway cut) in the Acutimitoceras acutum, Paprothites dorsoplanus, and Pseudarietites westfalicus Zones.

Subfamily Petraiinae Koninck, 1872

\section{Neaxon Kullmann, 1965}

\section{Neaxon regulus Richter, 1848}

Figs 18A-O, 19, Pl. 3: 1-6

\footnotetext{
* 1848 Petraia regulus [n. sp.] - Richter: 38, pl. 5: figs 134136.

1969 Neaxon bulloides n.sp. - Różkowska: 752, pl. 1: fig. $2 a-b$.

1971 Neaxon regulus (Richter, 1848) - Weyer: 295, pls 1-6.

1981b Neaxon regulus (Richter, 1848) - Weyer: 6, fig. 4, photo 3.

1984b Neaxon regulus (Richter, 1848) - Weyer: 6, 16, pl. 7: figs $1-15$.

2002 Neaxon regulus (Richter, 1848) - Berkowski: 20. pl. 15: figs 2-3.
} 

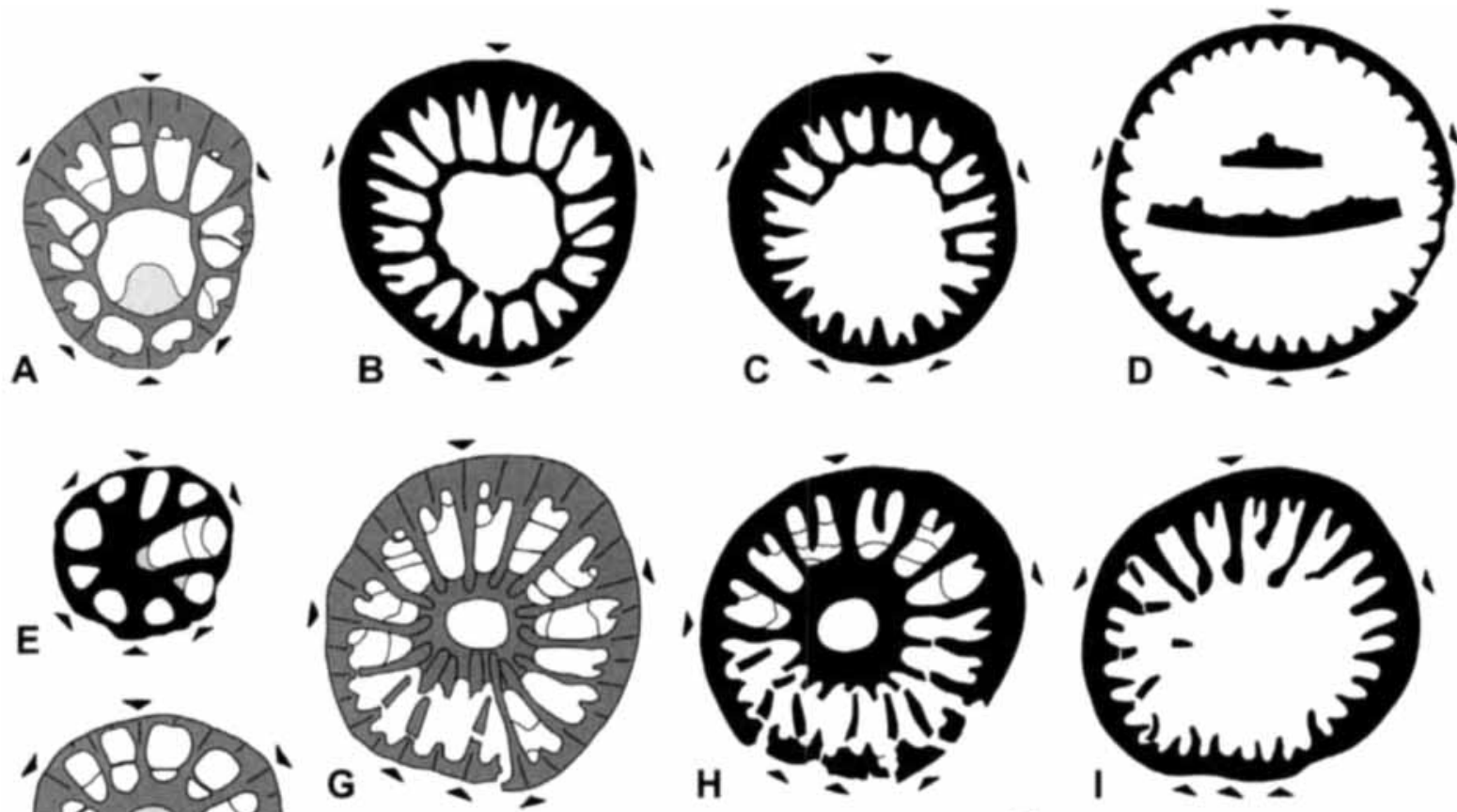

$\mathbf{F}$
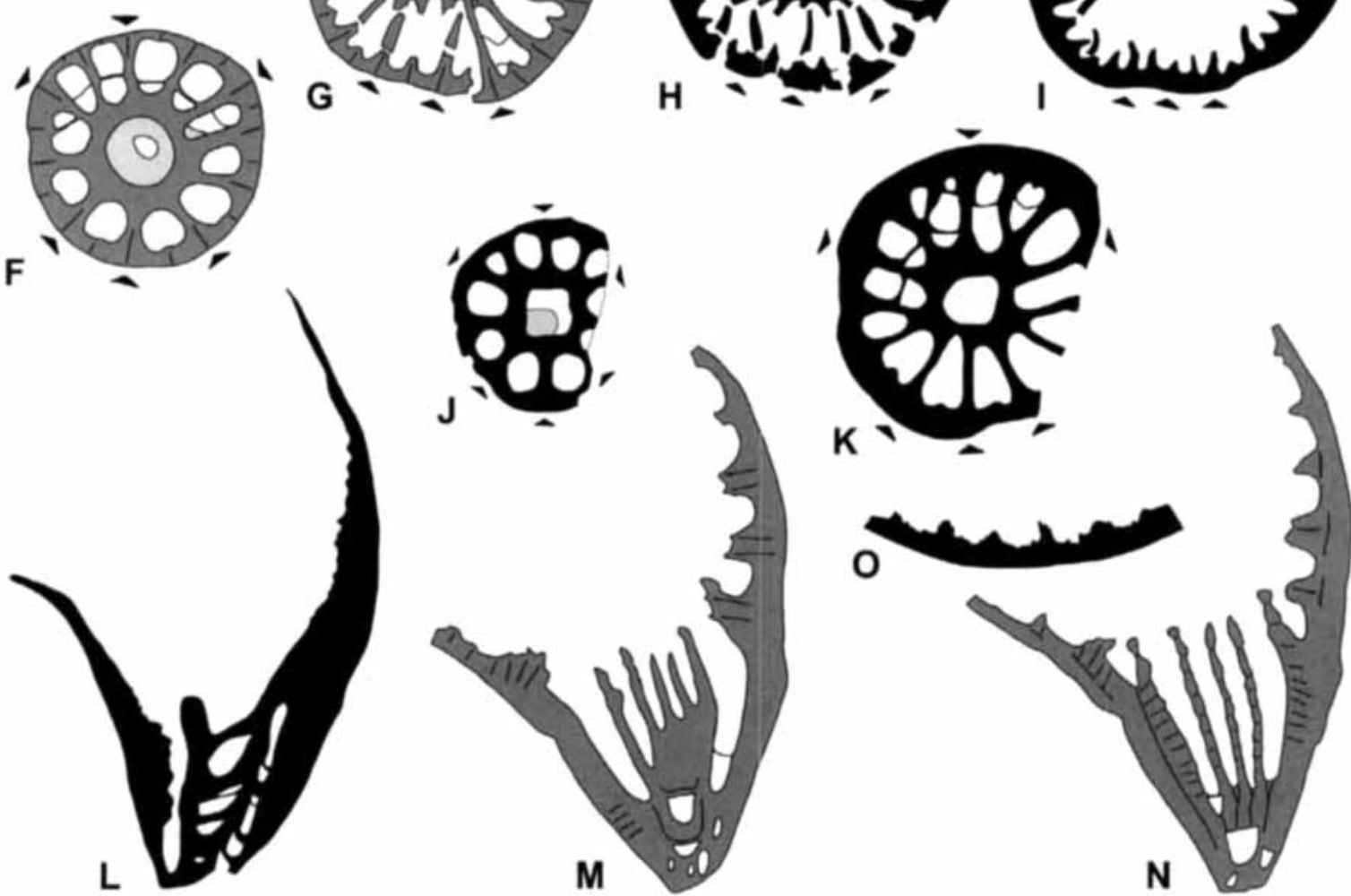

Fig. 18. Neaxon regulus (Richter, 1848). A-D. MB.K.666; Hasselbach N. Parawocklumeria paradoxa Zone; calicular cross sections $10, \times 12,7, \times 6,5, \times 5$, and $2, \times 4$ (with included multitrabecular septal details from cross section $1, \times 10$ ). E-I. MB.K.663; Hasselbach N, Wocklumeria sphaeroides Zone; subtabular (E, F) and calicular cross sections $16, \times 20,13, \times 15,10$, $\times 8,8, \times 6$, and 5, $\times 5$. (see Pl. 3, figs 3-5). J-K. MB.K.662; - Hasselbach S, middle part of lower "Wocklumeria Stufe"; subtabular and calicular cross sections $12, \times 12$, and $10, \times 10$. (see Pl. 3, figs 1-2). L. MB.K.664; Hasselbach N, uppermost Wocklumeria sphaeroides Zone; longitudinal section 2, $\times 6$. M-O. MB.K.665; Hasselbach N, lower Wocklumeria sphaeroides Zone; longitudinal sections $4,3, \times 6$, cross section 1 (upper margin of calice, with multitrabecular septal microstructure), $\times 8$. (see Pl. 3, fig. 6)

Septal formulae MB.K.666

n

N

$\mathrm{D}(\mathrm{mm})$

Fig.

\begin{tabular}{c|c}
2 & 2 \\
\hline 4 & 4 \\
16 \\
24 \\
2.2 \\
A
\end{tabular}

\begin{tabular}{c|c}
3 & 3 \\
\hline 5 & 4 \\
19 \\
31 \\
5.5 \\
B
\end{tabular}

\begin{tabular}{c|ccc|c}
3 & 3 & & 4 & 3 \\
\hline 5 & 5 & & 5 & 6 \\
20 & & 22 \\
32 & & 36 \\
6.5 & & 9.7 \\
$\mathrm{C}$ & & $\mathrm{D}$
\end{tabular}

Septal formulae MB.K.678

$\mathrm{n}$

N

$\mathrm{D}(\mathrm{mm})$

Fig.

\begin{tabular}{c|c}
1 & 2 \\
\hline 3 & 3 \\
13 \\
18 \\
1.0 \\
$\mathrm{E}$
\end{tabular}

\begin{tabular}{c|c}
2 & 2 \\
\hline 3 & 4 \\
15 \\
22 \\
1.8 \\
F
\end{tabular}

\begin{tabular}{ccc|c}
3 & 3 & 3 & 4 \\
\hline $4 \mid 5$ & & 5 & 5 \\
19 & 21 \\
30 & 34 \\
$4.5-6.1$ & 7.5 \\
G, H & I
\end{tabular}

Septal formulae
MB.K. 680
n
N
D $(\mathrm{mm})$
Fig.

\begin{tabular}{c|cc|c}
2 & 2 & 2 & 3 \\
\hline 3 & 3 & 4 & 3 \\
14 & 16 \\
20 & 26 \\
1.9 & 3.4 \\
$\mathrm{~J}$ & $\mathrm{~K}$
\end{tabular}


Material: Seven specimens from the localities Hasselbach N (2-7) and Hasselbach S (1): lower "Wocklumeria Stufe" (1) and upper "Wocklumeria Stufe":

MB.K.662; 13CS (12P, 1TS) + 2R; Fig. 18J-K, PI. 3: 1-2 (bed 14, coll. R.T. Becker 1994). Mentioned in R. T. Becker (1996: 21 - Neaxon regulus)

MB.K.663; 18CS (16P, 2TS) + 2R: Fig. 18E-I, Pl. 3: 3-5 (interval of bed 98-114, Wocklumeria sphaeroides Zone. coll. R. T. Becker 1987). Mentioned in R.T. Becker (1988: 198 small solitary coral).

MB.K.664; 3LS (P) + 1R: Fig. 18L (bed 114, Wocklumeria sphaeroides Zone, coll. R. T. Becker 1996).

MB.K.665; 1CS (P) + 3LS (2P, 1TS) + 2R; Fig. 18M-O. Pl. 3: 6 (bed 94, Wocklumeria sphaeroides Zone. coll. Weyer 1994). MB.K.666; 10CS (9P, 1TS): Fig. 18A-D (bed 90, Parawocklumeria paradoxa Zone. coll. Weyer 1994). Mentioned in Weyer (1995: 106: fig. 1 - Neaxon regulus)

MB.K.678: 2R (bed 92, Wocklumeria sphaeroides Zone, coll. Weyer 1994).

MB.K.679; 2R (bed 109, Wocklumeria sphaeroides Zone. coll. Weyer 1994).

Description: Characteristic features of juvenile, middle and mature stages of the cornute corals are visible in the cross sections - a stereothecate aulos of middle to wide size, comparatively thick septa in radial position, the development of minor septa, an unshortened cardinal septum at the convex side of corallum, and septal formulae. Upper septal margins bear very coarse monacanth trabeculae (spines). Multitrabecular spinose ornament is present just at the distal calicular rim (Fig. 18D, L-O). The uppermost calicular phase with "third order septa" (of meiosepta type - Weyer 1984b: 6) is missing in the available cross sections.

Distribution: This well known species is the most common late Famennian ("Clymenia and Wocklumeria Stufe") rugose coral of the cold water Cyathaxonia facies in Central Europe. New records (unpublished Weyer collection 1999-2000) from the "Wocklumeria Stufe" in the Madène El Mrakib section (Korn 1999: 149, R. T. Becker et al. 2002: 162) extend the area of distribution to Morocco (southern Ma'der, AntiAtlas).

In the type region of Saalfeld (Thuringian Mountains), the available material of the first revision (Weyer 1971; 54 specimens) has been augmented by additional 139 specimens from new collections of Bartzsch and Weyer from 1976 to
1991. Figure 19 shows their occurrence throughout the Breternitz Member, from the Clymenia laevigata Zone to the top of the Wocklumeria sphaeroides Zone immediately below the black shale that represents the global Hangenberg event.

\section{Neaxon n. sp.}

Fig. 20A-D, Pl. 3: 8-9

Material: One specimen (MB.K.672; 7CS [6P, 1TS]; coll. Weyer 1993) from the Hasselbach 1/1987 borehole (depth $35.00-35.05 \mathrm{~m}$ ), middle part of the "Lower Wocklumeria Stufe" (bed 28).

Description: The corallum has $7 \mathrm{~mm}$ in length and $6 \mathrm{~mm}$ in distal diameter; here with damaged broken septa. It has a straight conical shape with a big basal talon $(2.5 \times 4 \mathrm{~mm})$, which indicates a juvenile cornute configuration with the cardinal septum at the convex side. The archaeotheca bears fine growth rugae and very weak longitudinal septal furrows. The locally weathered cast shows coarse monacanth trabecular spines at the septal margins of the distal calice. The cross sections with their radially disposed septa and a large regular aulos demonstrate the typical Neaxon structure. Putatively "contratingent minor septa" are nothing but new major septa at the four insertion points. There occur distant simple convex tabulae.

Discussion: The undescribed species can not be named on the basis of this single, not well preserved specimen, but will be officially established in near future on the base of several conspecific corals from the "Wocklumeria Stufe" of Saalfeld (Thuringia). Differences to Neaxon regulus (Richter, 1848) are the straight growth of the conical corallum with a short cornute phase only near the juvenile fixing talon, the comparatively thinner major septa, and the much longer minor septa in maturity. The latter feature resembles Neaxon bartzschi Weyer, 1978, which differs in its strong axial thickening in all long major septa.

Plate 3. Corals from the Late Famennian ("Wocklumeria Stufe") of Hasselbach section. 1-6. Neaxon regulus (Richter, 1848). 1-2. MB.K.662: Hasselbach $S$, lower "Wocklumeria Stufe": side view of corallum, $\times 4$, cross section $11, \times 12$. (see Fig. 18J-K). 3-5. MB.K.663: Hasselbach N. Wocklumeria sphaeroides Zone; side view of corallum, $\times 4$, cross sections 12 and $8, \times 15$ and $\times 7$. (see Fig. 18E-I). 6. MB.K.665; Hasselbach N, Wocklumeria sphaeroides Zone; longitudinal section 4, $\times 7$. (see Fig. 18MO). 7. Famennelusma rhenanum Weyer, 1973; MB.K.680; Hasselbach S, lower "Wocklumeria Stufe"; cross section near the calicular base, $\times 5$. (see Fig. 22A-D). 8-9. Neaxon n. sp. W: MB.K.672: Hasselbach 1/1987 borehole, lower "Wocklumeria Stufe"; subtabular (8) and partly calicular (9) cross sections 7 and 3, $\times 10$. (see Fig. 20A-D). 10. Gorizdronia sp. A; MB.K.681; Oese, upper "Wocklumeria Stufe"; cross section $8, \times 8$. (see Fig. 25A-H). 11-15. Hillaxon hassel n. sp.; holotype MB.K.678; Hasselbach S, lower "Wocklumeria Stufe"; subtabular cross sections 14, $\times 8,6$ and 3, $\times 7$; median longitudinal sections 13 and $11, \times 7$. (see Fig. $21 \mathrm{~A}-\mathrm{F}$ ). 

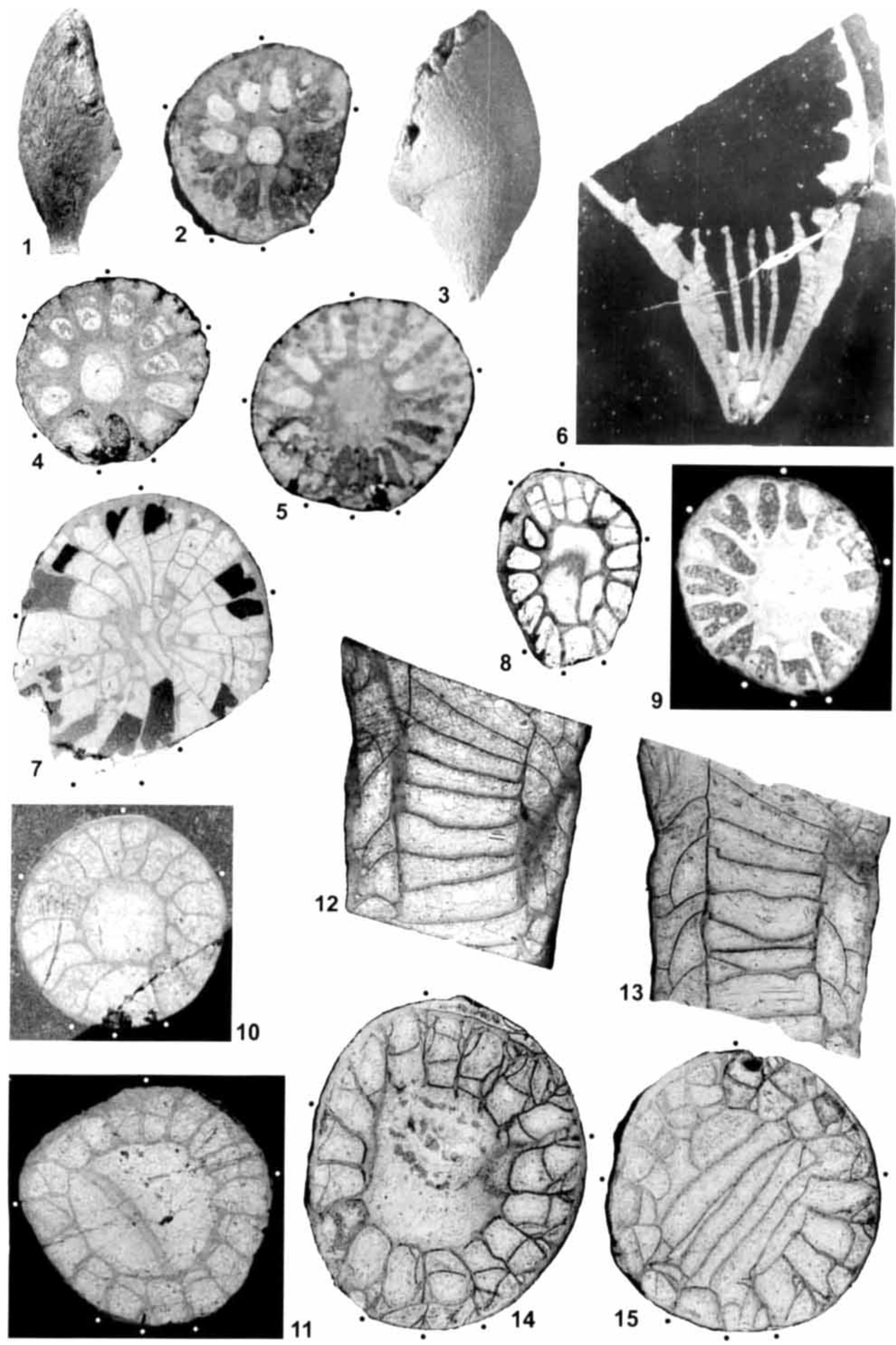


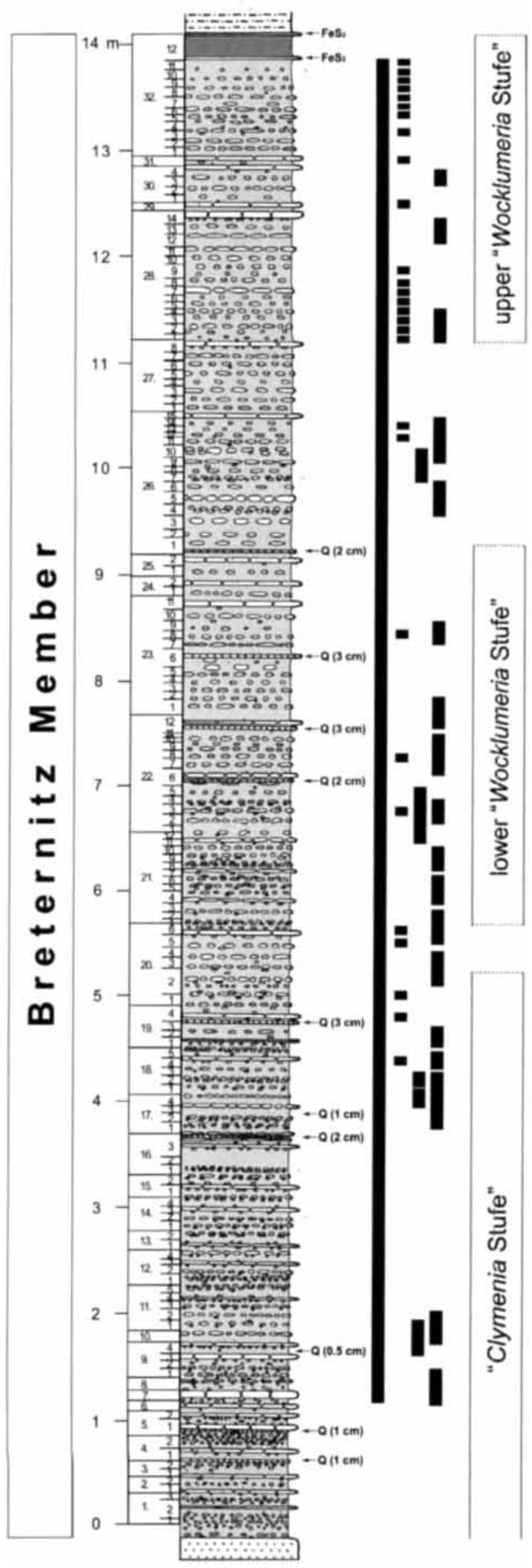

\section{Hillaxon Różkowska, 1969}

\section{Hillaxon hassel n. sp.}

Fig. 21 A-F, Pl. 3: 11-15

Holoty pe: specimen MB.K.678; 10CS (7P, 3TS) + 4LS (2P, 2TS); coll. R. T. Becker 1999.

Derivation of name: After the Hassel rivulet on which bank the holotype was collected.

Type locality and horizon: Hasselbach $S$ without precise bed indication: upper Famennian Wocklum Limestone, lower part of the "Wocklumeria Stufe".

Diagnosis: Slender conical Hillaxon with 34 septa at $6-8 \mathrm{~mm} \mathrm{D}$ and many simple dissepiments, often covering the septal flanks, in the adult stage.

Description: The only available specimen is a slightly cornute conical corallum with remarkable torsion, preserved without tip and upper calice (L $22 \mathrm{~mm}$, lower D $5.7 \mathrm{~mm}$, upper D $8 \mathrm{~mm}$ ). In maturity, the cardinal septum is situated at the concave side. The archaeotheca bears fine growth rugae and very weak, almost invisible longitudinal septal furrows. The preserved adult part shows 34 septa without new insertions; therefore the difficult identification of six protosepta used mainly the starting trend towards a biform tabularium. All major septa (except for the four short ones at the insertion points according to the law of Kunth) are equal in length, in radial position, and axially united to form a regular wide aulos. This apparently starts as a stereotheca in the youth, later becoming cyathothecate, and being persistent up to the calice, but with some few repeated discontinuous phases caused by a weak amplexoid trend at maturity. Short minor septa are always visible; their apparent temporary local absence in some places of the cross sections is caused by the typical coarse monacanth septal microstructure of the Neaxon group.

Distant horizontal to slightly concave tabulae occur in the central aulos. At the periphery, there

Fig. 19. Distribution of Neaxon regulus (Richter, 1848) in the upper Famennian Breternitz Member (Gleitsch Formation) near Saalfeld in Thuringia (south-eastern flank of Schwarzburg anticline).

Standard lithostratigraphy of cypridinic shales with layers of limestone beds and nodules (former upper Clymeniid beds, subdivided into 152 beds and grouped as 32 units, measured by Bartzsch and Weyer 1988 - Bartzsch et al. 1993). $Q=$ thin quartzitic horizons; at top (32.12) black shale of Hangenberg event (Bartzsch et al. 1998). The total vertical range of the Rugosa species (left black line) is based on rather well stratified collections obtained from precise single beds (second row of black dots) or from little thicker intervals comprising $2-6$ beds (right two rows). 

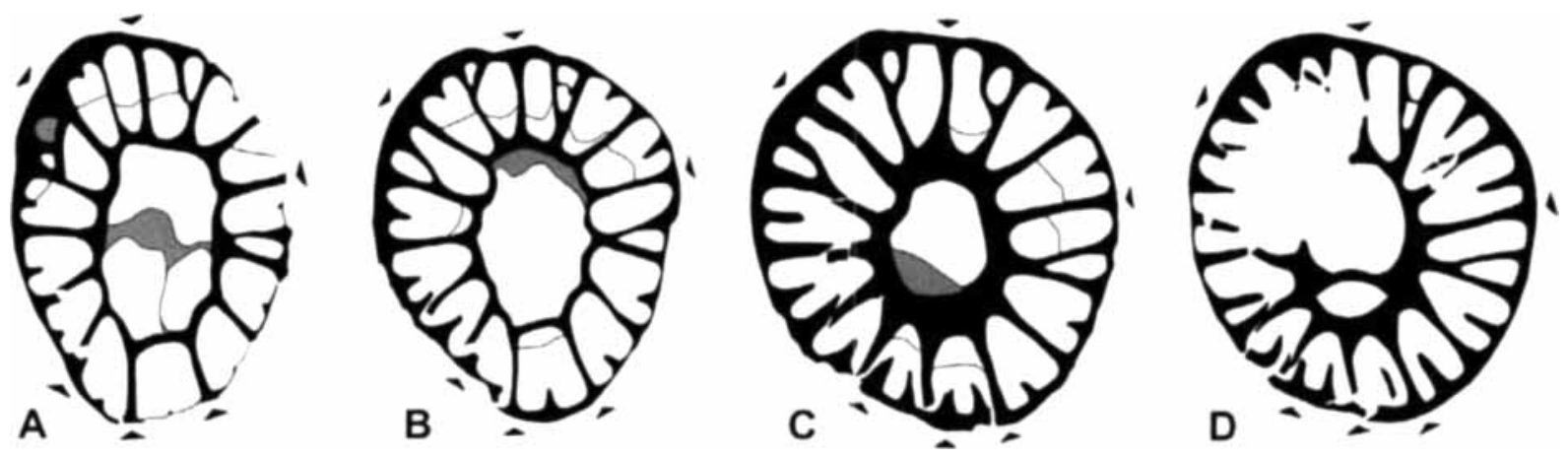

Fig. 20. Neaxon n. sp. MB. K.672; Hasselbach 1/1987 borehole, middle part of lower "Wocklumeria Stufe"; subtabular (A) and calicular (B-D) cross sections $6, \times 11,5$ and $3, \times 10,1, \times 8$. (see Pl. 3, figs $8-9$ ).

\begin{tabular}{lcc|c} 
Septal formulae & 1 & 3 & $\frac{2}{3} \mid 3$ \\
MB.K.672 & 5 & 4 & 18 \\
n & 17 & 28 \\
N & 27 & $2.8 \times 3.2$ & $2.8 \times 3.2-4.9 \times 5.1$ \\
D $(\mathrm{mm})$ & A & B - D
\end{tabular}
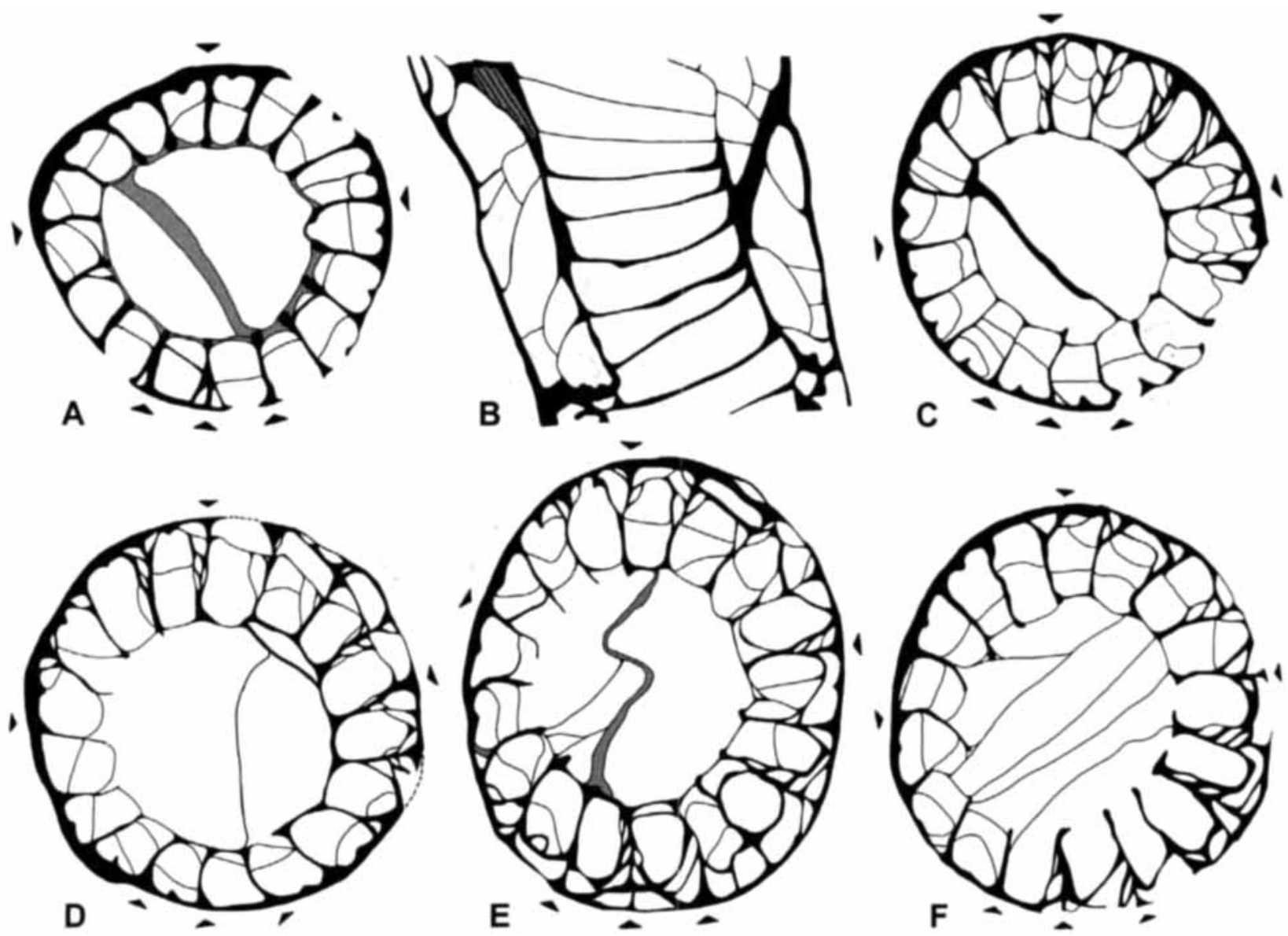

Fig. 21. Hillaxon hassel n. sp. holotype MB.K.678; Hasselbach S, lower "Wocklumeria Stufe"; subtabular cross sections 14, 9, 7, $5,4, \times 8(\mathrm{~A})$ and $\times 7(\mathrm{C}-\mathrm{F})$; median longitudinal section 12, $\times 7$. (see Pl. 3, figs 11-15).

\begin{tabular}{|c|c|}
\hline Septal formulae & \begin{tabular}{l|l}
4 & 4
\end{tabular} \\
\hline MB.K.678 & \begin{tabular}{l|l}
4 & 5
\end{tabular} \\
\hline $\mathrm{n}$ & 21 \\
\hline N & 34 \\
\hline $\mathrm{D}(\mathrm{mm})$ & $5.8-7.1 \times 7.6$ \\
\hline Fig. & $A-F$ \\
\hline
\end{tabular}


are also few tabellae sloping downwards centrifugally against the wall. The oldest available stage (Fig. 21A) looks like a Neaxon, with just beginning formation of normal dissepiments, as seen in the upper left side (Fig. 21B). Their number increases terminally, particularly along the flanks of major septa in addition to those running parallel to the archaeotheca. There are only few presepiments (lonsdaleioid dissepiments; pl. 3: 14).

Discussion: This is the first record of the genus outside of Poland, where it is known by one species from the upper Famennian locality Gałęzice in the Holy Cross Mountains. This type species Hillaxon vesiculosus Różkowska, 1969 differs from the new species in its broad conical corallum, weaker minor septa, much narrower tabulae within the aulos, and nearly missing dissepiments on the septal flanks. Further comparisons would require a revision with better middle and mature series of cross sections which were not yet exercised in the Polish materials. The genus could not be found in the "Wocklumeria Stufe" of Thuringia, but we know two undescribed specimens of a third species from the Rhenish Mountains (Ober-Rödinghausen railway cut, and Reigern).

\section{Famennelasma Weyer, 1973}

A presumed synonymy with Friedbergia Różkowska, 1969 (discussion in Weyer 2000: 76) is not finally supported by the publication of a probable topotype of the type species Friedbergia bipartita Różkowska, 1969 from Kowala in the Holy Cross Mountains of Poland (Berkowski 2002: 21, pl. 13, fig. 3a-d). This specimen does not exhibit the typical Neaxon-like aulos in its juvenile stages.

\section{Famennelasma rhenanum Weyer, 1973}

Fig. 22A-D, Pl. 3: 7

* 1973b Famennelasma rhenanum sp. nov. - Weyer: 685,
pl. 1: 2a-e, pl. 2: 1a-h. Material: One specimen (MB.K.680; 6CS (5P, 1TS) + 4R; coll. R. T. Becker 1999) from Hasselbach S without precise bed indication; lower part of the "Wocklumeria Stufe".

Description: The poorly preserved, widely conical and straight corallum (L ca. $20 \mathrm{~mm}$, upper D $18 \times 11 \mathrm{~mm}$, lower D $8 \times 1 \mathrm{~mm}$, basal talon $11 \times 7 \mathrm{~mm}$ ) has the normal archaeotheca with fine growth rugae and very weak longitudinal septal furrows. The somewhat compressed distal part presents no dissepiments (in contrast to the neighbouring genus Czarnockia Różkowska, 1969); locally, in steinkern preservation, coarse monacanth trabecular spines are visible at the septal margins.

The septal apparatus is almost identical with that of the hitherto unique holotype from the Kellerwald region, Rhenish Mountains. Minor differences are slightly thinner major septa and thinner wall structures of the aulos; they are esti-
A
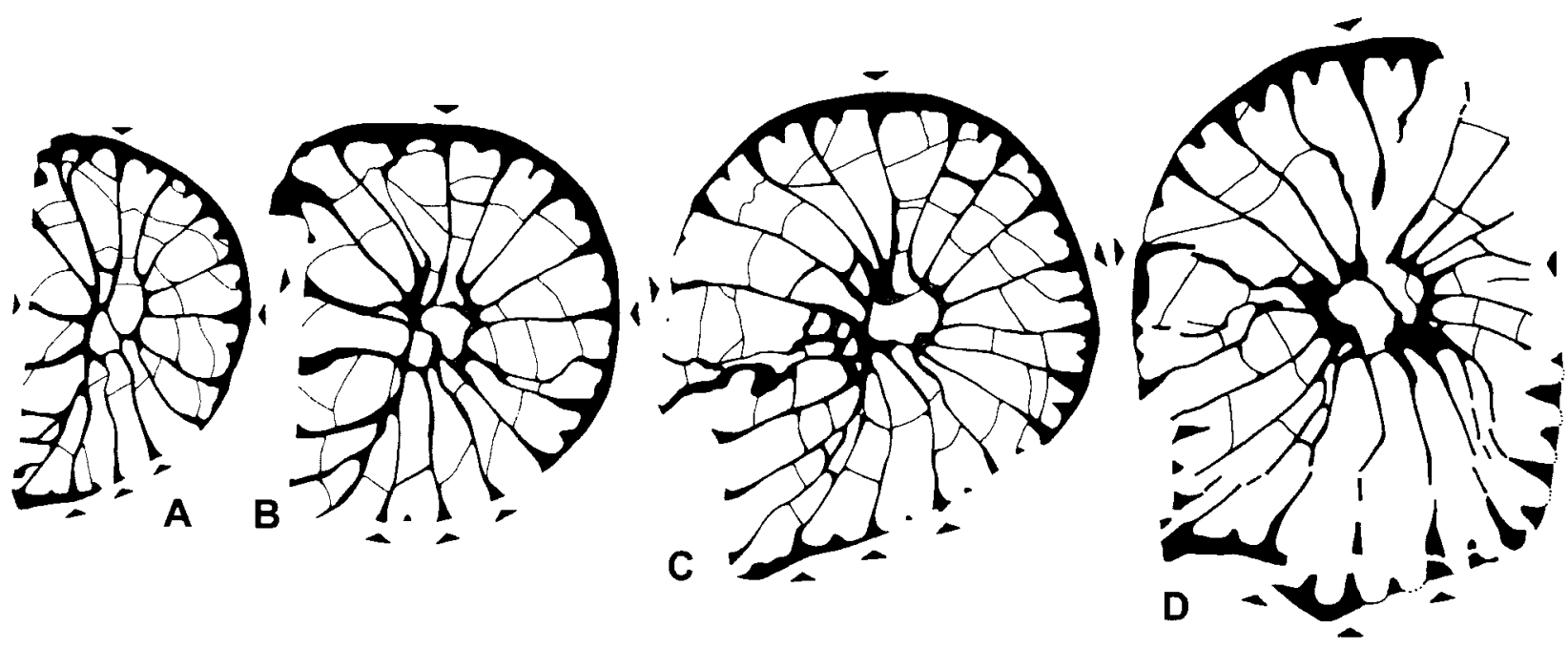

Fig. 22. Famennelasma rhenanum Weyer, 1973. MB.K.680; Hasselbach S. lower "Wocklumeria Stufe"; series of cross sections, subtabular (A, B), at calicular base $(\mathbf{C})$, and in the lower calice $(\mathbf{D}), \times 5(\mathbf{A}, \mathbf{C}, \mathbf{D})$ and $\times 6(\mathbf{B})$. (see Pl. 3: 7).

Septal formulae MB.K.680

n

$\mathrm{N}$

$\mathrm{D}(\mathrm{mm})$

Fig.

$-\frac{2}{6}+\frac{2}{4}$
21
34
7.6

A

\begin{tabular}{c:c}
4 & 4 \\
\hline 6 & 5 \\
23 \\
38 \\
7.5 \\
B
\end{tabular}

B

\begin{tabular}{cc}
$4 \cdot 4$ & $4: 5$ \\
\hline 77 & $7 \cdot 7$ \\
26 & 27 \\
44 & 46 \\
$9.4 \times 9.9$ & $9.4 \times 9.9$ \\
C & $D$
\end{tabular}

$\mathrm{D}$ 
mated here as normal intraspecific variation. The diagnostic important shortening of the cardinal septum above the calicular base just starts in the stage of Fig. 22D; it is situated in a true fossula (pl. 3: 7).

Discussion: The genus is widely distributed in Upper Famennian rocks from at least the Polish Holy Cross Mountains to Morocco, but most materials remained undescribed. A similar, probably conspecific specimen was recorded from Thuringia: Famennelasma sp. II (Weyer 1984a: fig. 4/2, "Wocklumeria Stufe").

Subfamily "Guerichiphyllinae Różkowska, 1969"

Hebukophyllum Liao \& Cai, 1987
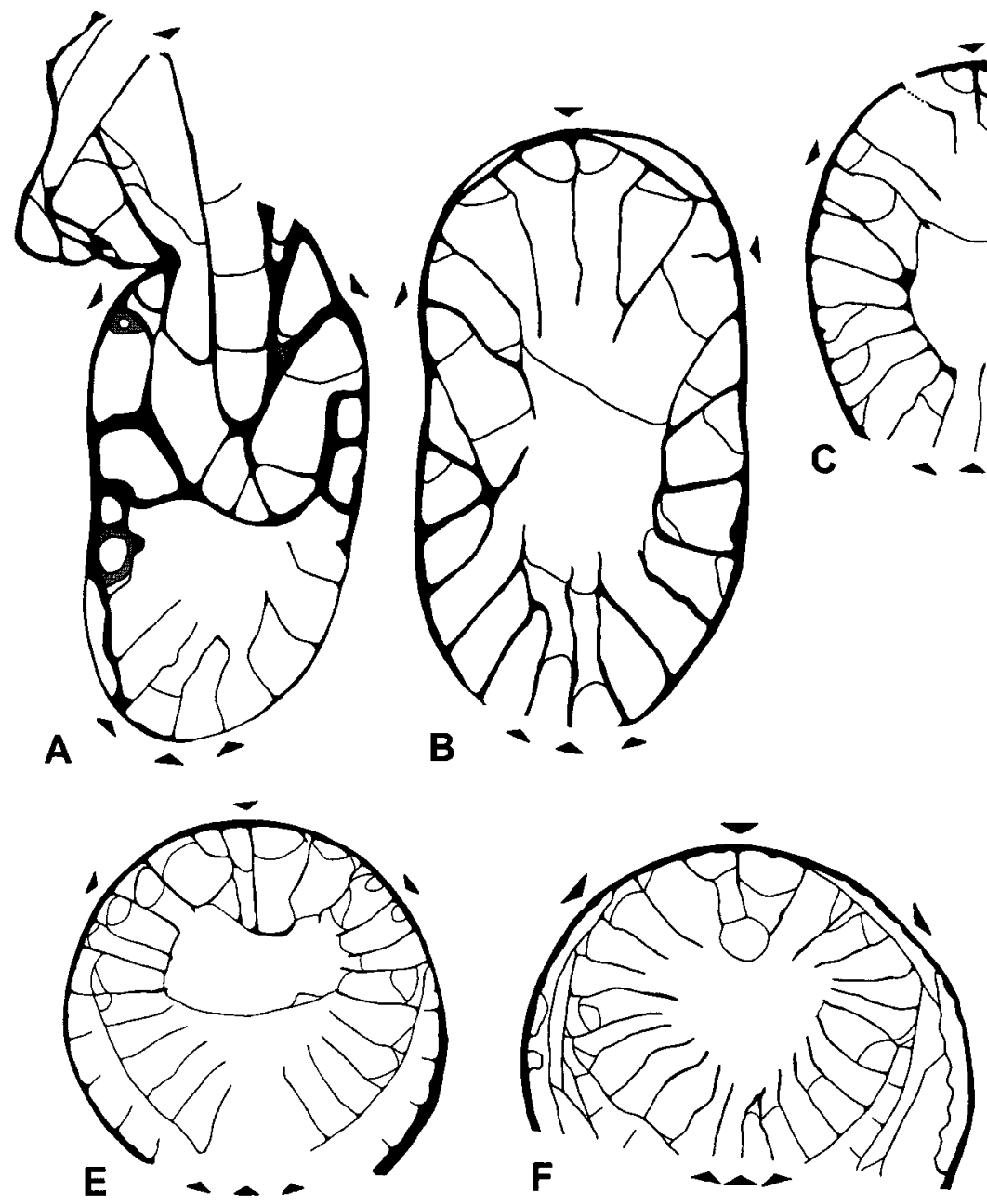

Hebukophyllum priscum (Münster, 1840)

Figs 23A-G, 24A-M, Pl. 4: 5-11

* 1840 Cyathophyllum priscum [n. sp.] - Münster: 114, pl. 9: fig. 12b-d (non 12a).

1982 Guerichiphyllum priscum (Münster, 1840) Bartzsch \& Weyer: 31 , fig. 10, pl. 6: figs $1-4$.

1994 Hebukophyllum priscum (Münster, 1840) - Weyer: 187 , figs $4 / 1-3,5 / 1-6,6 / 1-13$, pl. 1: figs $1-5$, pl. 2, figs $1-6$, pl. 3. figs $1-2$.

non 1996 Conilophyllum priscum (Münster, 1840) -- Poty \& Boland: 205, pl. 1: figs 1-3, pl. 2, fig. $1[=$ Conilophyllum tregaense (Poty, 1982)].

non 1997 Conilophyllum priscum (Münster, 1840) - Boland: 78, pl. 1, fig. 7: pl. 2, figs 2, 4 [= Conilophyllum tregaense (Poty, 1982)].

2001 Hebukophyllum priscum (Münster, 1840) - Weyer: 70 , fig. $3 / 1 a-b$.

Material: Two specimens from the "Gattendorfia Stufe": MB.K.638; 8 CS (6P, 2TS) + 1LS (P) + 3R; Fig. 23A-G, Pl. 4: 9-11; Hasselbach N (bed 83), Acutimitoceras prorsum Zone (Siphonodella sulcata Zone) (coll. Weyer 1994).
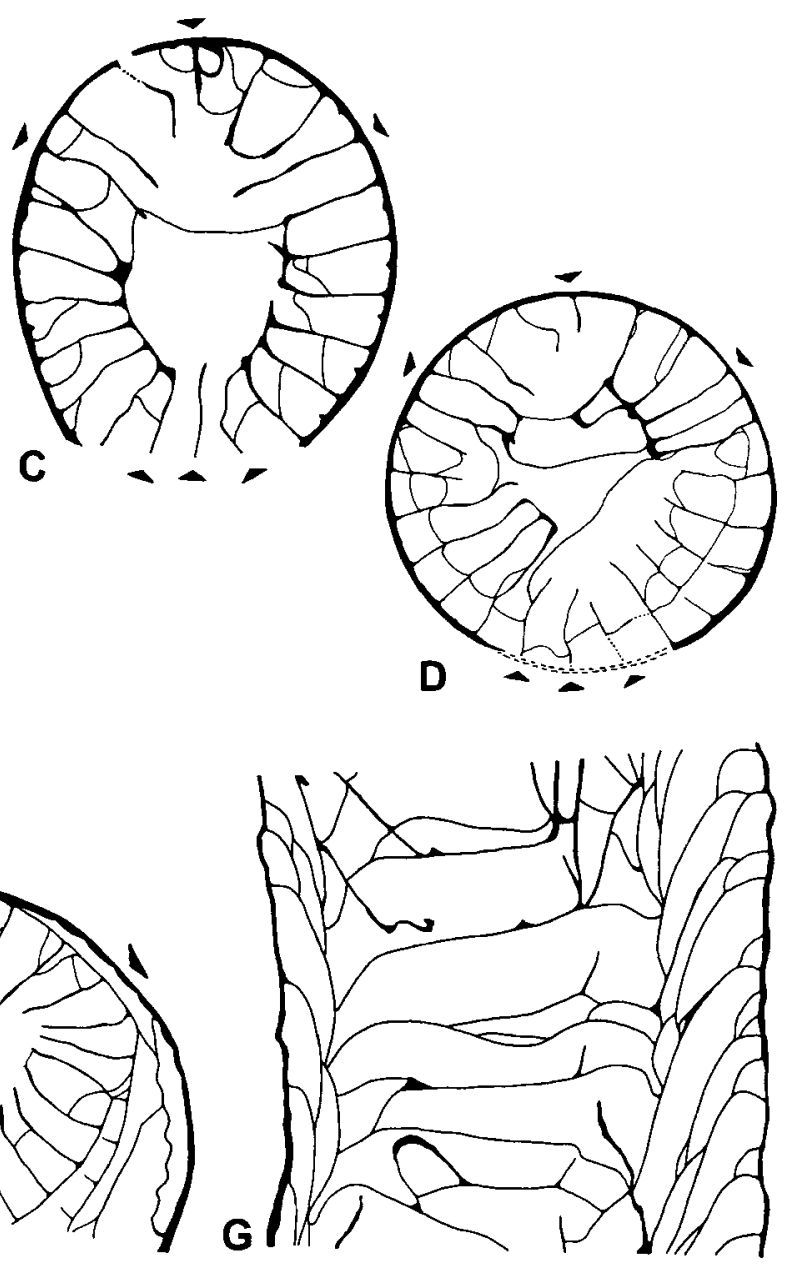

Fig. 23. Hebukophyllum priscum (Münster, 1840). MB.K.638; Hasselbach N, Acutimitoceras prorsum Zone, bed 83; A-F. subtabular serial cross sections $2,3,5-8, \times 6(\mathrm{~A}, \mathrm{~B}), \times 5(\mathrm{C})$, and $\times 4(\mathrm{D}-\mathrm{F})$; G. longitudinal section 9 , $\times 4$. (see Pl. 4: 9-11).

\begin{tabular}{lcc|c} 
Septal formulae & 3 & 3 & $\frac{3}{9}$ \\
MB.K.638 & 8 & 8 & 9 \\
n & 26 & 28 \\
N & 44 & 48 \\
D $(\mathrm{mm})$ & $5.2-10.0$ & $10.7-12.3$ \\
Fig. & A-D & E-F
\end{tabular}



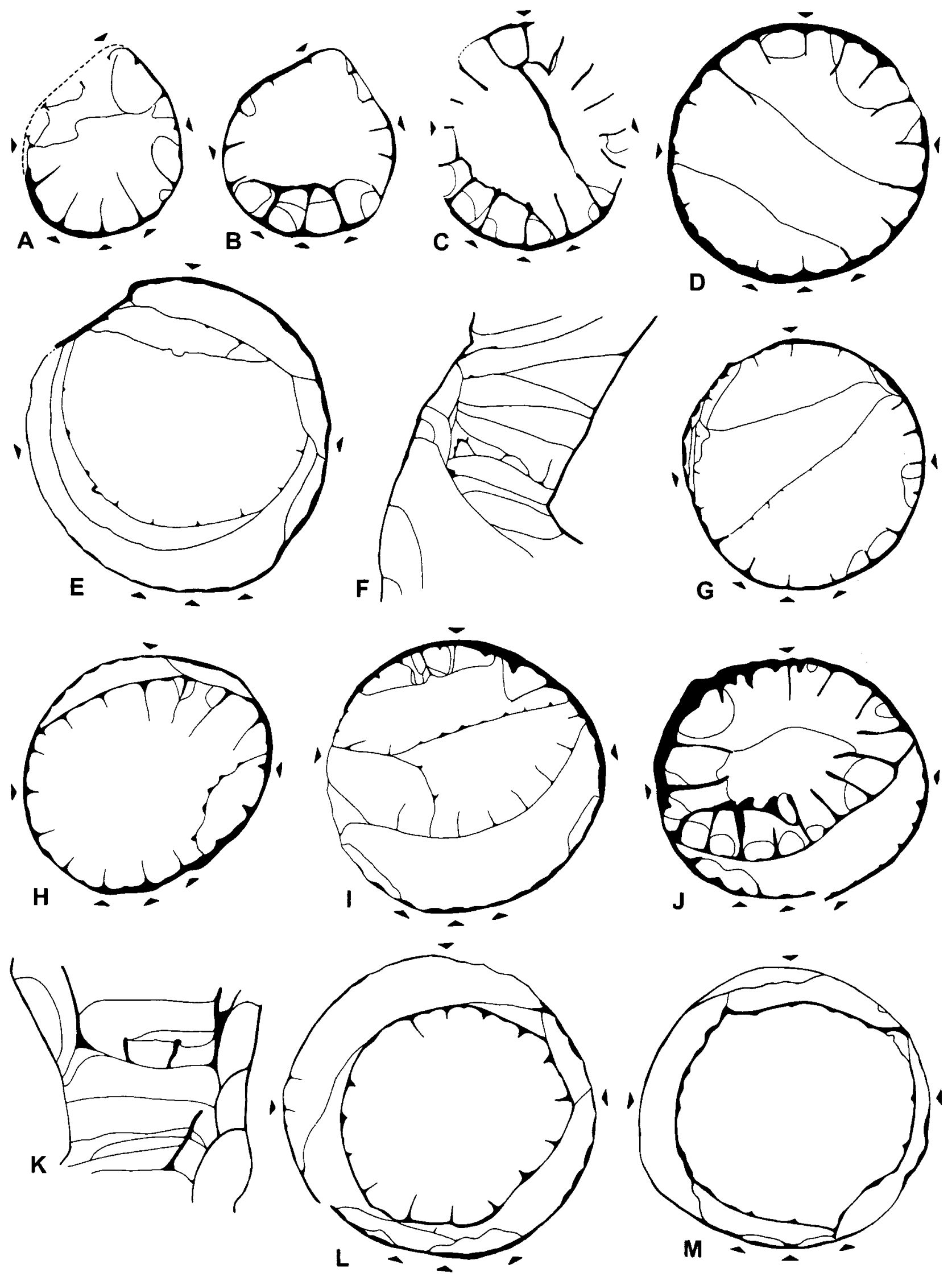
MB.K.676; 19CS (10P, 3TS) + 3LS (P) + 5R: Fig. 24A-M, Pl. 4: 5-8; Oese quarry (bed 22), Paprothites dorsoplanus Zone (lower Siphonodella duplicata Zone) (coll. Korn \& Weyer 2000).

Description: The first specimen (Fig. 23) was attached by a big talon to an adult shell of Acutimitoceras kleinerae Korn, 1984. It is characterised by well developed longer major septa nearly without an amplexoid or breviseptoid trend. Slight shortening of the cardinal septum and fossular structure become evident in Fig. 23F. This coral is comparable to the holotype and to most of the Thuringian specimens from Saalfeld.

The second specimen (Fig. 24) with at least six phases of rejuvenescence and a strong, several times changing amplexoid-breviseptoid trend resembles the holotype of Hebukophyllum xinjiangense Liao \& Cai, 1987. The variation of the septal apparatus, caused by some ecological stress, is enormous, and an orientation according to protosepta was possible only by means of many serial sections. The mature pleonophorous phase can be abandoned again, and growth continues with the ontogenetically earlier diaphragmatophorous style. Large lonsdaleioid dissepimental vesicles predominate. A conspecific interpretation of both records seems justified in view of the great variability known from the Rhenish Drewer locality and from Saalfeld material.

Discussion: The genus Hebukophyllum was estimated to be a synonym of Circellia Ye \& Wang, 1983 (Yu 1988: 188, Poty \& Boland 1996: 203, Berkowski 2002: 22). This is quite improbable in view of the recent revision (Liao \& Soto 2001: type series of the late Tournaisian Circellia planotabulata Ye \& Wang, 1983 with slightly concave tabulae). The postulated identity (Poty \& Boland 1996: 205) of the early Hastarian warm and shallow water coral Conilophyllum tregaense (Poty, 1982) with Hebukophyllum priscum (Münster, 1840) from the cold water cephalopod facies is a case of rather perfect homoeomorphy, but with differences in early skeletal ontogeny and in adult wall structure (very strong longitudi- nal archaeothecal ribs, always seen in rich Conilophyllum tregaense collections from the German basal Tournaisian of Lintorf north of Ratingen, Rhenish Mountains, and of the Baltic Sea island of Rügen).

Hebukophyllum priscum is an excellent index fossil of the Central European "Gattendorfia Stufe", found nearly everwhere during the time interval from late Siphonodella praesulcata Zone to Siphondella sandbergi Zone. German localities are Schübelhammer and Regnitzlosau in Upper Franconia, Saalfeld and Kahlleite in Thuringia, Oberrödinghausen railway cut, Drewer, Hasselbach and Oese in the Rhenish Mountains. There are also new records from Morocco (Mkarig, Ouidane Chebbi region south-east of Erfoud, Anti-Atlas, Acutimitoceras beds above the Hangenberg Black Shale equivalent, coll. R. T. Becker and Ebbighausen).

\section{Subfamily "Amplexocariniidae Soshkina, 1941" (sensu Różkowska 1969)}

\section{Gorizdronia Różkowska, 1969}

\section{Gorizdronia sp. A}

Fig. 25A-H, Pl. 3: 10

Material: One specimen (MB.K.681; 9CS (7P, 2TS) + 3LS (2P, 1TS) + 2R; coll. U. Lemke ca. 1995) from Oese, upper "Wocklumeria Stufe".

Description: The archaeotheca of the straight conical corallum (L $14.5 \mathrm{~mm}$, upper D $8.5 \mathrm{~mm}$, lower D $2.5 \mathrm{~mm}$ ) bears fine rugae and extremely weak, nearly invisible longitudinal septal furrows. The septal apparatus (with maximal 38 major and minor septa) allows a correct orientation only by looking for septal insertions points and by using the biform antiseptal tabulae (Fig. 25B). The cardinal septum (without fossula) is always as long as other major septa, which demonstrate a clear radial position. A peculiar feature, normally unknown in species of Gorizdronia, is the sometimes shortened antiseptum

Fig. 24. Hebukophyllum priscum (Münster, 1840). MB.K.676; Oese quarry, Paprothites dorsoplanus Zone, bed 22; serial sections $21-18,16,14-13,11,8,4-1, \times 9(\mathrm{~A}-\mathrm{B}), \times 8(\mathrm{C}-\mathrm{E}, \mathrm{G}-\mathrm{J}), \times 6(\mathrm{~F}, \mathrm{~K})$, and $\times 7$ (L-M); calicular parts only in the centre of L-M. (see P1. 4: 5-8).

\begin{tabular}{lc|c} 
Septal formulae & 3 & $\mathbf{3}$ \\
\cline { 2 - 2 } MB.K.676 & 3 & 3 \\
$\mathrm{n}$ & 17 \\
$\mathrm{~N}$ & 24 \\
$\mathrm{D}(\mathrm{mm})$ & $3.2 \times 3.8$ \\
Fig. & A
\end{tabular}

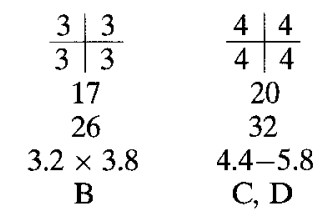

\begin{tabular}{c|c}
5 & 5 \\
\hline $4 \mid 6$ \\
23 \\
38 \\
5.4 \\
$G$
\end{tabular}

\begin{tabular}{c|c}
5 & 4 \\
\hline 4 & 4 \\
21 \\
34 \\
5.6 \\
$\mathrm{H}$
\end{tabular}

\begin{tabular}{c|c}
4 & 4 \\
\hline 4 & 4 \\
21 \\
34 \\
6.2 \\
I
\end{tabular}

$$
\begin{array}{c|c}
4 & 4 \\
\hline 4 & 4 \\
20 \\
32 \\
5.4-7.5 \\
\text { I, L, M }
\end{array}
$$



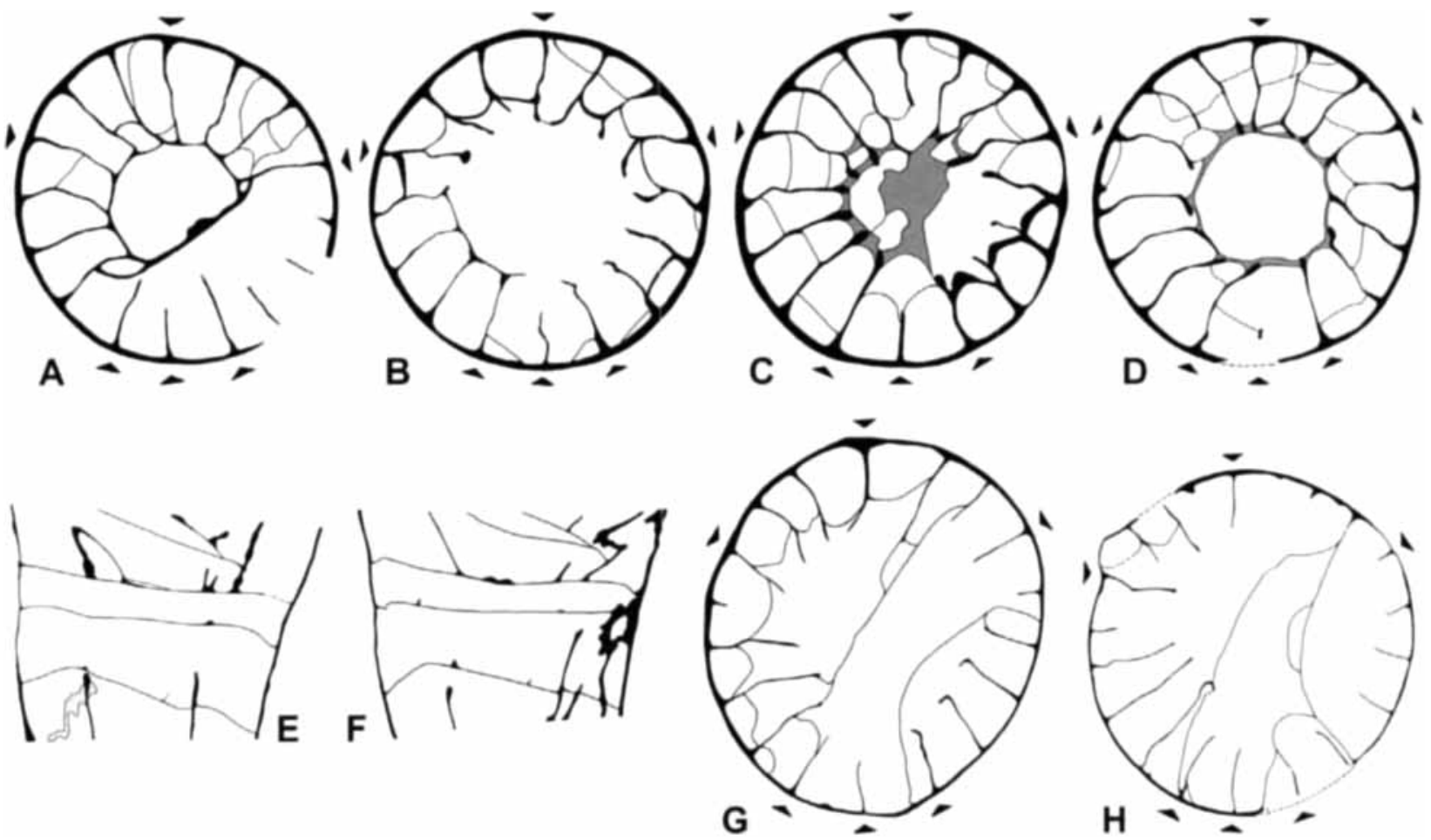

Fig. 25. Gorizdronia sp. A. MB.K.681: Oese. upper "Wocklumeria Stufe"; subtabular serial sections $11-6,4,2, \times 8.5$ (A-C), $\times 8$ (D), $\times 5.5(\mathrm{E}, \mathrm{F}), \times 6(\mathrm{G})$, and $\times 5(\mathrm{H})$. (see Pl. 3: 10).

\begin{tabular}{|c|c|c|c|}
\hline Septal formulae & 33 & $3 \mid 3$ & 34 \\
\hline МВ.К. 681 & \begin{tabular}{l|l}
5 & 5
\end{tabular} & \begin{tabular}{l|l}
6 & 5
\end{tabular} & $6: 6$ \\
\hline $\mathrm{n}$ & 20 & 21 & 23 \\
\hline $\mathrm{N}$ & 32 & 33 & 38 \\
\hline $\mathrm{D}(\mathrm{mm})$ & $4.6-4.7$ & 4.9 & $6.8-8.3$ \\
\hline Fig. & $A-C$ & D & $\mathrm{G}, \mathrm{H}$ \\
\hline
\end{tabular}

(Fig. 25A-D, G). Immediately above a tabula, an aulos may be developed completely or partially throughout short vertical phases, but the common structure are brevisepta. Very tiny minor septa become visible in some places of the terminal stages (Fig. 25G, H). Simple tabulae vary from horizontal to slightly arched, with a very small region of bending down at the archaeothecal contact.

Discussion: An interpretation of such breviseptal taxa causes many problems, especially in discriminating real and suitable species criteria, what will be possible only by investigation of larger populations. The best studied material from the upper Famennian of the Holy Cross Moun- tains are Gorizdronia soshkinae Róžkowska, 1974, Gorizdronia ténuis Róžkowska, 1969, and Gorizdronia geniculata Róžkowska, 1969; they all differ in the missing aulate phases. This is also true for a late Famennian "Gorizdronia soshkinae" illustrated by Berkowski (2002: pl. 14, figs 6-8). The holotype of Gorizdronia soshkinae, designated by Różkowska (1974: Nalivkinella profunda Soshkina 1951, pl. 1, fig. 2a-b, non Soshkina 1939) comes from an unknown stratigraphic position within the Famennian, and is not necessarily conspecific with the Polish records. There exist several undescribed Gorizdronia specimens in the Weyer collection (upper Famennian of Thuringia). All these corals never show a shortened antiseptum.

Fig. 26. Drewerelasma schindewolfi Weyer, 1973. MB.K.675; Hasselbach N, Paragattendorfia patens Zone, bed 41; serial sections $29-27,23,19-17,15,13,11-10,8-3,1, \times 40(\mathrm{~A}-\mathrm{C}), \times 25(\mathrm{D}), \times 14(\mathrm{E}), \times 12(\mathrm{~F}-\mathrm{H}), \times 10(\mathrm{I}), \times 8.5(\mathrm{~J}-\mathrm{K}), \times 7.5(\mathrm{~L})$, $\times 6.5(\mathrm{M}-\mathrm{N}), \times 6(\mathrm{O}-\mathrm{P})$, and $\times 5.5(\mathrm{Q}-\mathrm{R})$; calicular base around $\mathrm{H}-\mathrm{K}$; metriophylloid carinae in $\mathrm{B}$ (stippled), E (antiseptum), I (tangential LS). J. L. M. (see Pl. 4: 12-14).

\begin{tabular}{|c|c|c|c|c|c|}
\hline Septal formulae & $\begin{array}{l:l}1 & 1 \\
\end{array}$ & $1: 2$ & $2: 2$ & & \\
\hline МВ.К. 675 & $2: 2$ & $\begin{array}{l:l}3 & 2\end{array}$ & 44 & \begin{tabular}{l|l}
4 & 4 \\
\end{tabular} & 55 \\
\hline $\mathrm{n}$ & 10 & 12 & 16 & 18 & 24 \\
\hline $\mathrm{N}$ & $12-15$ & 17 & 24 & 28 & 40 \\
\hline $\mathrm{D}(\mathrm{mm})$ & $1.4-2.3$ & 2.5 & 2.8 & 3.0 & $4.5-7.4$ \\
\hline Fig. & $D-E$ & F & G & $\mathrm{H}$ & $\mathbf{J}-\mathbf{R}$ \\
\hline
\end{tabular}



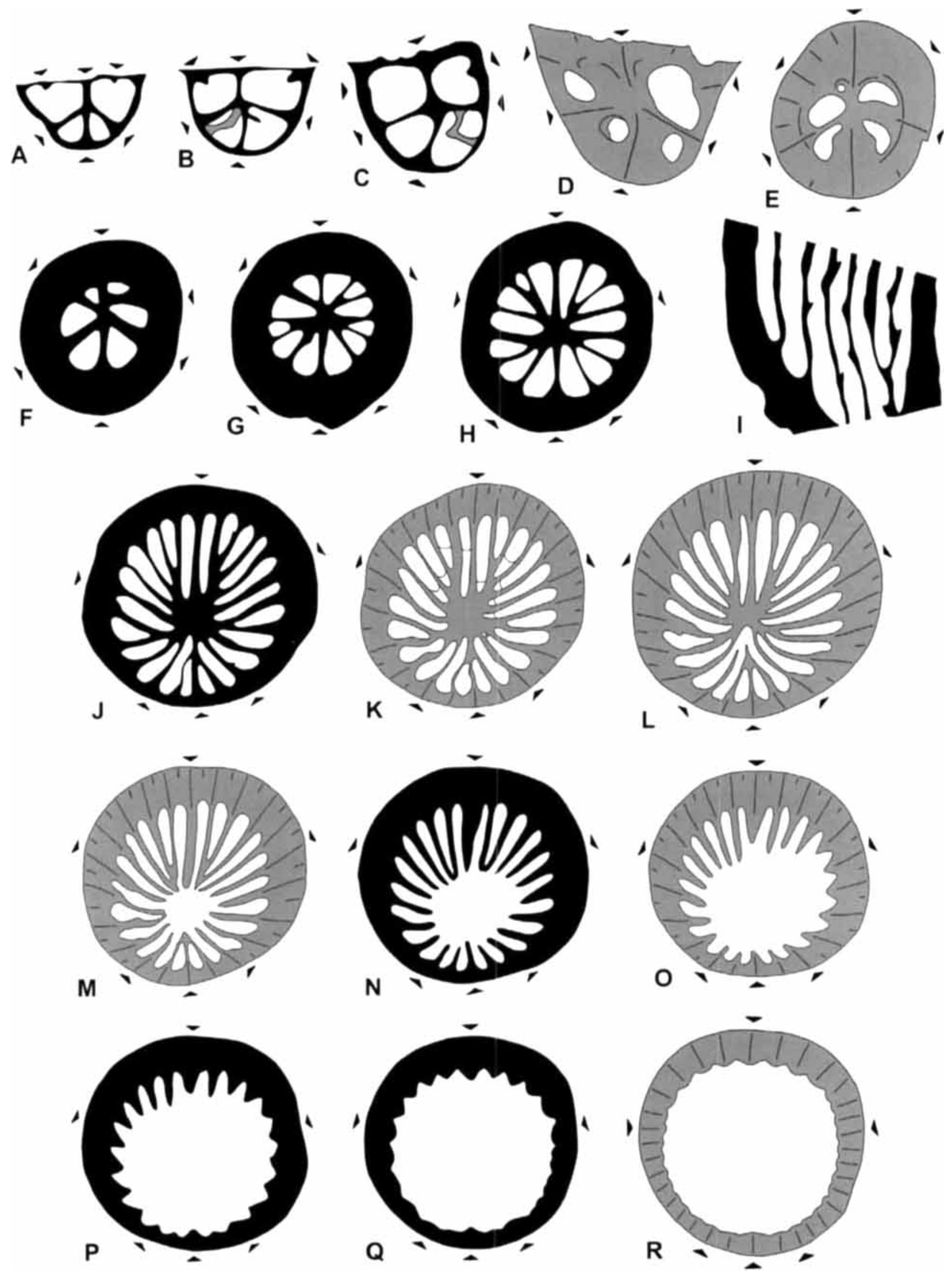

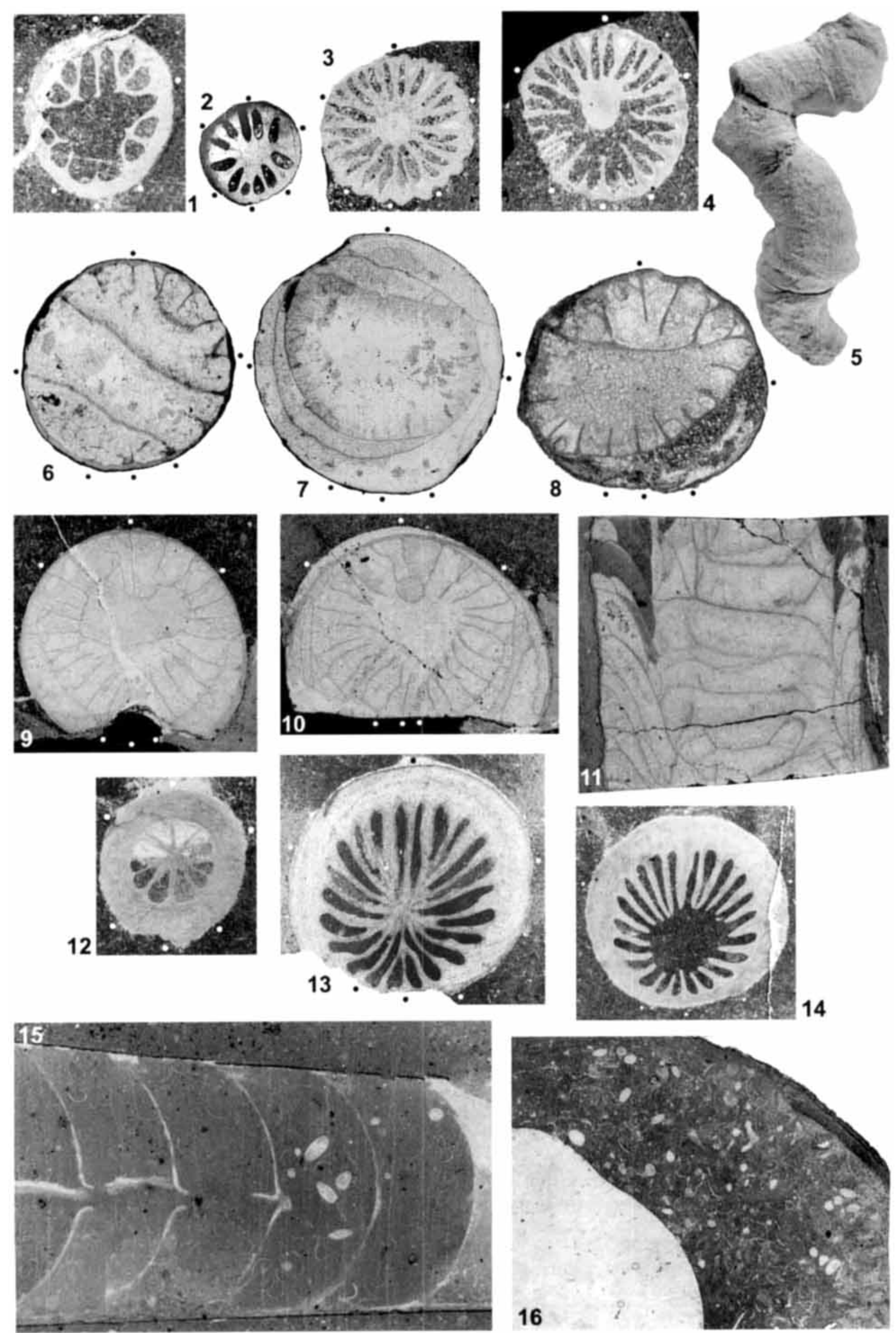
Suborder Zaphrentoidina Schouppé \& Stacul, 1959

Family Lindstroemiidae Počta, 1902

Drewerelasma Weyer, 1973

Drewerelasma schindewolfi Weyer, 1973

Fig. 26A-R, Pl. 4: 12-14

* 1973c Drewerelasma schindewolfi n. sp. - Weyer: 978, figs $1-7$.

1994 Drewerelasma schindewolfi Weyer, 1973 - Weyer: 196, figs $7 / 1-16,8 / 1-11,9 / 1-5$, pl. 4: figs 3-4, pl. 5: figs $1-3$.

Material: One specimen (MB.K.675; 27 CS (25P, 2TS) +3LS (P) + 3R; coll. Weyer 1994) from Hasselbach N (bed 41); lower Tournaisian ("Gattendorfia Stufe"), Paragattendorfia patens Zone (Siphonodella sandbergi Zone).

Description: The conical cornute, excellently preserved and complete corallum ( $\mathrm{L}$ ca. $17 \mathrm{~mm}$, upper D $10.5 \mathrm{~mm}$, lower D $0.5 \mathrm{~mm}$ ) is imbedded in the limestone matrix. From serial sectioning it became evident, that there are only fine growth rugae on the external archaeotheca. The intensive series of cross sections includes the mature deep calice and a complete ontogeny starting with seeming 6 protosepta (Fig. 26A), in reality 10 septa, 4 of them hidden in the later on thickened wall. Within the calice, the cardinal septum at the convex side is generally as long as all neighbouring major septa, and especially thickened in Fig. 26M-N, with a first trend to a minimal length reduction (Fig. 26O-P). An antiseptal triade with two longer contratingent minor septa occurs in middle and late phases, but is absent in the youth (Fig. 26A-H) where its place is indicated by comparatively large interseptal chambers at both sides of the antiseptum. Other minor septa are only active as short protuberances, indistinguishable from major septa, in the uppermost calice (Fig. 26R). Deeper in the middle calice, they become incorporated into the continuously thickening wall. Metriophylloid carinae can be seen several times, even in the earliest growth stages (Fig. 26B).

Discussion: The new record is very near to the hypotype from Drewer in the Rhenish Mountains, as figured by Weyer (1994: fig. 7). Apparent differences in septal thickening seem to fall into the normal intraspecific variation; at least at the moment it would be premature to propose a new taxon. There are rather few descriptions for representatives of the genus, in spite of its wide distribution in the lower Tournaisian from southern France (Montagne Noire, stratotype La Serre section, coll. Weyer 1995) across Central Europe and the Ural Mountains (Berchogur section, "Imitoceras bed" of Siphonodella sulcata Zone, Alekseev et al. 1987) to northwestern China (Xinjiang, Hoboksar section, described by Liao \& Cai 1987 as Metriophyllum). Rich collections from Saalfeld (Thuringian Mountains) offer an enormous variability; their preliminary determination was Drewerelasma sp. aff. curviseptatum (Liao \& Cai, 1987) (Weyer 2001: fig. 3/2).

\section{Acknowledgements}

We are indebted to Eva Paproth (Krefeld), R. Thomas Becker (Münster), and Ulrich Lemke (Wetter) for providing ammonoid and coral specimens for study. Many thanks to Evelyn Stenzel (Berlin) and Frank Trostheide (Magdeburg) for the skilfull preparatory work, and to Wolfgang Gerber (Tübingen) for the photography of the ammonoid specimens. Information about chemical analyses of metabentonites were kindly made available by Knut Hahne (Potsdam). Many thanks also to Dieter Stoppel (Hannover) for making the Hasselbach drilling core available for study, to Jürgen Kullmann (Tübingen, for reviewing the manuscript) and David Unwin (Berlin) for revising the style. Finally, many thanks to Helga Groos-Uffenorde (Göttingen) and Ludmilla Kononova (Moscow) for the loan and investigation of the important conodont specimen Siphonodella sulcata from Hasselbach.

Plate 4. Corals from the lower Tournaisian ("Gattendorfia Stufe"). 1. Bathybalva crassa Weyer, 1981; MB.K.671; Hasselbach N, Acutimitoceras acutum Zone, bed 76; calicular cross section 7, $\times 10$. (see Fig. 17A-J). 2. Cyathaxonia sp. B; MB.K.674; Hasselbach N, Paprothites dorsoplanus Zone, bed 65; calicular cross section 3, $\times 12$. (see Fig. 16H-L). 3-4. Cyathaxonia sp. B; MB.K.673; Hasselbach N, Acutimitoceras acutum Zone, bed 81; calicular cross sections 7, 4, $\times 10$. (see Fig. 16A-G). 5-8. Hebukophyllum priscum (Münster, 1840); MB.K.676; Oese quarry, Paprothites dorsoplanus Zone. (see Fig. 24A-M). 5. side view of corallum (lower two thirds), $\times 2.5 .6-8$. subtabular serial cross sections $18,16,5, \times 7(6,7)$ and $\times 8(8)$. 9-11. Hebukophyllum priscum (Münster, 1840); MB.K.638; Hasselbach N, Acutimitoceras prorsum Zone; subtabular cross sections 7, 8, and longitudinal section 9, $\times$ 4. (see Fig. 23A-G). 12-14. Drewerelasma schindewolfi Weyer, 1973; MB.K.675; Hasselbach N. Paragattendorfia patens Zone; cross sections 17, 9, 6, ×4. (see Fig. 26A-R). 15. Psychrosphaeric ostracode carapaces (Thuringian ecotype) in the phragmocone of an indeterminable orthocone nautiloid; Hasselbach N, "Gattendorfia Stufe" (bed 51, Late Siphonodella duplicata Zone, base of Pseudarietites westfalicus Zone; coll. Weyer 1994, thin section, $\times 10$. 16. Psychrosphaeric ostracode carapaces (Thuringian ecotype), mass occurrence in the body chamber of an Acutimitoceras kleinerae Korn, 1984; MB.C.5269, Oese quarry, "Gattendorfia Stufe", lower part of the Hangenberg Limestone; coll. Weyer 1993, cross section peel, $\times 10$. 


\section{References}

Afanas'eva, G. A. 2002. Brakhiopody otryada Chonetida iz basseynovykh fatsii pogranichnykh otlozheniy devona i karbona Tyuringskikh i Reynskikh Slantsevykh Gor (Germaniya). [Brachiopods of the Order Chonetida fram the Basin Facies of the Devonian-Carboniferous Transitional Strata of the Thuringian and Rhenish Slate Mountains (Germany)]. - Paleontologicheskiy Zhurnal 2002 (6): 57-62 [English translation: 626-631].

Alekseev, A. S., Barskov, I. S. \& Kononova, L. I. 1987. Razrez Berchogur. [Berchogur section]. In Maslov, V. A. (ed.): Fauna i biostratigrafiya pogranichnykh otlozheniy devona i karbona Berchogura (Mugodzhary). [Fauna and biostratigraphy of the Devonian-Carboniferous boundary beds of Berchogur (Mugodzhary)]. - Institut Geologii. Bashkirskiy Filial, Akademiya Nauk SSSR: 1-120 (38-48): Moskva.

Bartzsch, K., Blumenstengel, H. \& Weyer. D. 1993. Field Excursion Saalfeld 31 July-3 August 1993 to the Palaeozoic (Devonian) of Thuringia. Guidebook. - Göttingen Meeting 31 July-6 August 1993 (Gross symposium), Subcommission on Devonian Stratigraphy SDS (International Union of Geological Sciences). IGCP Project 328 Palaeozoic Microvertebrates; $1-60$; Göttingen.

- 1999. Stratigraphie des Oberdevons im Thüringischen Schiefergebirge. Teil 1: Schwarzburg-Antiklinorium. Beiträge zur Geologie von Thüringen. Neue Folge 6: 159-189.

- 2002. Stratigraphie des Oberdevons im Thüringischen Schiefergebirge. Teil 2: Berga-Antiklinorium. - Beiträge zur Geologie von Thüringen, Neue Folge 8: 303-327.

Bartzsch. K., Hahne, K. \& Weyer, D. 1998. Der HangenbergEvent (Devon/Karbon-Grenze) im Bohlen-Profil von Saalfeld (Thüringisches Schiefergebirge). - Abhandlungen und Berichte für Naturkunde (Museum für Naturkunde Magdeburg) 20:37-58.

Bartzsch, K. \& Weyer, D. 1982: Zur Stratigraphie des Untertournai (Gattendorfia-Stufe) von Saalfeld im Thüringischen Schiefergebirge. - Abhandlungen und Berichte für Naturkunde und Vorgeschichte (Kulturhistorisches $\mathrm{Mu}$ seum Magdeburg), [for 1981] 12 (4): 3-53.

- 1987. Die unterkarbonische Ammonoidea-Tribus Pseudarietini. - Abhandlungen und Berichte für Naturkunde und Vorgeschichte (Kulturhistorisches Museum Magdeburg) 13: $59-68$.

- 1988. Die unterkarbonische Ammonoidea-Subfamilia Karagandoceratinae. - Freiberger Forschungs-Hefte C 419: $130-142$.

- 1996. Voehringerites Manger 1971 (Ammonoidea) im Untertournai des Thüringischen Schiefergebirges. - Abhandlungen und Berichte für Naturkunde (Museum für Naturkunde Magdeburg) 19: 73-81.

Becker, G. 1999. Verkieselte Ostracoden vom Thüringer Ökotyp aus den Devon/Karbon-Grenzschichten (Top Wocklumer Kalk und Basis Hangenberg-Kalk) im Steinbruch Drewer (Rheinisches Schiefergebirge). Die "natürliche" D/C-Grenze. - Courier Forschungsinstitut Senckenberg 218: $1-159$

Becker, G., Clausen, C.-D. \& Leuteritz. K. 1993. Verkieselte Ostracoden vom Thüringer Ökotyp aus dem Grenzbereich Devon/Karbon des Steinbruchs Drewer (Sauerland. Rheinisches Schiefergebirge). - Courier Forschungsinstitut Senckenberg 160: 1-131.

Becker, R. T. 1985. Devonische Ammonoideen aus dem Raum Hohenlimburg-Letmathe (Geologisches Blatt 4611 Hohenlimburg). - Dortmunder Beiträge zur Landeskunde. naturwissenschaftliche Mitteilungen 19: 19-34.

- 1988. Ammonoids from the Devonian-Carboniferous Boundary in the Hasselbach Valley (Northern Rhenish Slate Mountains). - Courier Forschungsinstitut Senckenberg 100: 193-213.
- 1996. New faunal records and holostratigraphic correlation of the Hasselbachtal D/C-Boundary Auxilliary Stratotype (Germany). - Annales de la Société géologique de Belgique 117 (1): 19-45.

Becker, R. T.. Bless, M. J. M., Brauckmann, C., Friman, L., Higgs, K., Keupp, H., Korn, D., Langer, W., Paproth, E., Racheboeuf, P., Stoppel, D., Streel, M. \& Żakowa, H. 1984. Hasselbachtal, the section best displaying the Devonian-Carboniferous Boundary beds in the Rhenish Massif (Rheinisches Schiefergebirge). - Courier Forschungsinstitut Senckenberg 67: 181-191.

Becker, R. T., House, M. R., Bockwinkel, J., Ebbighausen, V. \& Aboussalam, Z. S. 2002. Famennian ammonoid zones of the eastern Anti-Atlas (southern Morocco). - Münstersche Forschungen zur Geologie und Paläontologie 93: 159-205.

Becker. R. T., Korn. D., Paproth, E. \& Streel, M. 1993. Beds near the Devonian-Carboniferous boundary in the Rhenish Massif. Germany. - Subcommission on Carboniferous Stratigraphy (SCCS), International Union of Geological Sciences, Commission on Stratigraphy, 10-12 June, 1993. Guidebook: 1-86; Services associés de paléontologie, Université, Liège.

Becker. R. T. \& Paproth. E. 1993. Auxilliary stratotype sections for the global stratotype section and point (GSSP) for the Devonian-Carboniferous boundary. - Annales de la Société géologique de Belgique 115 (2) (for 1992): $703-706$.

Berkowski, B. 2002: Famennian Rugosa and Heterocorallia from southern Poland. - Palaeontologia Polonica 61: $1-87$.

Bless. M. J. M. 1983. Late Devonian and Carboniferous ostracode assemblages and their relationship to the depositional environment. - Annales de la Société Géologique de Belgique 92 (1): 31-53.

Bless, M. J. M. \& Groos-Uffenorde, H. 1984. Ostracodes at the Devonian-Carboniferous Boundary boundary. - Courier Forschungsinstitut Senckenberg 67: 23-28.

Boland, K. 1997. Caninoid Rugose Corals of the Lower Tournaisian (Hastarian) of Belgium: systematics and evolution. - Boletín de la Real Sociedad Española de Historia Natural. Sección Geológica 91 (1-4) (Perejón, A. \& Comas-Rengifo, M. J., eds: Proceedings of the VII International Symposium on Fossil Cnidaria and Porifera held in Madrid, Spain, 1995): 73-84.

Branson. E. B. \& Mehl, M. G. 1934. Conodont studies no. 4; Conodonts from the Bushberg sandstone and equivalent formations of Missouri. - Missouri University Studies 8 (4): $265-300$

Brauckmann, C. \& Hahn, G. 1984. Trilobites as index fossils at the Devonian-Carboniferous Boundary. - Courier Forschungsinstitut Senckenberg 67: 11-14.

Brauckmann, C., Chlupáć. I. \& Feist, R. 1993. Trilobites at the Devonian-Carboniferous Boundary. - Annales de la Societé Géologique de Belgique 115 (2) (for 1992): 507-518.

Byvsheva, T. V, Higgs, K. \& Streel, M. 1984. Spore correlations between the Rhenish Slate Mountains and the Russian Platform near the Devonian-Carboniferous Boundary. - Courier Forschungsinstitut Senckenberg 67: $37-45$.

Claoué-Long, J. C., Compston, W., Roberts, J. \& Fanning, C. M. 1995. Two Carboniferous ages: a comparison of SHRIMP zircon dating with conventional zircon ages and ${ }^{+0} \mathrm{Ar}{ }^{30} \mathrm{Ar}$ analysis. In Berggren, W. A., Kent, D. V., Aubry, M. P. \& Hardenbol, J. (eds): Geochronology. Time Scales and Global Stratigraphic Correlation. - SEPM [Society for Sedimentary Geology] Special Publication 54: $1-27$.

Claoué-Long, J. C., Jones, P. J. \& Roberts, J. 1993. The age of the Devonian-Carboniferous boundary. - Annales de la Société Géologique de Belgique 115 (2) (for 1992): $531-549$. 
Claoué-Long, J. C., Jones, P. J., Roberts, J. \& Maxwell, S (1992): The numerical age of the Devonian-Carboniferous boundary. - Geological Magazine 129 (3): 281-291.

Clausen, C. D., Korn, D., Leuteritz, K., Paproth, E. \& Stoppel, D. 1987. Die Devon-Karbon-Grenze im nördlichen und nordöstlichen Sauerland. - Subkommission für Karbonstratigraphie in der D. U. G. W., Exkursionsführer [Tagung] Olsberg 25.9.-27. 9. 1987: 1-35; Krefeld.

Clausen, C.-D., Leuteritz, K. \& Ziegler, W. 1987. The eastern Provincial Quarry at Drewer (northeastern Rhenish Slate Mountains), a stratotype candidate for the Devonian/Carboniferous Boundary. - Senckenbergiana lethaea $87(5 / 6)$ : $467-477$.

- 1989, with a contribution by Korn, D. Ausgewählte Profile an der Devon/Karbon-Grenze im Sauerland (Rheinisches Schiefergebirge). - Fortschritte in der Geologie von Rheinland und Westfalen 35: 161-226.

Compston, W. 2000. Inmterpretation of SHRIMP and isotope dilution zircon ages fort he Palaeozoic time-scale: II. Silurian to Devonian. - The Mineralogical Magazine 64 (6): $1127-1146$.

Denckmann, A. 1901. Ueber das Oberdevon auf Blatt Balve (Sauerland). - Jahrbuch der Königlich Preussischen geologischen Landesanstalt und Bergakademie 21 (for 1900): I-XIX.

Džik, J. 1997. Emergence and succession of Carboniferous conodont and ammonoid communities in the Polish part of the Variscan sea. - Acta Palaeontologica Polonica 42 (1): $57-170$.

Fedorowski, J. 1991. Dividocorallia, a new subclass of Palaeozoic Anthozoa. - Bulletin de l'Institut Royal des Sciences Naturelles de Belgique, sciences de la terre 61: 21-105.

Feist, R., Lemke, U. \& Korn, D. 2000. Trilobiten aus der Wocklumeria-Stufe des höchsten Oberdevon von Apricke, Sauerland. - Senckenbergiana lethaea 79 (2): 517-539.

Flajs, G. \& Feist, R. 1988. Index conodonts, trilobites and environment of the Devonian-Carboniferous Boundary beds at La Serre (Montagne Noire, France). - Courier Forschungsinstitut Senckenberg 100: 53-107.

Gandl, J. 1968. Die Schichtenfolge im Unterkarbon des Frankenwaldes; Fundorte und Fundschichten der Trilobiten. Senckenbergiana lethaea 49 (5/6): 489-546.

Groos-Uffenorde, H. \& Uffenorde, H. 1974. Zur Mikrofauna im höchsten Oberdevon und tiefen Unterkarbon im nördlichen Sauerland (Conodonta, Ostracoda, Rheinisches Schiefergebirge). - Notizblatt des hessischen Landesamtes für Bodenforschung 101: 58-87.

Grubbs, D. M. 1939. Fauna of the Niagaran nodules of the Chicago area. - Journal of Paleontology 13 (6): 543-560.

Gründel, J. 1961. Zur Biostratigraphie und Fazies der Gattendorfia-Stufe in Mitteldeutschland unter besonderer Berücksichtigung der Ostracoden. - Freiberger Forschungshefte C 111: 53-173.

Higgs, K. \& Streel, M. 1984. Spore stratigraphy at the Devonian-Carboniferous Boundary in the northern "Rheinisches Schiefergebirge", Germany. - Courier Forschungsinstitut Senckenberg 67: 157-179.

Higgs, K. T., Streel, M., Korn, D. \& Paproth, E. 1993. Palynological data from the Devonian-Carboniferous Boundary beds in the new Stockum trench 2 and the Hasselbach borehole, northern Rhenish Massif. - Annales de la Société Géologique de Belgique 115 (for 1992): 551-557.

Huddle, J. W. 1934. Conodonts from the New Albany Shale of Indiana. - Bulletins of American Paleontology 72: $1-113$.

Hyatt, A. 1883-1884. Genera of fossil cephalopods. - Proceedings of the Boston Society of Natural History 22: 253-338 (253-272 publ. 1883, 273-338 publ. 1884)

Ji Qiang 1985. Study on the Phylogeny, Taxonomy, Zonation and Biofacies of Siphonodella (Conodonta). - Bulletin of the Institute of Geology, Chinese Academy of Geological Sciences 11: $51-75$.
Ji Qiang \& Ziegler, W. 1992. Phylogeny, speciation and zonation of Siphonodella of shallow water facies (Conodonta, Early Carboniferous) - Courier Forschungsinstitut Senckenberg 154: 223-251.

Jongmans, W. J. \& Gothan. W. 1937. Betrachtungen über die Ergebnisse des zweiten Kongresses für Karbonstratigraphie. - Compte rendue, 2ème Congrès pour l'avancement des études de Stratigraphie Carbonifère Heerlen, Septembre 1935, tome 1: $1-40$.

Keupp, H. \& Kompa, R. 1984. Mikrofazielle und sedimentologische Untersuchungen an Devon/Karbon-Profilen am Nordrand des Rechtsrheinischen Schiefergebirges. - Courier Forschungsinstitut Senckenberg 67: 139-142.

Klapper, G. 1966. Upper Devonian and Lower Mississippian conodont zones in Montana, Wyoming, and South Dakota. - University of Kansas Paleontological Contributions, Paper 3: $1-43$.

Koninck, L. G. de 1872. Nouvelles Recherches sur les Animaux Fossiles du Terrain Carbonifère de la Belgique. Première Partie. - Mémoires de l'Académie Royale des Sciences, des Lettres et des Beaux-Arts de Belgique 39: I-IV, $1-178$.

Korn, D. 1979. Mediandornen bei Kosmoclymenia Schindewolf (Ammonoidea, Cephalopoda). - Neues Jahrbuch für Geologie und Paläontologie, Monatshefte 1979 (7): $399-405$.

- 1981. Ein neues, Ammonoideen-führendes Profil an der Devon-Karbon-Grenze im Sauerland (Rhein. Schiefergebirge). - Neues Jahrbuch für Geologie und Paläontologie, Monatshefte 1981 (9): 513-526.

- 1984. Die Goniatiten der Stockumer Imitoceras-Kalklinsen (Ammonoidea; Devon/Karbon-Grenze). - Courier Forschungsinstitut Senckenberg 67: 71-89.

- 1991. Threedimensionally preserved clymeniids from the Hangenberg Black Shale of Drewer (Cephalopoda, Ammonoidea; Devonian/Carboniferous boundary; Rhenish Massif). - Neues Jahrbuch für Geologie und Paläontologie, Monatshefte 1991 (9): 553-563.

- 1993. The ammonoid faunal change near the DevonianCarboniferous Boundary. - Annales de la Société Géologique de Belgique 115 (for 1992): 581-593.

- 1994. Oberdevonische und unterkarbonische Prionoceraten aus dem Rheinischen Schiefergebirge. - Geologie und Paläontologie in Westfalen 30: 1-85.

- 1999. Famennian Ammonoid Stratigraphy of the Ma'der and Tafilalt (Eastern Anti-Atlas, Morocco). - Abhandlungen der Geologischen Bundesanstalt 54: 147-179.

- 2000. Morphospace occupation of ammonoids over the Devonian-Carboniferous boundary. - Paläontologische Zeitschrift 74 (3): 247-257.

- 2001. Faziesbereiche im Unterkarbon am Nordrand des Rheinischen Schiefergebirges. Exkursionsführer, Tagung der Subkommission für Karbon-Stratigraphie in der DUGW, Warstein 26.-28. April 2001. - Institut und Museum für Geologie und Paläontologie, Eberhard Karls Universität Tübingen: $1-26$.

Korn, D., Clausen, C.-D., Belka, Z., Leuteritz, K., Luppold, F. W., Feist, R. \& Weyer, D. 1994. Die Devon/KarbonGrenze bei Drewer (Rheinisches Schiefergebirge). Geologie und Paläontologie in Westfalen 29: 97-147.

Kramm, U., Lork, A. \& Paproth, E. 1991. Datierung der Grenze Devon-Karbon. - Zentralblatt für Geologie und Paläontologie I, 1991 (5): 1336-1338.

Kullmann, J. 1965. Rugose Korallen der Cephalopodenfazies und ihre Verbreitung im Devon des südöstlichen Kantabrischen Gebirges (Nordspanien). - Akademie der Wissenschaften und der Literatur [in Mainz], Abhandlungen der mathematisch-naturwissenschaftliche Klasse 1965 (2): 33-168.

Kürschner, W., Becker, R. T., Buhl, D. \& Veizer, J. 1993. Strontium isotopes in conodonts: Devonian-Carboniferous transition, the northern Rhenish Slate Mountains, Germany. - Annales de la Société Géologique de Belgique 115 (2): 595-621. 
Liao Wei-hua \& Cai Tu-ci 1987. Sequence of Devonian rugose coral assemblages from northern Xinjiang. - Acta Palaeontologica Sinica 26 (6): 689-707.

Liao Wei-hua \& Soto, F. 2001. Hebukophyllum Liao and Cai (Devonian Rugosa) and its related genera. - Acta Palaeontologica Sinica 40 (1): 44-50.

Librovitch, L. S. 1957. O nekotorykh novykh gruppakh goniatitov iz kamennougol'nykh otlozheniy SSSR. - Ezhegodnik Vsesoyuznogo Paleontologicheskogo Obshchestva 16: $246-272$.

Luppold, F. W., Clausen, C.-D., Korn. D. \& Stoppel, D. 1994. Devon/Karbon-Grenzprofile im Bereich von RemscheidAltenaer Sattel, Warsteiner Sattel, Briloner Sattel und Attendorn-Elsper Doppelmulde (Rheinisches Schiefergebirge). - Geologie und Paläontologie in Westfalen 29: 7-69.

Manger, W. L. 1971. The Mississippian ammonoids Karagandoceras and Kazakhstania from Ohio. - Journal of Paleontology 45 (1): 33-39.

Menning. M. \& German Stratigraphic Commission 2002. A geologic time scale 2002. In German Stratigraphic Commission (ed.). Stratigraphic Table of Germany. - Potsdam.

Menning, M., Weyer, D., Drozdzewski. G., Amerom, H. W. J. van \& Wendt. I. 2001. A Carboniferous Time Scale 2000: Discussion and Use of Geological Parameters as Time Indicators from Central and Western Europe. Geologisches Jahrbuch (Hannover) A156: 3-44 (dated 2000).

Michelin, H. 1841-1848. Iconographie Zoophytologique, description par localités et terrains des polypiers fossiles de France et pays environnants. - I-XII. 1-348. atlas: Paris (P. Bertrand) [dated 1840-1847-1841: 1-40, 1842: 42-72, 1843: $73-104,1844:$ 105-144, 1845: 145-184. 1846: 185-248, 1847: 249-328, 1848: 329-348].

Milne-Edwards, H. \& Haime, J. 1850-1855. A Monograph of the British Fossil Corals. - The Palaeontographical Society (London) [Monographs]: I-LXXXV, 1-322. [Part 1, 1850; I-LXXXV, 1-72 (vol. 3-7); Part 2, 1851: 73-146 (vol. 5-12); Part 3, 1852: 147-210 (vol. 6-14): Part 4, 1853: 211-244 (vol. 7-20); Part 5, 1855: 245-322 (vol. 8-29, dated 1854)].

Münster, G. zu 1832. Ueber die Planuliten und Goniatiten im Uebergangs-Kalk des Fichtelgebirges. - 138 pp.. Birner, Bayreuth.

- 1839. Nachtrag zu den Goniatiten des Fichtelgebirges. Beiträge zur Petrefactenkunde 1: 43-55.

- 1840: Die Versteinerungen des Uebergangskalkes mit Clymenien und Orthoceratiten von Oberfranken. - Beiträge zur Petrefacten-Kunde 3: 33-121.

Paeckelmann, W. \& Schindewolf, O. H. 1937. Die DevonKarbon-Grenze. - Compte rendue, 2ème Congrès pour l'avancement des études de Stratigraphie Carbonifère Heerlen, Septembre 1935, tome 2: 703-714.

Paproth, E. \& Streel. M. 1970. Correlations biostratigraphique pres de la limite Devonien/Carbonifère entre les facies littoroux ardennais et les facies bathyaux rhenans. Congrès Colloques Université de Liège 55: 365-398.

Paproth. E. \& Streel, M. [eds] 1982. Devonian-Carboniferous transitional beds of the northern "Rheinisches Schiefergebirge". - Guidebook, IUGS, Comission of the Stratigraphic Working Group on the Devonian/Carboniferous boundary: $1-63$, Liège.

Paproth, E., Becker, R. T., Clausen, C. D., Kompa, R., Korn, D. \& Stoppel, D. 1986. Field trip to the Late Devonian outcrops in the northern Rheinisches Schiefergebirge (Federal Republic of Germany). - Excursion Guide, Field Conference in Aachen 6-14 April 1986 "Late Devonian events around the Old Red Continent": $1-12$; Geologisches Institut, Rheinisch Westfälische Technische Hochschule, Aachen.

Paproth, E., Feist, R. \& Flajs, G. 1991. Decision on the Devonian-Carboniferous Boundary stratotype. - Episodes $14(4): 331-336$
Paul, H. 1954. Die unterkarbonischen Muscheln des Rheinischen Schiefergebirges. - Decheniana 102A: 39-45.

Počta, P. 1902. Anthozoaires et Alcyonaires. In Barrande, J.: Système Silurien du Centre de la Bohême. Partie I. Recherches Paléontologiques. VIII.2.-I-VIII, 1-347, éditée par le Musée Bohême, Prague.

Poty, É. 1982. Deux nouvelles espèces de Tétracoralliaire du sondage de Kastanjelaan-2 à Maastricht, Pays-Bas. - Natuurhistorisch Maandblad (Orgaan van het Natuurhistorisch Genootschap in Limburg. Nederland) 71 (3): 54-58.

Poty, É. \& Boland, K. 1996. Révision des tétracoralliaires caninomorphes de l'Hastarien (Tournaisien) belge. - Annales de la Société Géologique de Belgique, 1994117 (1): 201-225.

Price, J. D. \& House, M. R. 1984. Ammonoids near the Devonian-Carboniferous Boundary. - Courier Forschungsinstitut Senckenberg 67: 15-22.

Richter, R. 1848. Beitrag zur Paläontologie des Thüringer Waldes. Die Grauwacke des Bohlens und des Pfaffenberges bei Saalfeld. I. Fauna. - 1-48, Arnoldi'sche Buchhandlung, Dresden, Leipzig.

Richter, R. \& Richter, E. 1919. Proetiden aus neueren Aufsammlungen im vogtländischen und sudetischen Ober-Devon. - Senckenbergiana 1 (4): 97-130.

- 1951. Der Beginn des Karbons im Wechsel der Trilobiten. - Senckenbergiana 32 (1/4): 219-266.

Róžkowska, M. 1969. Famennian Tetracoralloid and Heterocoralloid fauna from the Holy Cross Mountains (Poland). - Acta Palaeontologica Polonica 14 (1): 1-187.

- 1974. Gorizdronia soshkinae sp. n., a new type species of Gorizdronia Róžkowska, 1969. - Acta Palaeontologica Polonica 19 (4): 531

Ruan Yi-ping 1981. Devonian and earliest Carboniferous ammonoids from Guangxi and Guizhou. - Memoires of Nanjing Institute of Geology and Paleontology, Academia Sinica 15: $1-152$

Sadykov, A. M. 1962. Srednepaleozoyskie dvustvorchatye mollyuski Atasu (Tsentral'nyy Kazakhstan). - Institut Geologicheskikh Nauk, 1-114, Izdatel'stvo Akademii Nauk Kazakhskoy SSR, Alma-Ata.

Sandberg, C. A., Ziegler, W., Leuteritz, K. \& Brill, S. M. 1978. Phylogeny, speciation, and zonation of Siphonodella (Conodonta, Upper Devonian and Lower Carboniferous). - Newsletters on Stratigraphy 7 (2): 102-120.

Schindewolf, O. H. 1920. Neue Beiträge zur Kenntnis der Stratigraphie und Paläontologie des deutschen Oberdevons. - Senckenbergiana 2: 114-129.

- 1923. Beiträge zur Kenntnis des Paläozoikums in Oberfranken, Ostthüringen und dem Sächsischen Vogtlande. I. Stratigraphie und Ammoneenfauna des Oberdevons von Hof a. S. - Neues Jahrbuch für Mineralogie, Geologie und Paläontologie, Beilage-Band 49: 250-357, 393-509.

- 1924. Bemerkungen zur Stratigraphie und Ammoneenfauna des Saalfelder Oberdevons. - Senckenbergiana 6: $95-113$.

- 1937. Zur Stratigraphie und Paläontologie der Wocklumer Schichten (Oberdevon). - Abhandlungen der Preußischen Geologischen Landesanstalt, Neue Folge 178: $1-132$.

- 1951. Über ein neues Vorkommen unterkarbonischer Pericyclus-Schichten im Oberharz. - Neues Jahrbuch für Geologie und Paläontologie, Abhandlungen 93 (1): $23-116$.

- 1952. Über das Oberdevon und Unterkarbon von Saalfeld in Ostthüringen. Eine Nachlese zur Stratigraphie und Ammoneen-Fauna. - Senckenbergiana 32: 281-306.

Schmidt, H. 1924. Zwei Cephalopodenfaunen an der DevonCarbongrenze im Sauerland. - Jahrbuch der Preußischen Geologischen Landesanstalt 44 (for 1923): 98-171.

- 1925. Die carbonischen Goniatiten Deutschlands. - Jahrbuch der Preußischen Geologischen Landesanstalt 45 (for 1924): $489-609$ 
Schouppé, A. \& Stacul, P. 1959. Säulchenlose Pterocorallia aus dem Perm von Indonesisch-Timor (mit Ausnahme der Polycoeliidae). Eine morphogenetische und taxonomische Untersuchung. - Palaeontographica, Supplement-Band 4 [Wanner, J., ed.: Beiträge zur Geologie von Niederländisch-Indien] (5) (4): 197-359.

Sheng Huaibin 1989. Ammonoids. In Ji Qiang et al.: The Dapoushang section. 108-119, Science press, Beijing.

Soshkina, E. D. 1939. Verkhnedevonskie korally Rugosa Urala. [Upper Devonian corals Rugosa of the Ural] . - Trudy Paleontologicheskogo Instituta, Akademiya Nauk SSSR 9 (2): 1-88.

- 1951. Pozdnedevonskie korally Rugosa, ikh sistematika i evolyutsiya. [Late Devonian corals Rugosa, their systematics and evolution]. - Trudy Paleontologicheskogo Instituta, Akademiya Nauk SSSR 34: 1-122.

Soshkina, E. D., Dobrolyubova, T. A. \& Porfir'ev, G. S. 1941. Permskie Rugosa Evropeyskoy chasti SSSR. [The Permian Rugose Corals of the European Part of the USSR] . Paleontologiya SSSR (Paleontologicheskiy Institut, Akademiya Nauk SSSR) $5(3,1):$ 19-304.

Spasskiy, N. Ya. 1977. Devonskie rugozy SSSR (sistematika, stratigraficheskoe i geograficheskoe znachenie). [Devonian Rugosa of the USSR (systematics, stratigraphical and geographical importance]. - Ministerstvo Vysshevo i Srednego Spetsial'nogo Obrazovaniya RSFSR; 1-285, Izdatel'stvo Universiteta, Leningrad.

Steenwinkel, M. van 1984. Sedimentology of the DevonianCarboniferous Boundary sediments in the Oberrödinghausen 1 borehole (Germany). - Courier Forschungsinstitut Senckenberg 67: 123-137.

Termier, H. \& Termier, G. 1948. Le vrai visage de Pseudoclymenia planidorsata Münster. - Compte Rendu Sommaire de la Societé Geologique de France 1948 (1): 116-117.

Tucker, R. D., Bradley, D. C., Ver Straeten, C. A., Harris, A. G., Ebert, J. R. \& McCutcheon, S. R. 1998. New U-Pb zircon ages and the duration and division of Devonian time. - Earth and Planetary Science Letters 158: $175-186$.

Voges, A. 1959. Conodonten aus dem Unterkarbon I und II (Gattendorfia- und Pericyclus-Stufe) des Sauerlandes. Paläontologische Zeitschrift 33 (4): 266-314.

- 1960. Die Bedeutung der Conodonten für die Stratigraphie des Unterkarbons I und II (Gattendorfia- und Pericyclus-Stufe) im Sauerland. - Fortschritte in der Geologie von Rheinland und Westfalen 3 (1): 197-228.

Vöhringer, E. 1960. Die Goniatiten der unterkarbonischen Gattendorfia-Stufe im Hönnetal (Sauerland). - Fortschritte in der Geologie von Rheinland und Westfalen 3 (1): $107-196$.

Walliser, O. H. 1962. Die Arten der Gattung Gyroceratites $\mathrm{H}$ v. Meyer 1831 (Ammonoidea, Unter- bis Mitteldevon). Neues Jahrbuch für Geologie und Paläontologie, Monatshefte 1962 (11): $565-576$.

Walliser, O. H. \& Alberti, H. 1979. Discussion. Statement to the problem of the Devonian/Carboniferous boundary. in Paproth, E., ed.: Report of the Dinantian Working Group. - Compte Rendu, 8. Congrès International de Stratigraphie et de Géologie du Carbonifère, Moscow 1975 [Trudy, 8. Mezhdunarodnyy Kongress po Stratigrafii i Geologii Karbona, Moskva 1975] 3: 13-84 (78-79), Izdatel'stvo Nauka, Moskva.

Wedekind, R. 1918. Die Genera der Palaeoammonoidea Goniatiten). Mit Ausschluß der Mimoceratidae, Glyphioceratidae und Prolecanitidae. - Palaeontographica 62 85-184.

Weyer, D. 1965. Triacrinus Münster, 1839 (Crinoidea) aus der Wocklumeria-Stufe des thüringischen Oberdevons. Geologie 14 (8): 969-981

- 1971. Neaxon regulus (Rh. Richter, 1848), ein Leitfossil der mitteleuropäischen Wocklumeria-Stufe (Anthozoa Rugosa; Oberdevon). - Geologie 20 (3): 292-315.
- 1972a. Rozmanaria, ein neues Rhynchonellida-Genus aus dem europäischen Oberfamenne (Brachiopoda, Oberdevon). - Geologie 21 (1): 84-99.

- 1972b. Zur Morphologie der Rugosa (Pterocorallia). Geologie 21 (6): 710-737.

- 1973a. Über Protozaphrentis Yü, 1957 (Anthozoa Rugosa, Mittelordoviz). - Paläontologische Abhandlungen, Abteilung A, Paläozoologie 4 (4): 695-706.

- 1973b. Famennelasma gen. nov. (Anthozoa Rugosa) aus der Cephalopoden-Fazies des mitteleuropäischen Oberdevons. - Paläontologische Abhandlungen, Abteilung A. Paläozoologie 4 (4): 683-688.

- 1973c. Drewerelasma, ein neues Rugosa-Genus aus der Gattendorfia-Stufe (Unterkarbon) des Rheinischen Schiefergebirges. - Zeitschrift für Geologische Wissenschaften 1 (8): $975-980$.

- 1976. Ein neues Ammonoidea-Genus aus dem Untertournai des Thüringischen Schiefergebirges. - Zeitschrift für geologische Wissenschaften 4 (6): 837-857.

- 1977. Ammonoideen aus dem Untertournai von Schleiz (Ostthüringisches Schiefergebirge). - Zeitschrift für geologische Wissenschaften 5 (2): 167-185

- 1978. Neaxon bartzschi, eine neue Rugosa-Art aus der Wocklumeria-Stufe (Oberdevon) des Thüringischen Schiefergebirges. - Zeitschrift für Geologische Wissenschaften 6 (4): $493-500$.

- 1979. Biostratigraphy of the Devonian-Carboniferous boundary in the German Democratic Republic. Compte Rendu, 8. Congrès International de Stratigraphie et de Géologie du Carbonifère Moscou 1975 [Trudy, 8. Mezhdunarodnyy Kongress po Stratigrafii i Geologii Karbona, Moskva 1975] 2: 97-104.

- 1981a. Korallen der Devon/Karbon-Grenze aus hemipelagischer Cephalopoden-Fazies im mitteleuropäischen variszischen Gebirge - Bathybalva n. g., Thuriantha n. g. (Rugosa). - Freiberger Forschungshefte C363: 111-125.

- 1981b. Glatziella Renz 1914 (Ammonoidea, Clymeniida) im Oberdevon von Thüringen. - Hallesches Jahrbuch für Geowissenschaften 6: 1-12.

- 1984a. Korallen im Paläozoikum von Thüringen. - Hallesches Jahrbuch für Geowissenschaften 9: 5-33.

- 1984b. Neaxon cheilos $n$. sp. aus dem Unterfamenne von Schleiz im Thüringer Schiefergebirge (Anthozoa, Rugosa: Oberdevon). - Abhandlungen und Berichte für Naturkunde und Vorgeschichte (Kulturhistorisches Museum Magdeburg) 12 (5) (for 1982): 3-16, 77-83.

- 1991. Pseudopetraia Soshkina 1951 (Anthozoa, Rugosa) aus dem Unterdevon des Thüringischen Schiefergebirges. - Abhandlungen und Berichte für Naturkunde und Vorgeschichte (Kulturhistorisches Museum Magdeburg) 15: 9-24.

- 1994. Korallen im Untertournai-Profil von Drewer (Rheinisches Schiefergebirge). - Geologie und Paläontologie in Westfalen 29: 177-221.

- 1995. Heterocorallia aus Famenne-Cephalopodenkalken im Rheinischen Schiefergebirge und Tafilalt. - Abhandlungen und Berichte für Naturkunde (Museum für Naturkunde Magdeburg) 18: 103-135.

- 2000. Revision der Gattung Czarnockia Różkowska 1969 (Anthozoa, Rugosa; Oberdevon). - Abhandlungen und Berichte für Naturkunde, Museum für Naturkunde Magdeburg 21: 75-107 (dated 1999, issued 16. 3. 2000).

- 2001. Korallen im Unterkarbon Deutschlands. - Abhandlungen und Berichte für Naturkunde (Museum für Naturkunde, Magdeburg) 23: 57-91 (dated 2000).

Winter, J. 1993. Identification of a benthonic ash layer by crystal morphology of its Zircon population (Bed 79, Hasselbachtal, Rheinisches Schiefergebirge). - Annales de la Société Géologique de Belgique 115 (2) (for 1992): 683-687.

Ye Gan \& Wang Zhi-ping 1983. New genus and species of Early Carboniferous tetracorals from Jiangyou, Sichuan 
province. - Earth Science, Journal of Wuhan College of Geology 1983 (4): 85-93, 172-173 (in Chinese with English summary).

Yu Chang-min 1988. Corals. In Yu Chang-min (ed.): Devonian-Carboniferous Boundary in Nanbiancun. Guilin, China - Aspects and Records. - 1-379 (165-195, 357-359), Science Press, Beijing.

Ziegler, W. 1962. Taxionomie und Phylogenie Oberdevonischer Conodonten und ihre stratigraphische Bedeutung. - Abhandlungen des Hessischen Landesamtes für Bodenforschung 38: $1-166$.
- 1969. Eine neue Conodontenfauna aus dem höchsten Oberdevon. - Fortschritte in der Geologie von Rheinland und Westfalen 17: $343-360$.

- 1971. Field Trip Guidebook - Post-Symposium Excursion, Sept. 15-18, 1971 to Rhenish Slate Mountains and Hartz Mountains. - Symposium on Conodont Taxonomy Marburg/Lahn, September 4-18, 1971: 1-47.

Ziegler. W. \& Sandberg, C. A. 1984. Important candidate sections for stratotype of conodont based Devonian-Carboniferous Boundary. - Courier Forschungsinstitut Senckenberg 67: 231-239.

\section{Appendix}

Conch dimensions and ratios of ammonoids from the Gattendorfia Limestone

\begin{tabular}{rcccccccccc}
\hline & $\mathrm{dm}$ & $\mathrm{ww}$ & $\mathrm{wh}$ & $\mathrm{uw}$ & ah & WER & ww/dm & ww/wh & uw/dm & IZR \\
\hline Mimimitoceras & varicosum & (Schindewolf, & 1923): Oese. bed 11 & (Fig. 14A) \\
MB.C.5263 & 18.83 & 13.52 & 9.75 & 0.83 & 3.70 & 1.55 & 0.72 & 1.39 & 0.04 & 0.62 \\
& 15.14 & 11.3 & 8.26 & 0.90 & 3.17 & 1.60 & 0.75 & 1.37 & 0.06 & 0.62 \\
& 11.96 & 9.32 & 5.98 & 1.16 & 2.64 & 1.64 & 0.78 & 1.56 & 0.10 & 0.56 \\
& 9.33 & 6.91 & 4.82 & 1.19 & 2.13 & 1.68 & 0.74 & 1.43 & 0.13 & 0.56 \\
& 7.20 & 5.65 & 3.32 & & & & 0.78 & 1.70 &
\end{tabular}

Mimimitoceras hoennense Korn, 1994: Hasselbach. bed 59 (Pl. 2: 3-4)

$\begin{array}{lllllllllll}\text { MB.C.5241.2 } & 15.04 & 9.24 & 8.48 & 0.32 & 3.26 & 1.63 & 0.61 & 1.09 & 0.02 & 0.62\end{array}$

Globimitoceras globiforme (Vöhringer, 1960): Hasselbach, bed 57 (PI. 1: 11-12)

$\begin{array}{lllllllllll}\text { MB.C.5240.7 } & 11.99 & 11.18 & 6.44 & 0.94 & 2.08 & 1.46 & 0.93 & 1.74 & 0.08 & 0.68\end{array}$

Paragattendorfia n. sp. I; Oese, bed 28 (Pl. 2: 20-21)

10.75

5.18

$1.72 \quad 1.96 \quad 1.46$

0.94

2.08

0.15

0.62

Paragattendorfia n. sp. I; Oese, bed 22

MB.C.5262.2

16.02

13,88

$8.88 \quad 7.14$

$\begin{array}{lll}2.50 & 2.58 & 1.42\end{array}$

0.87

0.90

1.94

1.80

0.16

0.64

Paragattendorfia n. sp. II; Oese, bed 22 (Pl. 2: 24-25)

MB.C.5262.8

8.04

6.56

2.77

3.25

$1.62 \quad 1.57$

0.82

2.37

0.40

0.42

Hasselbachia multisulcata (Vöhringer, 1960): Hasselbach, bed 57 (Fig. 14E)

$\begin{array}{rrrr}\text { MB.C.5240.3 } & 13.80 & 9.24 & 6.13 \\ & 11.38 & 8.40 & 4.27 \\ 9.42 & 7.52 & 3.25 \\ 7.83 & 6.59 & 2.69 \\ 6.43 & 5.60 & 2.11 \\ 5.25 & 4.56 & 1.7 \\ 4.21 & 3.77 & 1.37 \\ 3.37 & 2.85 & 1.01 \\ 2.67 & 2.29 & 0.82 \\ 2.11 & 1.74 & 0.68 \\ 1.66 & 1.45 & 0.62\end{array}$

$\begin{array}{lll}3.39 & 2.41 & 1.47 \\ 3.85 & 1.96 & 1.46 \\ 3.48 & 1.59 & 1.45 \\ 3.03 & 1.40 & 1.48 \\ 2.61 & 1.18 & 1.50 \\ 2.16 & 1.04 & 1.56 \\ 1.82 & 0.84 & 1.56 \\ 1.54 & 0.70 & 1.59 \\ 1.17 & 0.57 & 1.61 \\ 0.80 & 0.45 & 1.61 \\ & 0.37 & 1.66\end{array}$

$\begin{array}{ll}0.25 & 0.61 \\ 0.34 & 0.54 \\ 0.37 & 0.51 \\ 0.39 & 0.48 \\ 0.40 & 0.44 \\ 0.41 & 0.39 \\ 0.43 & 0.39 \\ 0.46 & 0.31 \\ 0.44 & 0.31 \\ 0.38 & 0.34 \\ & 0.41\end{array}$

Hasselbachia gracilis (Vöhringer, 1960); Hasselbach, bed 57 (Pl. 1: 15-16) 


\begin{tabular}{|c|c|c|c|c|c|c|c|c|c|c|}
\hline & $\mathrm{dm}$ & ww & wh & uw & ah & WER & $\mathrm{ww} / \mathrm{dm}$ & ww/wh & $\mathrm{uw} / \mathrm{dm}$ & IZR \\
\hline \multicolumn{11}{|c|}{ Acutimitoceras subbilobatum (Münster, 1839); Oese, lower part of Hangenberg Limestone (Fig. 14D) } \\
\hline \multirow[t]{12}{*}{ MB.C.5292 } & 19.03 & 9.82 & 10.43 & 0.52 & 4.65 & 1.75 & 0.52 & 0.94 & 0.03 & 0.55 \\
\hline & 14.37 & 7.88 & 8.08 & 0.44 & 3.51 & 1.75 & 0.55 & 0.97 & 0.03 & 0.57 \\
\hline & 10.86 & 6.01 & 5.85 & 0.91 & 2.45 & 1.67 & 0.55 & 1.03 & 0.08 & 0.58 \\
\hline & 8.41 & 4.93 & 4.10 & 1.29 & 1.83 & 1.63 & 0.59 & 1.20 & 0.15 & 0.55 \\
\hline & 6.58 & 3.56 & 3.02 & 1.30 & 1.75 & 1.86 & 0.54 & 1.18 & 0.20 & 0.42 \\
\hline & 4.83 & 3.02 & 2.26 & 1.11 & 1.35 & 1.93 & 0.62 & 1.34 & 0.23 & 0.40 \\
\hline & 3.48 & 2.12 & 1.46 & 0.96 & 0.92 & 1.85 & 0.61 & 1.45 & 0.28 & 0.37 \\
\hline & 2.56 & 1.74 & 1.06 & 0.77 & 0.66 & 1.82 & 0.68 & 1.64 & 0.30 & 0.37 \\
\hline & 1.90 & 1.22 & 0.73 & 0.53 & 0.51 & 1.87 & 0.64 & 1.66 & 0.28 & 0.31 \\
\hline & 1.39 & 1.08 & 0.63 & 0.31 & 0.40 & 1.96 & 0.78 & 1.70 & 0.22 & 0.37 \\
\hline & 0.99 & 0.91 & 0.44 & 0.19 & 0.25 & 1.81 & 0.92 & 2.06 & 0.19 & 0.43 \\
\hline & 0.74 & 0.80 & 0.36 & & & & 1.09 & 2.22 & & \\
\hline
\end{tabular}

Acutimitoceras intermedium (Schindewolf, 1923); Hasselbach, bed 77 (Pl. 2: 12-13)

$\begin{array}{llllllllll}\text { MB.C.5248.1 } & 31.13 & 21.05 & 17.66 & 1.31 & 8.80 & 1.94 & 0.68 & 1.19 & 0.04\end{array}$

Acutimitoceras aff intermedium (Schindewolf, 1923); Hasselbach, bed 80 (Fig. 14C)

$\begin{array}{rrrrrrrrrrr}\text { MB.C.5249.3 } & 11.61 & 7.96 & 4.95 & 3.27 & 2.69 & 1.69 & 0.69 & 1.61 & 0.28 & 0.46 \\ & 8.92 & 5.97 & 3.40 & 3.30 & 2.00 & 1.66 & 0.67 & 1.75 & 0.37 & 0.41 \\ & 6.93 & 4.17 & 2.22 & 3.18 & 1.47 & 1.61 & 0.60 & 1.88 & 0.46 & 0.34 \\ & 5.46 & 3.05 & 1.53 & 2.84 & 1.06 & 1.54 & 0.56 & 2.00 & 0.52 & 0.31 \\ & 4.40 & 2.32 & 1.09 & 2.40 & & & 0.53 & 2.12 & 0.54 & \end{array}$

Acutimitoceras cf intermedium (Schindewolf, 1923); Hasselbach, bed 46 (P1. 1: 1-2)

$\begin{array}{lllllllll}\text { MB.C. } 5235.1 & 58.07 & 27.14 & 32.38 & 1.65 & 0.47 & 0.84 & 0.03\end{array}$

Acutimitoceras convexum (Vöhringer, 1960); Hasselbach, bed 59 (Pl. 2: 1-2)

$\begin{array}{llllllllllll}\text { MB.C.5241.1 } & 23.05 & 11.85 & 12.05 & 1.15 & 5.96 & 1.82 & 0.51 & 0.98 & 0.05 & 0.51\end{array}$

Acutimitoceras cf antecedens (Vöhringer, 1960); Hasselbach, bed 77 (Pl. 2: 8-9)

$\begin{array}{lllllllllll}\text { MB.C.5248.2 } & 11.58 & 6.80 & 5.42 & 2.77 & 3.23 & 1.92 & 0.59 & 1.25 & 0.24 & 0.40\end{array}$

Acutimitoceras cf simile (Vöhringer, 1960); Hasselbach, bed 80 (Fig. 14B)

$\begin{array}{rrrrrrrrrrr}\text { MB.C.5249.4 } & 16.06 & 10.54 & 9.33 & 0.13 & 4.68 & 1.99 & 0.66 & 1.13 & 0.01 & 0.50 \\ & 11.38 & 8.17 & 6.60 & 0.28 & 3.32 & 1.99 & 0.72 & 1.24 & 0.02 & 0.50 \\ & 8.06 & 5.96 & 4.50 & 0.48 & 2.23 & 1.91 & 0.74 & 1.32 & 0.06 & 0.51 \\ & 5.83 & 4.46 & 3.08 & 0.48 & 1.56 & 1.86 & 0.76 & 1.45 & 0.08 & 0.50 \\ & 4.28 & 3.25 & 2.27 & 0.42 & 1.28 & 2.03 & 0.76 & 1.43 & 0.10 & 0.44 \\ & 3.00 & 2.35 & 1.57 & 0.31 & 0.85 & 1.95 & 0.78 & 1.49 & 0.10 & 0.46 \\ & 2.15 & 1.64 & 1.11 & 0.33 & 0.63 & 1.99 & 0.77 & 1.48 & 0.15 \\ & 1.52 & 1.33 & 0.70 & 0.32 & 0.37 & 1.75 & 0.87 & 0.44 \\ & 1.15 & 0.95 & 0.49 & 0.26 & 0.33 & 1.96 & 0.83 & 1.92 & 0.21 & 0.48\end{array}$

Nicimitoceras cf trochiforme (Vöhringer, 1960); Hasselbach, bed 45 (Pl. 1: 3-4)

$\begin{array}{llllllllllll}\text { MB.C.5234.1 } & 15.52 & 8.60 & 9.00 & 0.81 & 5.02 & 2.18 & 0.55 & 0.96 & 0.05 & 0.44\end{array}$

Voehringerites peracutus (Vöhringer, 1960); Hasselbach, bed 72 (Fig. 14K)

$\begin{array}{lrrrrrrrrrr}\text { MB.C.5245.1 } & & 9.26 & 20.63 & & & & & & 0.45 & 0.63 \\ & & 5.71 & 9.09 & & & & & & \\ & 8.13 & 3.96 & 3.92 & 1.47 & 2.09 & 1.81 & 0.49 & 1.01 & 0.18 & 0.47 \\ & 6.05 & 3.40 & 2.75 & 1.35 & 1.55 & 1.81 & 0.56 & 1.24 & 0.22 & 0.44 \\ & 4.49 & 2.78 & 1.95 & 1.16 & 1.08 & 1.73 & 0.62 & 1.43 & 0.26 & 0.45 \\ & 3.42 & 2.32 & 1.39 & 0.98 & 0.72 & 1.60 & 0.68 & 1.67 & 0.29 & 0.48 \\ & 2.70 & 1.84 & 1.05 & 0.81 & 0.61 & 1.67 & 0.68 & 1.75 & 0.30 & 0.42 \\ & 2.09 & 1.48 & 0.84 & 0.68 & 0.45 & 1.62 & 0.71 & 1.76 & 0.32 & 0.46 \\ & 1.64 & 1.18 & 0.57 & 0.55 & 0.33 & 1.57 & 0.72 & 2.05 & 0.33 & 0.43 \\ & 1.31 & 1.01 & 0.52 & 0.42 & 0.33 & 1.80 & 0.77 & 1.95 & 0.32 & 0.36 \\ & 0.98 & 0.76 & 0.37 & 0.25 & 0.25 & 1.80 & 0.78 & 2.05 & 0.25 & 0.34\end{array}$

Gattendorfia subinvoluta (Münster, 1832); Hasselbach, bed 71 (Pl. 2: 10-11)

$\begin{array}{llllllllllll}\text { MB.C.5244.1 } & 12.72 & 7.45 & 3.95 & 6.06 & 3.33 & 1.85 & 0.59 & 1.89 & 0.48 & 0.16\end{array}$ 


\begin{tabular}{llllllllll}
\hline $\mathrm{dm}$ & ww & uw & ah & WER & ww/dm & ww/wh & uw/dm & IZR
\end{tabular}

Gattendorfia subinvoluta (Münster, 1832); Hasselbach, bed 76 (Fig. 14G)

$\begin{array}{rlllll}11.87 & 6.43 & 3.89 & 5.16 & 3.04 & 1.81 \\ 8.83 & 4.95 & 2.82 & 3.92 & 2.30 & 1.83 \\ 6.53 & 3.80 & 2.09 & 2.87 & 1.70 & 1.83 \\ 4.83 & 2.76 & 1.57 & 2.10 & 1.27 & 1.84 \\ 3.56 & 2.07 & 1.16 & 1.52 & 0.94 & 1.85 \\ 2.62 & 1.49 & 0.88 & 1.08 & 0.72 & 1.90 \\ 1.90 & 1.18 & 0.66 & 0.68 & 0.52 & 1.88 \\ 1.39 & 0.95 & 0.57 & 0.41 & 0.40 & 1.99\end{array}$

$1.81 \quad 0.54$

1.83

1.83

1.84

1.85

1.90

1.88

1.99
0.56

0.58

0.57

0.58

0.57

0.62

0.68

$\begin{array}{lll}1.65 & 0.43 & 0.22 \\ 1.76 & 0.44 & 0.18 \\ 1.81 & 0.44 & 0.19 \\ 1.76 & 0.44 & 0.19 \\ 1.78 & 0.43 & 0.19 \\ 1.69 & 0.41 & 0.19 \\ 1.79 & 0.36 & 0.22 \\ 1.67 & 0.30 & 0.29\end{array}$

Gattendorfia costata Vöhringer, 1960; Hasselbach, bed 80 (Fig. 14H, I)

$\begin{array}{crrrrrrrr}\text { MB.C.5249.1 } & 12.50 & 8.36 & 3.81 & 5.74 & 2.35 & 1.52 & 0.67 & 2.19 \\ & 10.15 & 6.15 & 2.95 & 5.13 & 2.05 & 1.57 & 0.61 & 2.09 \\ & 8.11 & 4.55 & 2.07 & 4.43 & 1.58 & 1.54 & 0.56 & 2.19 \\ & 6.52 & 3.32 & 1.61 & 3.57 & 1.25 & 1.53 & 0.51 & 2.06 \\ & 5.27 & 2.55 & 1.34 & 2.89 & 1.11 & 1.60 & 0.48 & 1.89 \\ & 4.16 & 2.10 & 1.03 & 2.34 & 0.84 & 1.57 & 0.50 & 2.03 \\ \text { MB.C.5249.2 } & 3.33 & 1.76 & 0.79 & 1.80 & 0.68 & 1.58 & 0.53 & 2.22 \\ & 2.65 & 1.57 & 0.73 & 1.27 & 0.56 & 1.61 & 0.59 & 2.14 \\ & 2.09 & 1.31 & 0.65 & 0.91 & 0.46 & 1.65 & 0.63 & 2.03 \\ & 10.40 & 6.79 & 3.03 & 5.24 & 2.03 & 1.54 & 0.65 & 2.24 \\ & 8.37 & 4.78 & 2.14 & 4.56 & 1.61 & 1.53 & 0.57 & 2.23 \\ & 6.76 & 3.39 & 1.68 & 3.72 & 1.32 & 1.55 & 0.50 & 2.02 \\ & 5.44 & 2.60 & 1.36 & 2.97 & 1.06 & 1.54 & 0.48 & 1.91 \\ & 4.38 & 2.08 & 1.11 & 2.41 & 0.84 & 1.53 & 0.47 & 1.88 \\ & 3.54 & 1.70 & 0.86 & 1.89 & 0.69 & 1.54 & 0.48 & 1.97 \\ & 2.86 & 1.47 & 0.79 & 1.43 & 0.52 & 1.49 & 0.51 & 1.86 \\ & 2.34 & 1.27 & 0.63 & 1.12 & 0.42 & 1.48 & 0.54 & 2.01 \\ & 1.92 & 1.13 & 0.58 & 0.83 & 0.37 & 1.54 & 0.59 & 1.94 \\ & 1.55 & 1.08 & 0.51 & 0.55 & 0.31 & 1.57 & 0.70 & 2.14 \\ & 1.23 & 1.00 & 0.49 & 0.29 & 0.27 & 1.64 & 0.81 & 2.05 \\ & 0.96 & 0.93 & 0.46 & & & & 0.96 & 2.02\end{array}$

$\begin{array}{lll}2.19 & 0.46 & 0.38\end{array}$

$\begin{array}{lll}0.51 & 0.31\end{array}$

$\begin{array}{lll}0.19 & 0.55 & 0.24\end{array}$

$\begin{array}{lll}2.06 & 0.55 & 0.22\end{array}$

$\begin{array}{lll}1.89 & 0.55 & 0.17\end{array}$

$2.03 \quad 0.56 \quad 0.19$

$\begin{array}{lll}0.22 & 0.54 & 0.15\end{array}$

$\begin{array}{lll}2.14 & 0.48 & 0.23\end{array}$

$\begin{array}{ll}0.48 & 0.23 \\ 0.43 & 0.28\end{array}$

$\begin{array}{lll}2.24 & 0.50 & 0.33\end{array}$

$\begin{array}{lll}2.23 & 0.54 & 0.25\end{array}$

$\begin{array}{lll}2.02 & 0.55 & 0.21\end{array}$

$\begin{array}{lll}1.91 & 0.55 & 0.22\end{array}$

$\begin{array}{lll}1.88 & 0.55 & 0.24\end{array}$

$\begin{array}{lll}1.97 & 0.53 & 0.21\end{array}$

$\begin{array}{lll}1.86 & 0.50 & 0.34\end{array}$

$\begin{array}{lll}2.01 & 0.48 & 0.34\end{array}$

$1.94 \quad 0.43 \quad 0.36$

$\begin{array}{lll}2.14 & 0.36 & 0.38\end{array}$

$\begin{array}{lll}2.05 & 0.23 & 0.45\end{array}$

Gattendorfia molaris Vöhringer, 1960; Hasselbach, bed 57 (Pl. 1: 13-14)

$0.48 \quad 1.31$

0.37

Gattendorfia molaris Vöhringer, 1960; Oese, bed 28 (Pl. 2: 18-19)

$\begin{array}{llllll}16.39 & 7.44 & 6.00 & 5.68 & 3.37 & 1.59\end{array}$

0.45

1.24

0.35

0.44

Gattendorfia evoluta Vöhringer, 1960; Oese, bed 30 (Pl. 2: 14-15)

MB.C. 5258.1

6.63

$\begin{array}{lllll}2.11 & 1.51 & 3.97 & 1.32 & 1.56\end{array}$

0.32

1.40

0.60

Paprothites ruzhencevi n. sp:; Hasselbach, bed 57 (PI. 1: 21-24)

$$
\begin{array}{lllll}
19.8 & 8.9 & 5.6 & 9.6 & 4.9 \\
15.5 & 8.4 & 4.8 & 7.7 &
\end{array}
$$

Paprothites dorsoplanus (Schmidt, 1924); Oese, bed 22 (PI. 2: 22-23)

$$
\begin{array}{lllll}
11.47 & 5.35 & 4.24 & 4.40 & 3.20
\end{array}
$$

1.92

0.47

1.26

0.38

0.20

Paprothites sp.; Hasselbach, bed 57 (Pl. 1: 17-18)

MB.C. 5240.10

$$
14.30
$$

$5.72 \quad 4.60$

$5.55 \quad 3.66 \quad 1.81$

0.40

1.24

0.39

0.20

Pseudarietites westfalicus Schmidt, 1924; Hasselbach. bed 49 (PI. 1: 5-6)

MB.C.5236.1

$$
\begin{array}{llll}
9.29 & 4.47 & 3.46 & 3.28
\end{array}
$$

Eocanites sp.; Hasselbach, bed 45 (Fig. 14J)

$\begin{array}{rrrr}\text { MB.C.5234.2 } & 36.04 & 8.99 & 10.19 \\ & 26.30 & 7.34 & 7.61 \\ 19.22 & 6.16 & 5.79 \\ & 13.92 & 4.92 & 4.52 \\ & 9.77 & 3.85 & 3.39 \\ & 6.67 & 2.79 & 1.97\end{array}$

$\begin{array}{rrr}18.25 & 9.74 & 1.88 \\ 12.90 & 7.08 & 1.87 \\ 8.91 & 5.30 & 1.91 \\ 6.01 & 4.15 & 2.03 \\ 4.41 & 3.10 & 2.15 \\ & & 1.83\end{array}$

0.25
0.28
0.32
0.35
0.39
0.42

0.88
0.97
1.06
1.09
1.14
1.41

0.51
0.49
0.46
0.43
0.45

0.04

0.07

0.08

0.08

0.09 